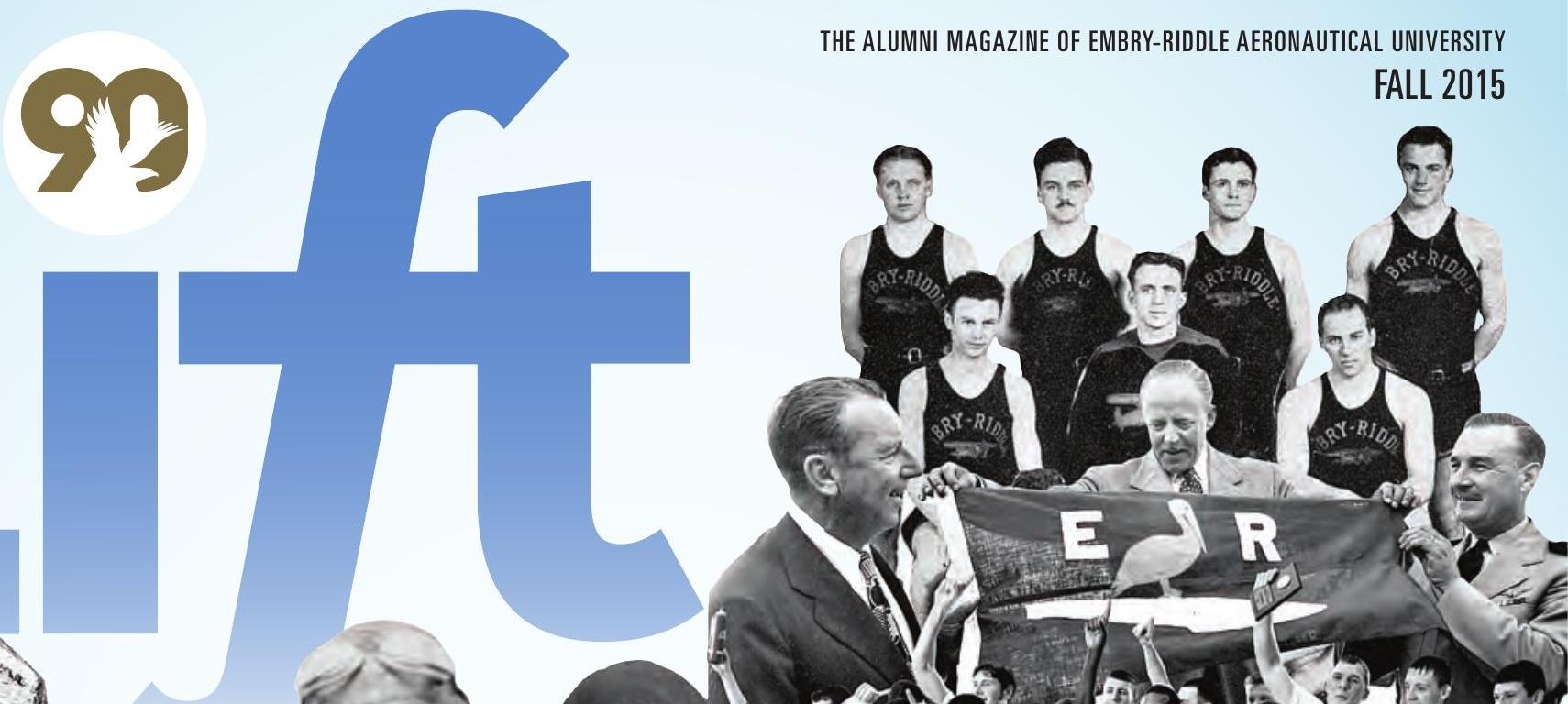
(IECOMO we to 1501 a. 1 .

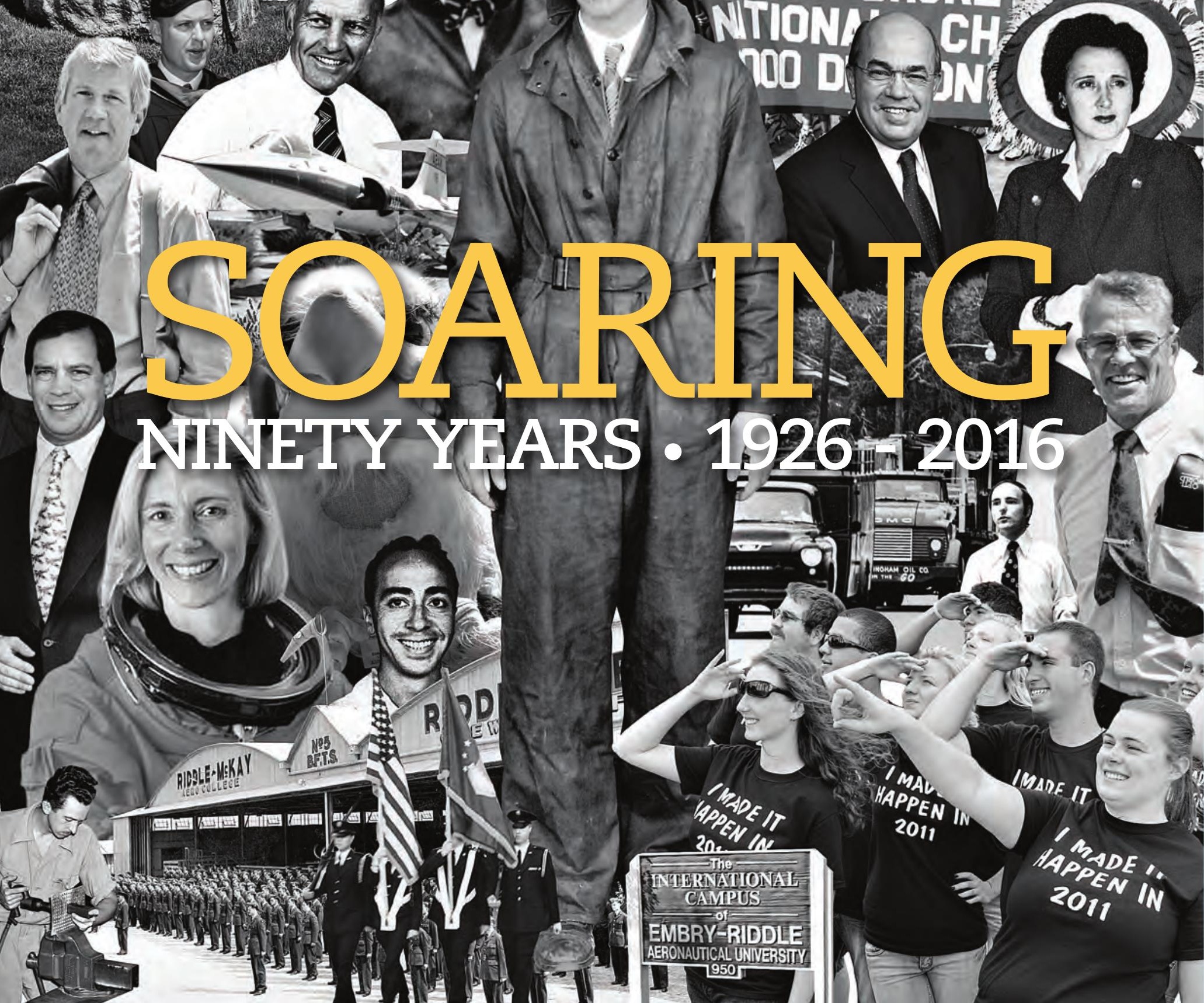




\section{FROM THE INTERIM PRESIDENT}

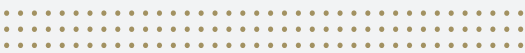

n,

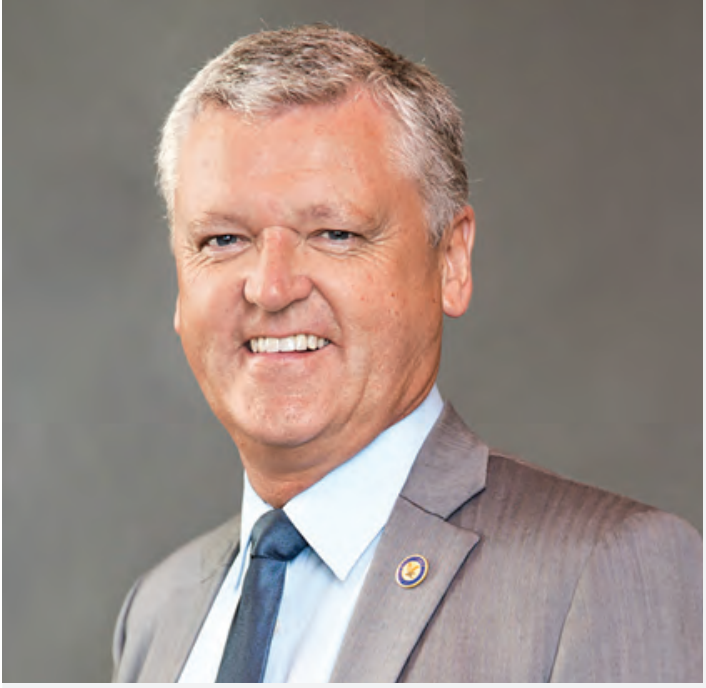

In this issue of Lift, we commemorate the approach of Embry-Riddle's 90th year as the world's leader in aviation and aerospace education and training.

In my several roles that include professor, associate dean, associate chancellor, associate provost, chancellor, chief operating officer and now interim president, I have had the fortune of serving Embry-Riddle's mission for 25 of those 90 years. In that time, as you'll read in this issue, Embry-Riddle has passed many milestones while making steady progress toward the strong position we enjoy today.

It is from that strong, hard-earned position that we look to our future-a future that will be defined by the "Opportunity of the Centennial."

Now, within a decade's reach of our 100th year, we have the perfect opportunity to envision-and ultimately arrive atwhere and what we aspire to be when that centennial arrives.

I believe that our progress in the next 10 years will be defined by how well we perform in four key areas:

- Financial strength. Diversifying our revenue streams through an increase in philanthropic investment and research activity will control our costs while expanding our ability to prepare students and provide solutions to industry;

- Leadership. Placing strong leaders at our campuses will reorient the President's Office, allowing it to align and act upon external partnership opportunities;

- Academics. Focusing on signature research areas, enhancing our most viable degree programs and providing enriched student-life opportunities will prepare students for a healthy and prosperous life, characterized by civic engagement, discovery, adaptability and lifelong learning;

- Globalization. Extending Embry-Riddle's reach in the key emerging aviation markets in Asia, Latin American and the Middle East will allow us to equip students with the professional and cultural skills they'll need to excel in today's more technologically interconnected, globally competitive industry.

My goal as interim president will be to ensure that we make substantial progress in these areas as we "plant the flag" for the next phase of our growth and development. As alumni, you will play a vital role in this progress. Your achievements in industry and contributions to your university will help determine what our university will be in its centennial year.

And, if the last 10 years are any indication of what's to come, we should expect to be extraordinary. I look forward to working with you as we begin this next great chapter in our university's history.

Sincerely,

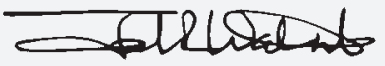

John R. Watret, Ph.D., FRAeS

INTERIM PRESIDENT

\section{Lift}

Volume 11, No. 2

Lift, the alumni magazine of Embry-Riddle Aeronautical University, is published twice annually (spring and fall).

Copyright () 2015

Embry-Riddle Aeronautical University

Florida/Arizona/Worldwide

600 S. Clyde Morris Blvd.

Daytona Beach, FL 3211

All rights reserved

Senior Vice President of External Relations and Chief Marketing Officer Bill Hampton ('98, '00, DB)

Senior Executive Director of Development

Christopher Lambert, J.D.

Executive Director of Alumni Relations

Bill Thompson ('87, PC)

Senior Editorial Director

Anthony Brown

Editor

Sara Withrow

Communications Specialists

Melanie Stawicki Azam

Alan Marcos Pinto Cesa

\section{CONTRIBUTORS}

Mike Carlson

Yoon Choi, Director of Annual Giving

Keith Deaton ('05, '12, DB), Director of Alumni Relations

Melanie Hanns, Director of University Communications

Molly Justice, Director of Communications, Embry-Riddle Worldwide

Trish Kabus, Creative Director

Jason Kadah, Communications Manager

Paula Kropp, Database Manager

Daryl LaBello, Multimedia Producer

Thomas S. "Sid" Mann III ('61, MC,

Non-degree)

David Massey, Multimedia Producer

Kevin Montgomery, University Archivist

Edmund Odartey ('04, '10, DB), Senio

Director of Alumni Relations, Daytona Beach Bob Score, Media Production Coordinato

Published by McMURRY/TMG, LLC

Senior Content Editor

Tom Weede

Creative Director

Adele Mulford

Senior Art Director

Tamara Kopper

Production Manager

Jenny Babich

Production Technology Specialist

Sonia Fitzgerald

Account Manager

Mary Jane Sweetland

Embry-Riddle Aeronautical University is an Affirmative Action/Equal Opportunity Employer and does not discriminate on the basis of race, color, religion, gender, age, national origin, handicap, veteran's status or sexual orientation.

Nonprofit identification: 59-0936101

Change address, unsubscribe or email the editor at liftmag@erau.edu.

3 PRINTEd on recycled Paper 


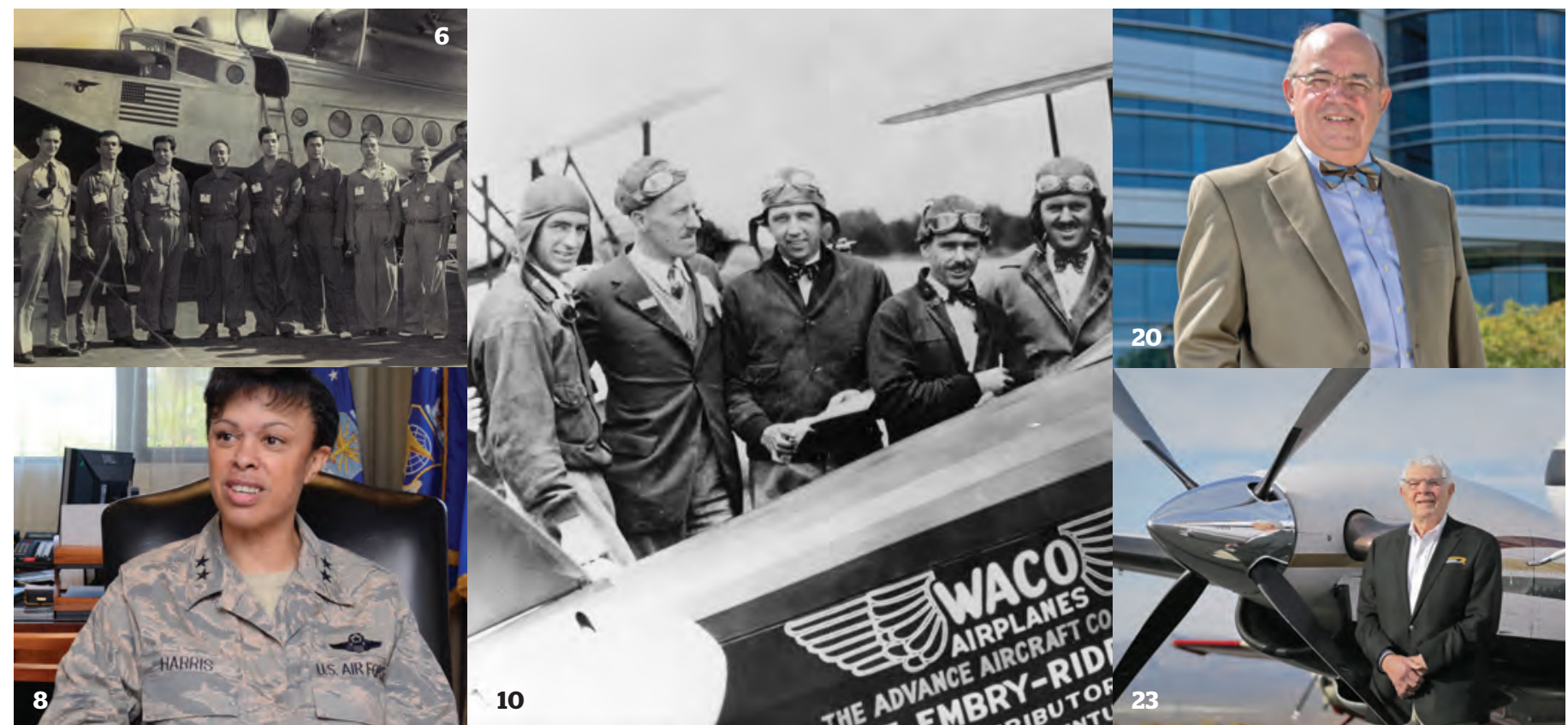

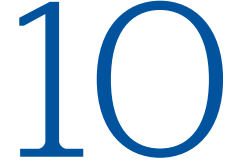

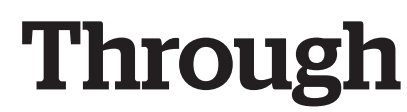

\section{the Decades}

A look back at moments in Embry-Riddle history
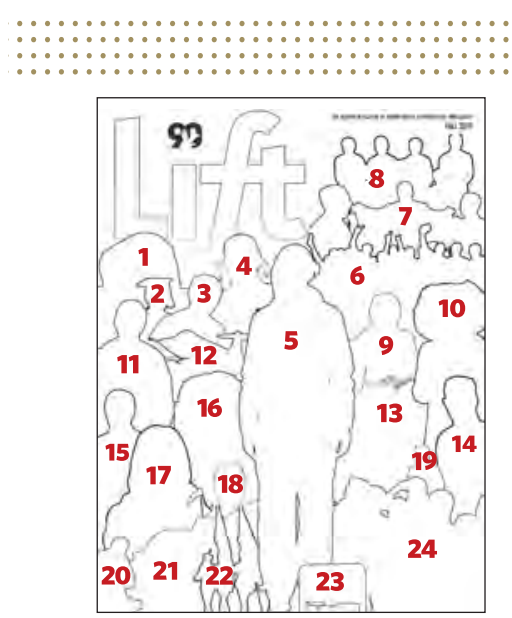

IN OTHER WORDS

\section{Miami Memories}

Thomas S. "Sid" Mann III ('61, MC, Non-degree), reminisces about his Embry-Riddle experiences WINGS OF LEGACY

6 The Latin American Department

Centenarian "Zalo" Lopez-Garzón ('42, MC) was one of the first international students at EmbryRiddle's School of Aviation

\section{FLIGHT PATH}

\section{Trailblazer}

Maj. Gen. Stayce Harris

(' $87, W W$ ) is proud to walk the path set by some of her aviation heroes

$\begin{array}{ll}\text { ON THE COVER: } & \text { 7. John McKay, Left, and Miami } \\ \text { 1. Spirit Rock (Prescott Campus) } & \text { Seaplane Base Banner } \\ \text { 2. Norman Knight ('90, PC) } & \text { 8. Flying Basketball Squad, 1928 } \\ \text { 3. Jack Hunt } & \text { 9. John P. Johnson } \\ \text { 4. T. Higbee Embry } & \text { 10. Isabel Mckay } \\ \text { 5. John Paul Riddle } & \text { 11. George H. Ebbs } \\ \text { 6. 2000 National Championship } & \text { 12. Lockheed F-104 Starfighter No. } \\ \text { (Daytona Beach Campus) } & \text { 811 (Prescott Campus) }\end{array}$

SPECIAL TO THIS ISSUE

\section{Onward and Upward}

At the end of a decade of leadership, President Emeritus John P. Johnson looks back on an era of innovation and discovery

\section{GIVING TO EMBRY-RIDDLE}

\section{Legacy of Learning}

James Raisbeck and Raisbeck Engineering endow chair at Prescott Campus

\section{ALUMNI IN ACTION}

\section{Giving History Its Place}

Phil Metz ('81, DB) helps preserve Embry-Riddle's past for future generations

13. Operation Bootstrap
14. Kenneth Tallman
15. Steve Sliwa
16. Ernie the Eagle
17. Susan L. Still-Kilrain ('82, 0B)
18. 'Zalo' Lopez-Garzón
19. Professor John Jenkins
(Prescott Campus)

20. Machinist student, circa 1940s 21. Riddle Field, Clewiston, Fla.

22. Det. 157 Air Force RotC (Daytona Beach Campus) 23. International Campus Sign 24. 2011 Graduating Class-100,000 Alumni Milestone

\section{Chatter}

News and notes

from the world of

Embry-Riddle

\section{Feedback}

Embry-Riddle

alumni and friends offer comments and opinions

\section{Alumni News}

A message from the

Alumni Association, upcoming events and more
32 Class Notes

Find out what your fellow alumni are up to now

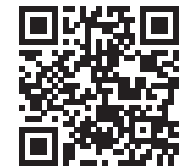

READ LIFT ONLINE! 
NEWS \& NOTES FROM THE WORLD OF EMBRY-RIDDLE

\section{CHATTER}

\section{ALTIMETER: \\ HIGH POINTS AT \\ EMBRY-RIDDLE}

Prescott Campus' observatory was named No. 8 on College Rank.net's list of the nation's Top 35 Best College Astronomy Observatories.

Head Coach Steve Ridder was named Sun Conference Coach of the Year. And, DeForest Carter ('15, DB) was named Sun Conference Men's Basketball Player of the Year. The team had its best regular season in program history (35-2 overall).

\section{The Daytona Beach Athletics} program earned its 16 th consecutive Sun Conference Commissioners Cup, recognizing the best overall program in the league.

\section{The Prescott Golden Eagles} flight team placed third overall and the Daytona Beach Eagles flight team tied for fifth at the National Intercollegiate Flying Association Safety and Flight Evaluation Conference.

\section{Prescott Campus' Phi Beta} Lambda (PBL) Business Club earned 61 first-place awards at the 2015 PBL Arizona Leadership Conference, outpacing its nearest competitor by 46 first-place awards.

The 2015 PayScale College ROI Report ranked Embry-Riddle's Prescott Campus No. 1 in Arizona and the Daytona Beach Campus No. 2 in Florida for best return on investment for graduates.

Professor William Engblom and a research team from the Daytona Beach Campus' College of Engineering were awarded a $\$ 100,000$ Phase I NASA Innovative Advanced Concepts grant.

\section{Embry-Riddle president retires after nearly 12 years of service}

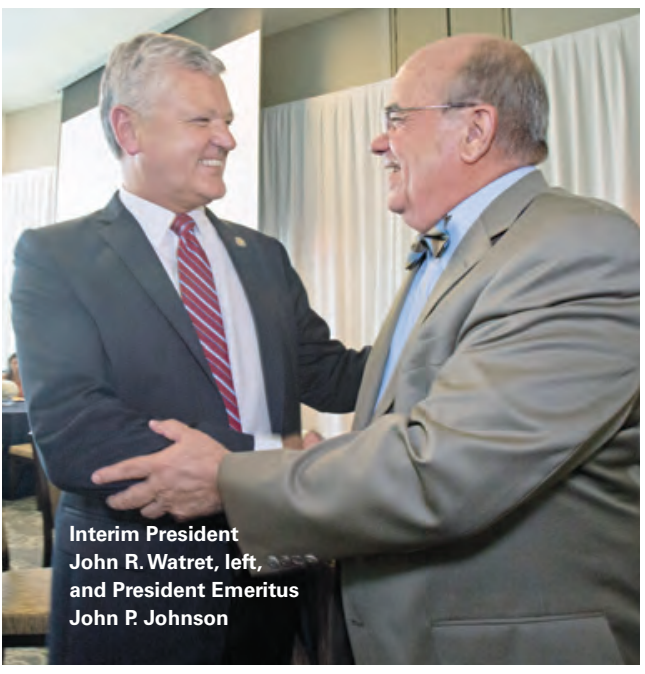

A fter more than a decade of service to the university, Embry-Riddle President and CEO John P. Johnson announced his retirement, effective May 31.

In 2006, Johnson became EmbryRiddle's fifth university president, after serving as interim president and provost. Under his guidance, the university added dozens of degree programs, as well as the nation's first doctorate in aviation and first College of Security and Intelligence, and the world's first commercial space operations degree. (See related article on page 20.)

Johnson was named president emeritus in recognition of his contributions to the university. He will continue to act as a university ambassador and a link to the community. "I consider Embry-Riddle the pinnacle of my 46-year career," Johnson says.

\section{Interim President Named}

Embry-Riddle's Senior Vice President and Chief Operating Officer John R. Watret was named interim president, effective June 1. Watret, who has been with Embry-Riddle since 1989, is a Fellow of the Royal Aeronautical Society and executive committee member of the Global Aerospace Summit Advisory Board. He is also an appointed member of the FAA Aviation Aerospace Workforce Committee and the University of Florida Online Advisory Board.

He holds a Ph.D. and a master's in mathematics, both from Texas A\&M University, and a bachelor's with honors from HeriotWatt University in Edinburgh, Scotland. A professor and pilot, he along with wife Elizabeth and daughter Sophie are long-time residents of Ormond Beach, Fla. -Melanie Hanns

\section{Embry-Riddle Prescott Athletics Scores Commissioner's Cup}

For the first time in school history, the Embry-Riddle Prescott Eagles topped off a successful athletics year by winning the 2014-15 Cal Pac Conference Commissioner's Cup of the National Association of Intercollegiate Athletics (NAIA).

The Commissioner's Cup is awarded to the institution that accumulated the most points in the previous school year. Points are awarded based on conference championship finishes, including post-season tournaments.

Prescott Campus student-athletes also lead academically. This year, 17 student-athletes carrying a minimum grade point average of 3.5 (on a 4.0 scale) were named Daktronics-NAIA Scholar-Athletes.

"We are so proud of the fact that our student-athletes are dominant both on the field and in the classroom," says Embry-Riddle Prescott Chancellor Frank Ayers.

Embry-Riddle Prescott's Athletics Department continues to grow, with men's basketball launching this fall and women's basketball coming in fall 2016. - Jason Kadah

\section{WATCH}

The retirement celebration video dedicated to President Emeritus John P. Johnson: http://youtu.be/ nc09nsmZTwc. View photos of the retirement party: http://on.fb. me/1JOIOHh

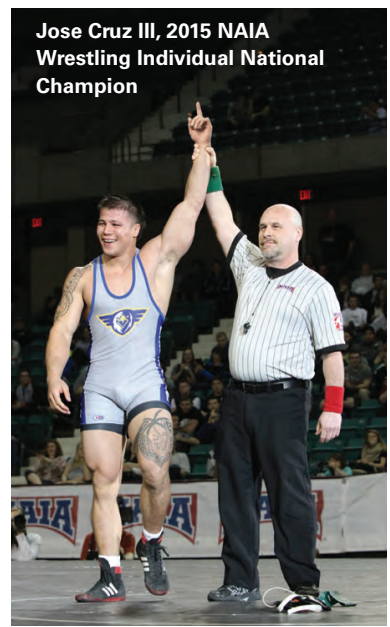




\section{Students Take Clean Energy Competition to a New Level}

E mbry-Riddle students are diving deep into diesel emission technology and earning accolades for it. In April, a multidisciplinary team of four engineering students enrolled in the Clean Energy Systems track at the Daytona Beach Campus received a $\$ 75,000$ grant from the Environmental Protection Agency to bring its diesel emissions test stand to a level of realworld application.

Marc Compere, associate professor of mechanical engineering, says the test stand will help automobile manufacturers test real-world emissions from hybrid diesel-electric engines, which he believes will be necessary to meet strict fuel economy standards in the near future. Emissions are a challenge for diesel hybrids, which require selective catalyst reduction (SCR) systems to meet their targets.

"We're partnering with the engineering physics department to apply advanced, nonlinear control techniques to improve SCR performance," Compere says.

The team won phase one of the EPA's People, Prosperity and the Planet (P3) competition in 2014 with its test stand design, earning a $\$ 15,000$ award. The team used those funds to improve the design for this year's follow-up competition.

\section{ECOCAR 3}

Another clean energy student project at the Daytona Beach Campus, the EcoEagles is one of 16 university teams across North America participating in EcoCAR 3, the latest Department of Energy Advanced Vehicle Technology Competition.

“EcoCAR 3 provides students with a unique opportunity to gain hands-on experience. The team runs like a company: The students get a taste of the real world while handling the types of projects that they will see much later in their careers," says Patrick Currier, assistant professor of mechanical engineering and the team's lead faculty adviser.

The EcoEagles have competed in similar contests since 2008. Later this year, the team will receive a stock 2016 Chevrolet Camaro donated by General Motors for the competition. Their task: to redesign the car into a hybrid-electric vehicle that will reduce environmental impact, while maintaining its expected muscle car look and performance.

It will use one gas-powered, fourcylinder engine and two electric motors, says Calvin Baker, an Embry-Riddle student and EcoCAR 3 communications manager.

For more: EcoEagles.org. -Alan Marcos Pinto Cesar

\section{Worldwide Campus gains contract for military education in South Korea, Japan}

Embry-Riddle's Worldwide Campus started offering face-toface aviation degree programs to members of the U.S. military stationed at overseas Pacific locations in August, with authorization from a Department of Defense contract.
The contract allows EmbryRiddle to provide undergraduate and graduate degree programs to service members and civilians on U.S. military installations within the Pacific Command's overseas locations.

Bob Walton, executive director of campus operations for Embry-Riddle's Worldwide Campus, says, "This new award helps us expand our global reach by offering degree programs to the thousands of personnel assigned to this region." -Molly Justice
ALtimeter (continued)

Daytona Beach studentathletes Zac Grotz and Tyler Cyr were drafted by the Houston Astros and the San Francisco Giants, respectively, during the 2015 Major League Baseball Draft.

Embry-Riddle and the Alliance for System Safety of UAS through Research Excellence were selected by the Federal Aviation Administration as the nation's new Center of Excellence in Unmanned Aircraft Systems. http://bit. Iy/1G3Hm01

BY THE NUMBERS

\section{Where are they now? Topstates for Embry-Riddle Eagles}

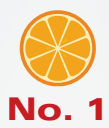

Florida $(18,245)$

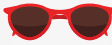

No. 2

California $(9,166)$

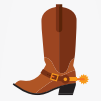

No. 3

Texas $(8,949)$

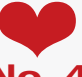

No. 4

Virginia $(5,656)$

No. 5

Georgia $(5,535)$

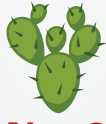

No. 6

Arizona $(4,885)$

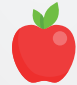

No. 7

Washington $(4,006)$

SOURCE: Embry-Riddle Alumni Database 


\section{FEEDBACK}

\section{FROM THE EDITOR}

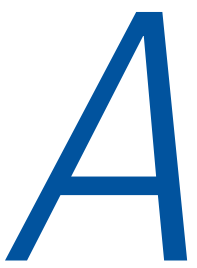

s Embry-Riddle celebrates its 90th

anniversary, Lift celebrates its first

decade. Born in the fall of 2005

as a 28-page, biannual magazine

designed to keep alumni connected to their alma mater and

aware of opportunities to support its growth, Lift quickly became the university's flagship publication. Today, your alumni magazine is 10 pages

larger, and is mailed to 60,000 subscribers. You can also read it online or on your mobile device. And, this August-to coincide with its first doubledigit anniversary, Lift launched its own dedicated website: lift.erau.edu. As always, let us know what you think: liftmag @erau.edu.

-SARA WITHROW, EDITOR

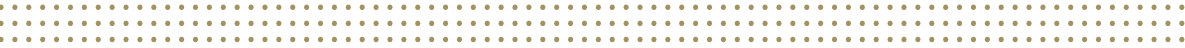

\section{Veteran Roots Run Deep [Wings of Legacy, Spring 2015] Strikes a Chord}

\section{Article Hits Home}

The comments made in the article were accurate. I started my education at EmbryRiddle in Miami in January 1961. My success and rewards in life are all due to the well-rounded education that I received at Riddle. Who would have thought that when I received my B.S. in Aeronautical Engineering, 33 years later I would retire from a quality assurance management position with a major electronic defense contractor!

David L. Archibald ('68, DB)

B.S. Aeronautical Engineering

\section{Veteran Actions Questioned}

The Vietnam War was a divisive issue in the '60s and '70s and remains so today. However, there were references in this article that I found unsettling. Specifically, the anecdote about a student who was assaulted by veterans who "gave him a 'very nice' haircut."

An act of violence against a student is never justified, and it is not something that should be used in an article to contrast differences in political opinions. It is possible to be supportive of the U.S. military and still object to a particular war or military action. Attacking a student does not demonstrate "a sense of patriotism." It demonstrates a fundamental disrespect for the views of others, and it shows contempt for democracy.

In the article, Professor Pete Vosbury ('69, DB) mentions a vet who responded to criticism from a fellow student by saying, "indeed, he was trained to kill, but ... his training was used to protect our country and [the student's] freedoms." If your response to people who burn flags or who have long hair and earrings is that you fought so that they could have the freedom to do such things, then don't complain when they do.

Robert Scott Roper ('87, DB)

B.S. Aeronautical Science

EDITOR'S NOTE: To clarify: Wings of Legacy articles are not meant to condone or condemn, but rather to provide an accurate representation of the events and culture of our university's past. Under no circumstances does the university approve of the described incident, but it does represent the pro-veteran sentiment on campus at the time. Your letter provides a healthy dose of perspective and an object lesson for a nation that still grapples with supporting its veterans in the wake of war. Thank you.

\section{Veteran Pride}

My educational background was very unique from my classmates. I graduated in 1964 from Tennessee Agricultural \& Industrial State University in Nashville, Tenn., with a B.S. in Technical Aeronautics, before enlisting in the U.S. Army. In 1967, I enrolled in Embry-Riddle's aircraft maintenance program. There were more than 20 students in my class; 19 were vets from the Army, Air Force and Navy.

During our time in school a lot of social milestones took place. Dr. Martin L. King Jr. was assassinated, and George Wallace ran for president of the United States. We all had our opinions on the current events, but our heads were cool and we kept our focus on our goals.

After graduating with my A\&P and an associate degree, I took a job at McDonnell Douglas Corporation in St. Louis, Mo. Embry-Riddle was the basis for my educational foundation in the aerospace industry, and, in 1987, I completed a master's degree.

This Negro veteran received a great deal of preparation from Embry-Riddle, and I am thankful and blessed. Hats off to a job well done, and, thanks, Embry-Riddle Aeronautical University.

Glenn A. Ball ('69, DB; '87, WW) A.S. Aviation Maintenance Technology M.S. Aviation Management

\section{'Eagle'-Eyed Alumnus}

I just got your latest issue of Lift. I noted on page 1, that Scott Yoak "flies a North American P-15 Mustang for a living." I've never heard of a P-15, but I have heard of a P-51. I edit Pterogram, the newsletter of the Coast Guard Aviation Association. I'm very diligent about proofreading. Catching typos makes my day. Keep up the great work.

Retired U.S. Coast Guard Capt. Stephen

Goldhammer ('73, WW)

B.S. Aeronautical Science

\section{TALK TO US}

We invite your feedback on Lift content or topics related to the university. Letters may be edited for style, length and clarity. Submission does not guarantee publication.

EMAIL: liftmag@erau.edu

WRITE: Lift Editor ERAU Alumni Relations 600 S. Clyde Morris Blvd. Daytona Beach, FL 32114 


\section{BY THOMAS S. "SID" MANN III ('61, MC, NON-DEGREE)}

It was October 1961, the night before my graduation from Embry-Riddle's Airframe \& Powerplant (A\&P) Technician course in Miami. Several classmates thought we should leave a class memento, so we assembled a life-sized, stuffed dummy with jeans, shirt and a hat, dangling a few beer cans tied on with string, and it was hoisted up the flagpole facing 27th Avenue. Then Embry-Riddle President Isabel McKay might well have been the first person to see it from her penthouse in the Aviation Building the next morning. The "several classmates" quickly dissolved into one other student and me, and we were promptly invited to Mrs. McKay's residence. We could see our young lives flash before us, until she accepted our apology and allowed us to graduate.

I came to Embry-Riddle 16 months earlier from Massachusetts. After a month in the dorm, I rented a house with two students: one from Greece and the other from Lebanon. About 15 percent of our class were international students. My saddest time at Riddle was when my Lebanese friend died in a Miami hospital from a misdiagnosed ruptured appendix.

Every month or so we would have mixers. Some were straight-laced dancing events at Barry College for Women in Miami Shores, now Barry University. We mixed better with the students at Miami's Jackson Memorial Hospital School of Nursing. They would host us on the flat hospital roof with a record player for dancing and the romantic Miami skyline as a backdrop.

Crandon Park at nearby Biscayne Key had a segregated beach at the time. Some weekends there were peaceful "swimins" and it would make the local headlines. During that time, I had a black student friend, Sidney Meyers, from Jamaica. One day, six to eight of us went up to Hallandale Beach for a swim. Boys being boys, Sidney and I started wrestling on the sand. After a few minutes, he had me well pinned and I gave up. As I stood up, I noticed a few other people had gathered around, perhaps thinking it was a racial incident. Of course it was not, just two friends horsing around.

One night, a classmate, Harold Hernandez, and I went to the Miami International Airport (MIA) terminal and rang the tower buzzer. A voice over the speaker responded, and we said we were Embry-Riddle students and wanted to come up and look around. We were acknowledged, "Come on up," and buzzed in, and we climbed the stairs to witness the spectacle of MIA's tower operation at night. We were in heaven.

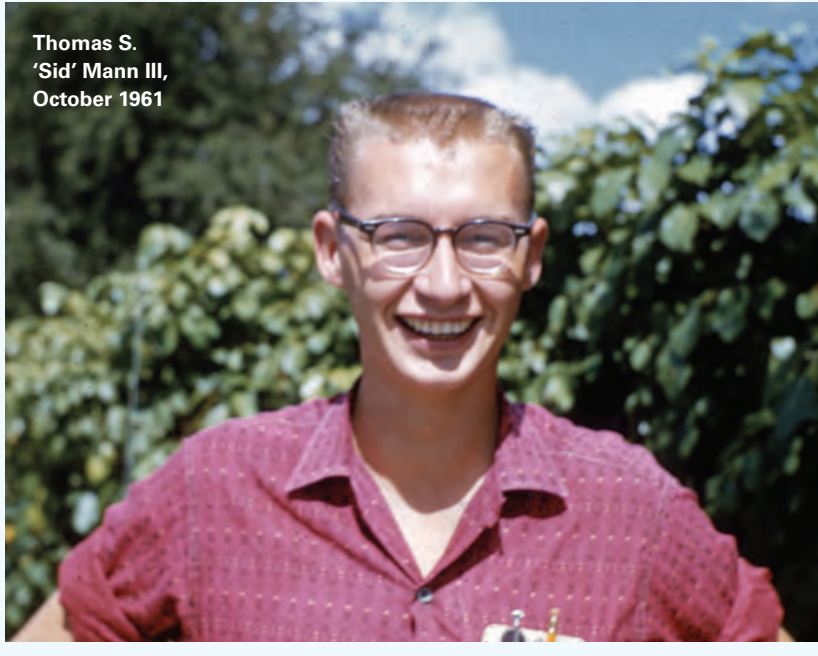

After graduating, Harold and I got jobs at Avex, a Fixed Base Operator (FBO) at the original Tamiami Airport. On our first day, the manager led us out the back door where a Twin Beech was sitting on the grass. He said, "We have to paint this airplane; you guys have to sand it." Our introduction to the world of aviation mechanics began with hand sanding a Twin Beech for about a week or so.

My career at the FBO lasted two months at most. I had matured enough to recognize that family was important, so I returned to Massachusetts to do logging and sawmill work.

At Embry-Riddle I came to appreciate the order of magnitude difference in aviation mechanic disciplines, compared with the work I had completed in shop class at high school, or the maintenance on my 1928 Model A Ford. I learned that study and perseverance are needed to accomplish one's goals. The vehicles and power equipment used in harvesting, drying, milling and selling lumber need proper care as well, and after completing my A\&P, I had new confidence in my skills. To this day, I call into use bits of knowledge that I absorbed at Embry-Riddle. I sure did get my money's worth! I eventually became manager of the family lumber business, which my son now runs.

All things change, and we with time, but my Embry-Riddle experience was a very valuable asset in understanding life, people and myself over the years.

EDITOR'S NoTE: Mann resides in Sarasota, Fla., with his wife, Sandra Trivino. He has three adult sons. For the past eight years he has worked part time as a building supervisor.

SEND US YOUR STORY In Other Words gives you the opportunity to share your industry-related or personal perspective with Lift readers. Email submissions/proposals to liftmag@erau.edu. 


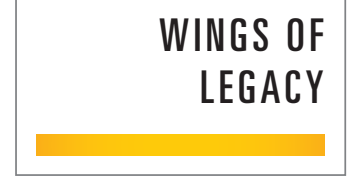

\section{The Latin American}

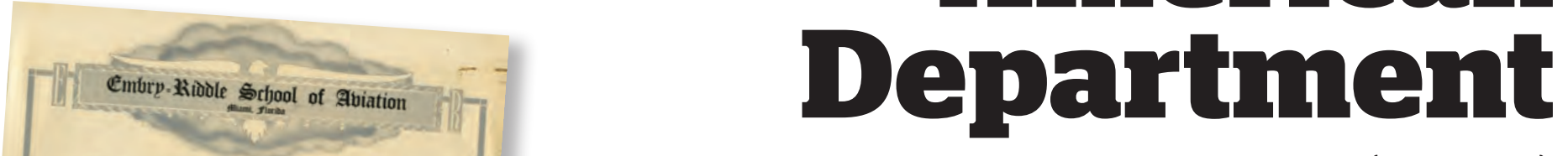

Centenarian 'Zalo' Lopez-Garzón ('42, MC)

This Certifies Thur Bonzalo evuario Iopez $y$ Garzon

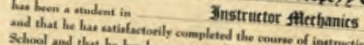

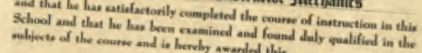

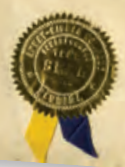

DIPLOMA

was one of the first international students at Embry-Riddle's School of Aviation

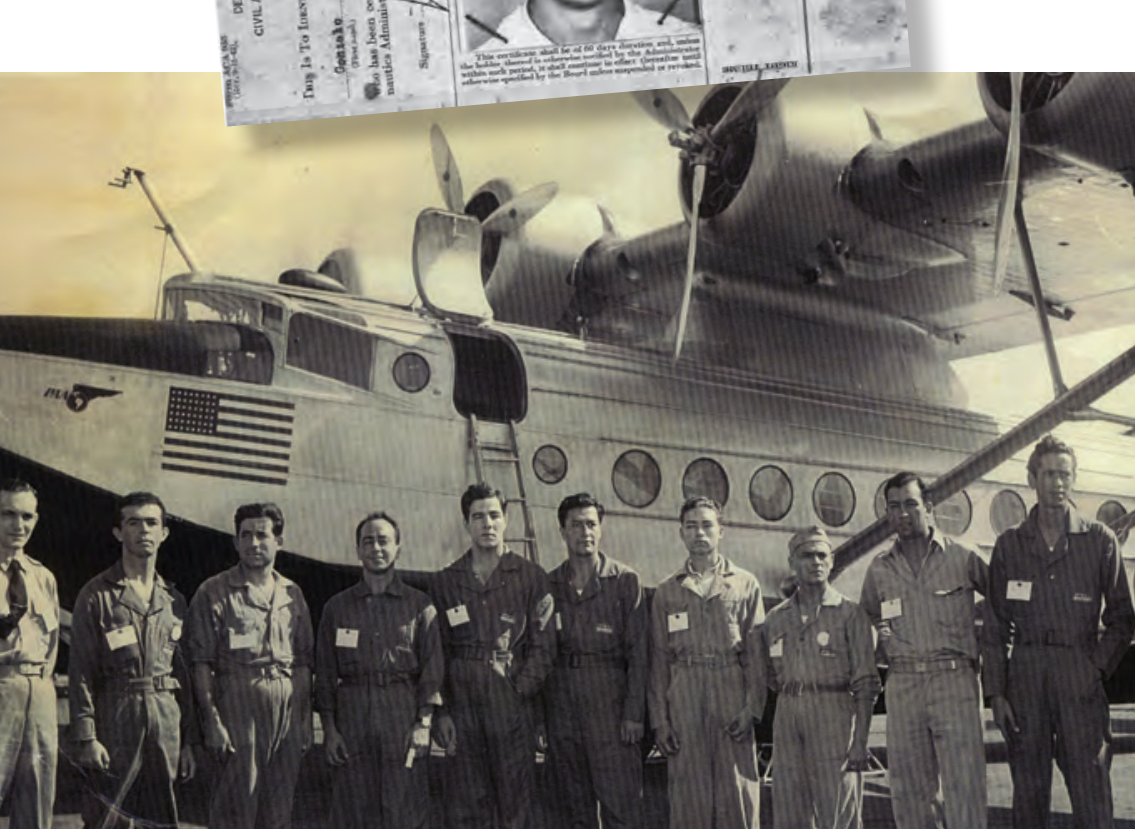

BY ALAN MARCOS PINTO CESAR

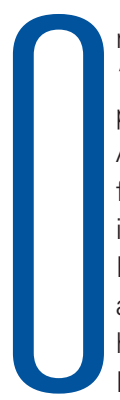

$\mathrm{n}$ the first Sunday in December 1941, Gonzalo "Zalo" Lopez-Garzón ('42, MC) was hosting a party at a park near his home in Buenos Aires, Argentina. The celebration, complete with music from his portable radio, was to mark his upcoming departure for the United States to study at Embry-Riddle. Suddenly, from his radio came a surprise announcement. "They said Japan has attacked the United States at Pearl Harbor," Lopez-Garzón recalls.
The recipient of an Inter-American Aviation Training Program (IAATP) scholarship, Lopez-Garzón immediately feared the worst. "That was the end of the picnic, the end of my aspirations. I went to the embassy and I asked, 'Will this cancel my scholarship?' and they said, 'No, everything goes on in war.'"

Lopez-Garzón, who celebrated his 100th birthday in February and is believed to be Embry-Riddle's oldest living alumnus, was one of 526 students representing countries from all over Central and South America who came to Embry-Riddle in 1941-42 under the federally funded IAATP. Though multiple schools were involved in the program, he picked Embry-Riddle. "The reason I insisted on going to this school in Miami is that the Embry-Riddle School of Aviation was the first international coming together of people from so many countries for the service of aeronautics in the United States," he says.

Embry-Riddle Archivist Kevin Montgomery confirms Lopez-Garzón's recollection. Students participating in the IAATP were the first recorded international students to attend Embry-Riddle. Contracted through the Civil Aeronautics Administration and the U.S. State Department, the program created a new education section at the EmbryRiddle Technical School: the Latin American Department. The new department provided a dual education program training both students from South America and U.S. citizens who planned to seek jobs in South America. The students learned about all aspects of the ground phase of aviation, including power plants, welding, sheet metal, instruments and radio. The scholarship provided 2,300 hours of training over a 16-month term.

\section{International Yearbook}

It was a dream come true for Lopez-Garzón. The native Argentinian had been interested in aviation technology since he was a child, and he adored American culture, too. A gregarious student, he took it upon himself to create the first-known, student-produced Embry-Riddle class yearbook. "I had a book and at the end of the courses I asked 
everyone from my core of students for a picture, and everyone wrote something about our friendship," he says. He recently donated the leather-bound book to the Embry-Riddle archives as a memorial of its first international students.

"The notion of internationality, in my estimation it started right there. Embry-Riddle became an international school, but it started with us," says Lopez-Garzón. "I felt that one day these students should be recognized as the origin of the internationality of the university."

Dean Emeritus Bob Rockett, who led the creation of the university archives during his 35-year tenure at Embry-Riddle, says the wartime training of students from other countries helped put Embry-Riddle on the map and was a significant milestone in the life of what would become the world's largest aviation university. "Zalo was enrolled in Embry-Riddle during the most important years of our history. The training of international students during the war took us from a little for-profit corporation into the university that we are today, and the people who built that foundation came from all over the world," Rockett says.

\section{Career Switch}

Lopez-Garzón received his diploma in Instructor Mechanics on May 7, 1943. He returned to Argentina in December of that year, after completing an additional six months of on-the-job training in instrumentation repair at Embry-Riddle. Soon after taking a job in the Airframe and Engines Division of the Dirección General del Material Aeronautíco, he was appointed to lead the Instruments Department. In 1956, he began teaching aeronautical instrumentation classes at the National School of Aeronautics in Argentina.

In addition to aviation, Lopez-Garzón had a penchant for interior design. When an opportunity arose in Miami for him to showcase his design skills, he took a leap of faith. "This design exhibition in Miami invited designers from different countries to come. I participated in the exhibition, and I won with a portable bar that I designed. From there on I was very successful," he says.

Upon discovering that interior design was his "true calling," he pursued it with a passion. His proudest accomplishment was to work with Maurice Gusman, a Miami philanthropist who chose LopezGarzón to design his Key Biscayne condominium. Lopez-Garzón's work became renowned internationally, as well. One of his favorite overseas projects was a man-

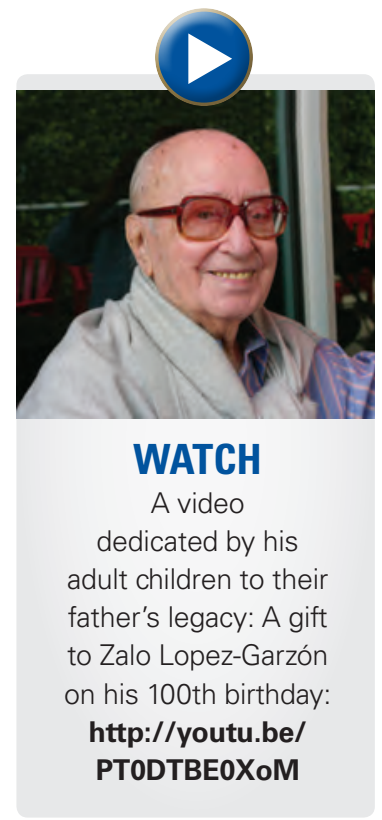
sion built on Lake Maracaibo in Venezuela.

His achievements in the field earned him a lifetime membership to the American Society of Interior Designers. In 1972, he retired and took up another hobby: travelling with his wife, Ofelia, now deceased. "We traveled to every part of the world except Asia. The farthest east we went was Egypt. The best part of my life was to be able to travel," he says.

Lopez-Garzón celebrated his 100th birthday on Feb. 23, 2015, almost 72 years after graduating from Embry-Riddle. "My brother lived to 102 years old. Longevity runs in my family," he says.

EDITOR'S NOTE: Wings of Legacy: The History of Embry-Riddle Aeronautical University (2010), by Alan R. Bender and Stephen G. Craft, was used as a reference for this article.
MYSTERY HISTORY CONTEST

What were

two popular

names for the

Embry-Riddle

Aviation Building,

which housed

the School

of Aviation

Technical School

in Miami?

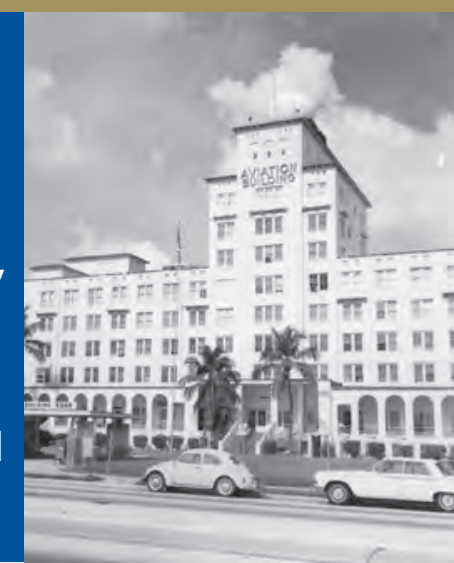

Are you an Embry-Riddle history buff? Then here's your chance to show us your stuff! Enter our Mystery History Contest for a chance to win a copy of Forever an Eagle: Embry-Riddle Aeronautical University - $A$ Pictorial History.

TO WIN: Search the University Archives online (erau.edu/about/archives) for the correct answer. Send your response to the email address on the archives webpage and your name will be entered into a random drawing held after Sept. 30.

Tarun Patel ('07, WW) of New Jersey is the winner of the spring 2015 Mystery History Contest. Patel correctly identified retired Maj. Gen. Donald J. Strait (HonDoc '86; '42, MC, Non-degree) as an Embry-Riddle alumnus who is also a flying ace. Strait did his basic flight training in the P-17 at Embry-Riddle Field in Union, Tenn. He went on to complete two combat tours and 122 missions in the P-47 and P-51 during World War II. He was the leading ace of the 356th Fighter Group with 13 1/2 victories. In 1989, he was inducted into the New Jersey Aviation Hall of Fame. Another alumnus/flying ace is the late Norman "Bud" Fortier ('43, MC, Non-degree), who trained at Embry-Riddle's Dorr Field.

Embry-Riddle's Archives department is dedicated to preserving the memories and artifacts belonging to the university's rich history.

Explore Embry-Riddle's past at erau.edu/about/archives. 


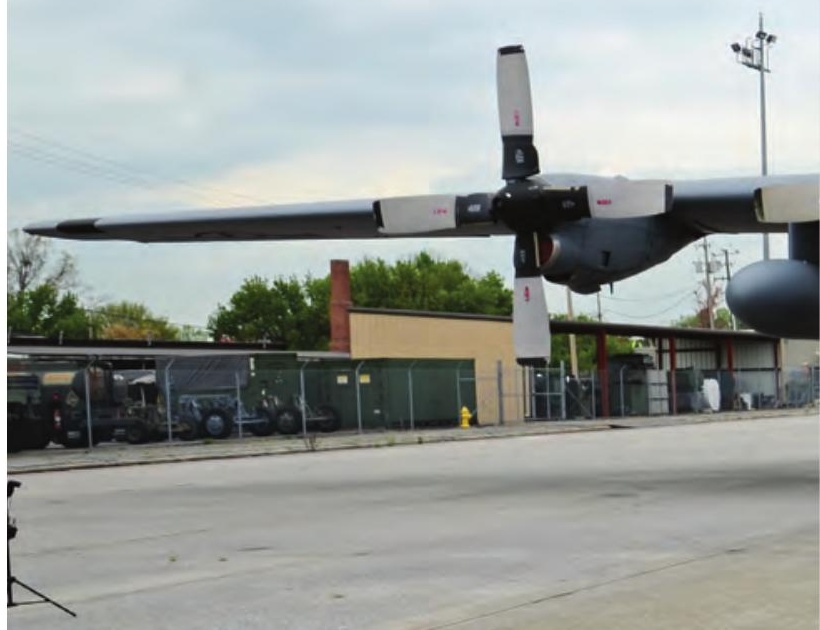

\section{Maj. Gen. Stayce Harris ('87, WW) of the Air Force Reserve is proud to walk the path set by some of her aviation heroes}

\section{BY MIKE CARLSON}

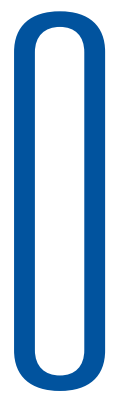

ne look at the resume of Maj. Gen. Stayce Harris ('87, WW) and it's easy to assume that a career as a military pilot was predestined. The daughter of an Air Force technical sergeant, she grew up moving across the United States every few years and even spent a handful of tours living overseas. In high school she began to plot her own career in the Air Force and was awarded an Air Force ROTC scholarship attending the University of Southern California.

But in her freshman year, an ROTC instructor encouraged her to compete for a scholarship for undergraduate pilot training. The opportunity was a revelation for her. Until then, she had assumed a career as an engineer would be her role in the Air Force, but here was an avenue to travel the world, one of her life's passions, and as the pilot.

"It was an 'aha' moment because this was the first time the Air Force was allowing women in college to apply for pilot training," says Harris. "They had already chosen women on active duty to receive the training but we were the first wave of women graduating from college [to participate]. I competed for that scholarship and was accepted. And that started my life becoming a pilot."

\section{Female Aviators}

Women and minorities are historically underrepresented among military pilots. When Harris began her flight training in the early 1980s, she was one of the first African-American female pilots her instructors met. This experience was not without its challenges.

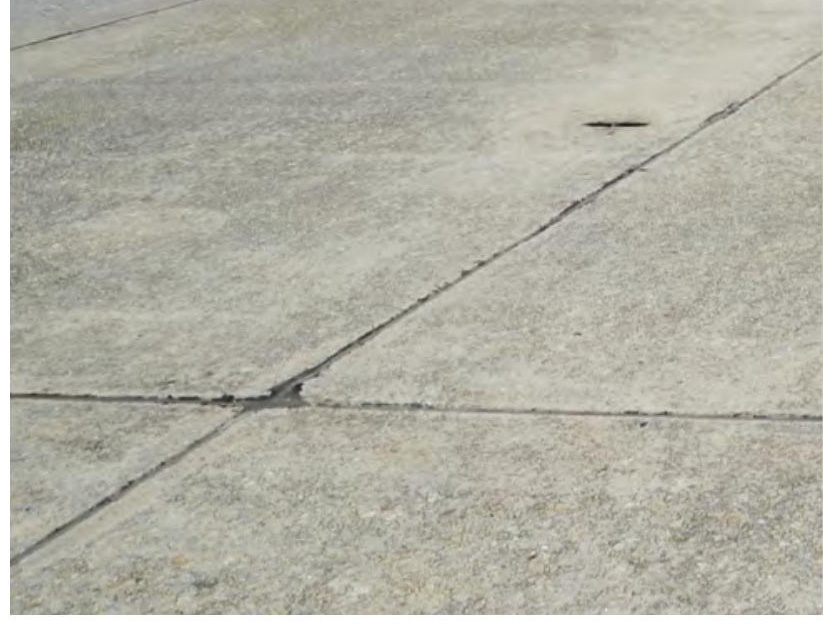

Retired Brig. Gen. Steven Roser, who became a mentor to Harris after she served under his command in the 14th Military Airlift Squadron, says there's an "institutional bias" that can creep into any organization. When a candidate doesn't look like someone's preconceived idea of a leader, it can be challenging for that person to find acceptance, he explains. Without a precedent of female AfricanAmerican aviators, Harris was forced to create her own beachhead within the Air Force.

"A lot of the life lessons that I have had, I learned them early," she says. "And I am grateful. You have to trust in yourself and be persistent in your goals no matter what others may think."

Since her undergraduate degree was in engineering, Harris wanted to broaden her aviation aperture and learn more than just piloting. She enrolled in a master's of aviation management program at the Embry-Riddle Campus at Norton Air Force Base, Calif. Her experience at Embry-Riddle led to Harris developing an important part of her persona and what has become a defining facet of her career: teaching and mentoring others.

"One of the greatest benefits was that I was able to become an adjunct professor at Embry-Riddle. I could give back some of the knowledge and experiences to those earning their bachelor's degrees," she says. "Embry-Riddle's giving me that opportunity was unique. I really enjoyed that experience." 


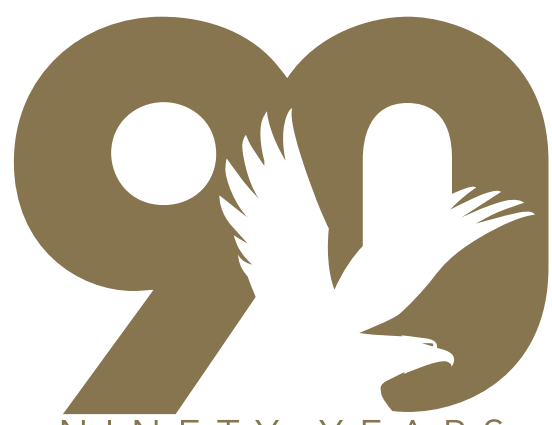

NINETY Y E A R S $1926-2016$

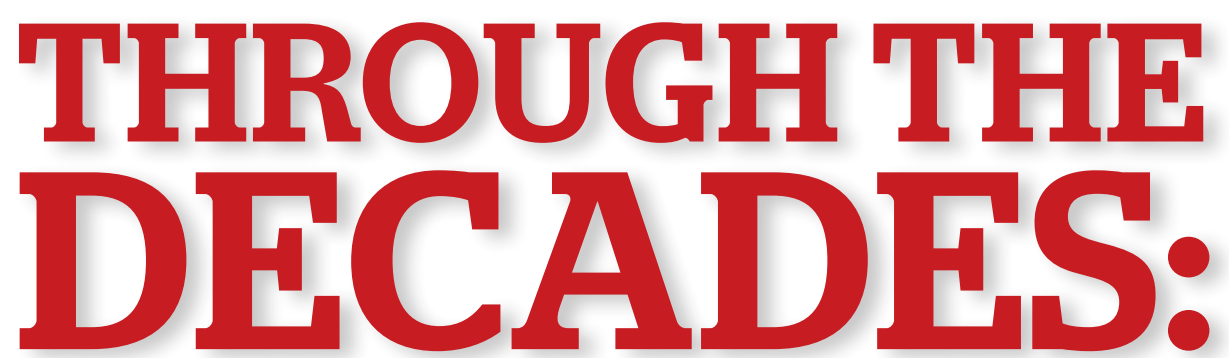

MOMENTS IN EMBRY-RIDDLE HISTORY

\section{oday, Embry-Riddle
Aeronautical
University is
synonymous}

with aviation and aerospace around the world. But it wasn't always that way. What began in 1926 with a businessman, a barnstormer and a WACO on a modest airstrip in southern Ohio would take decades of ups and downs before soaring to become the world's leader in aviation and aerospace education.

With a colorful cast of thousands, set against the turbulence of a corporate merger, a World War and a couple of natural disasters thrown in for good measure, the last 90 years at Embry-Riddle have been an adventure like no other. Like aviation itself, it would take clear and unwavering vision, a gift for reinvention and a tolerance for risk to make Embry-Riddle the great university it is today. Here are the key moments that show you how we made it happen.

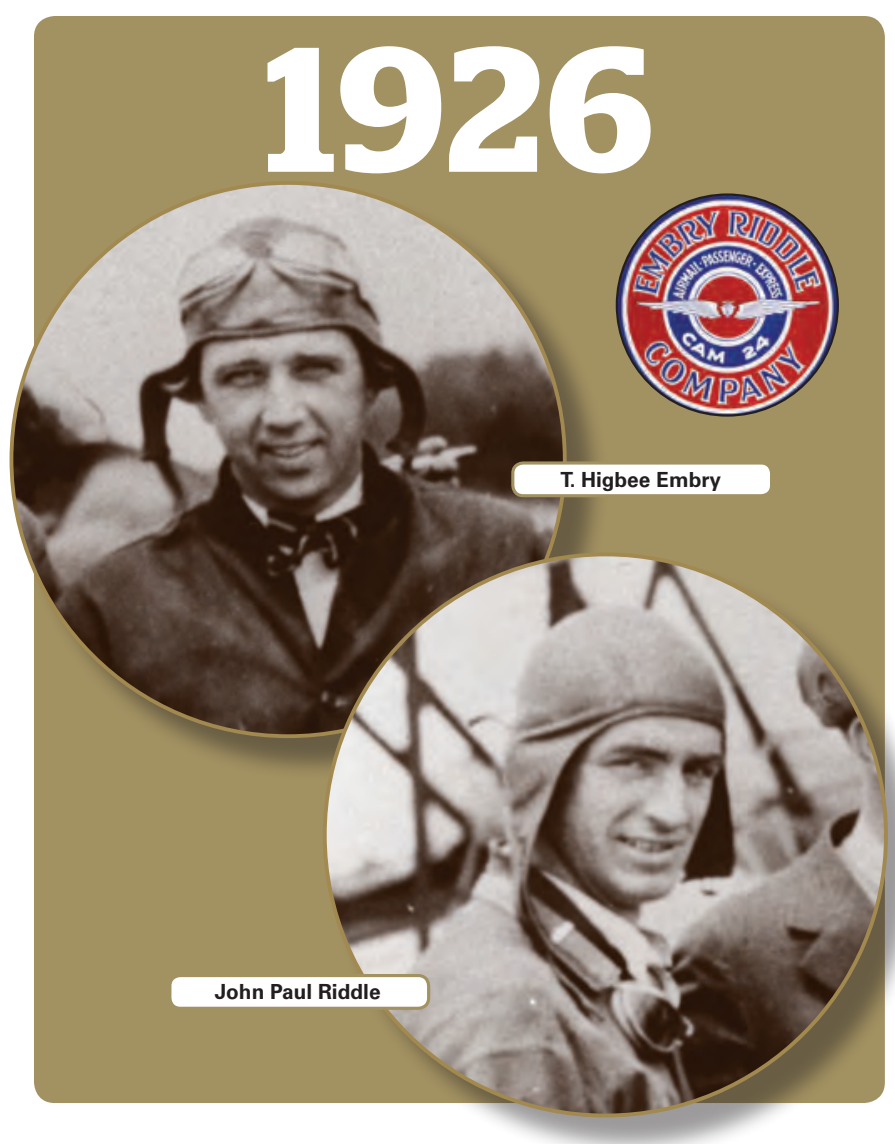

T. Higbee Embry and John Paul Riddle sign a contract on Dec. 17, 1925, to form a company in their names at Lunken Field in Cincinnati, Ohio, with Embry as president and Riddle as general manager. The company became known as "Cincinnati's first aviation corporation to amount to anything." The Embry-Riddle Flying School begins operating in spring 1926, gaining notoriety a year later after training student Frank Shelton to fly solo in only 5 hours and 34 minutes-believed to be the shortest amount of time at that point. The company slogan becomes "If it's flying we do it; if it's airplanes, we have them." |l||l|||||||||||||||||

- NOVEMBER •

Embry-Riddle secures the

U.S. Post Office

Air Mail contract

for service from

Cincinnati to

Chicago.
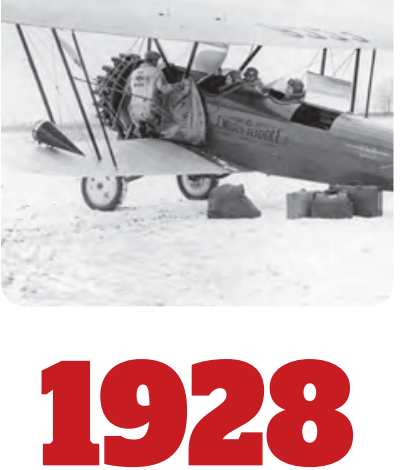

- JULY 29 •

Embry-Riddle holds its first graduation exercises.

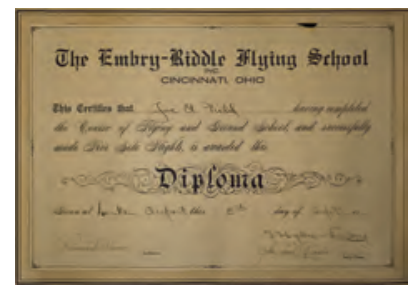

\section{'FOOTPRINTS'}

A reflection of Embry-Riddle's growth and change, as seen through its expanding facilities footprint

\section{6}

President Jack Hunt announces a 10 -year building program to accommodate 6,000 students at the Daytona Beach Campus.

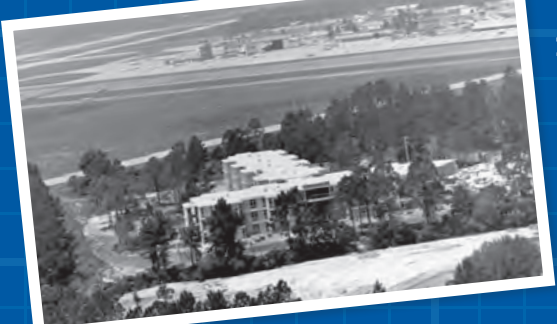

1968

Doolittle Hall, the

first brick and mortar

building to be built on

the Daytona Beach

Campus, is erected

(62,325 square feet). 
1929

Embry-Riddle's Flying School becomes one of the first

five schools in the country to receive an "Approved School Certificate" under the Air Commerce Act.

$\bullet$

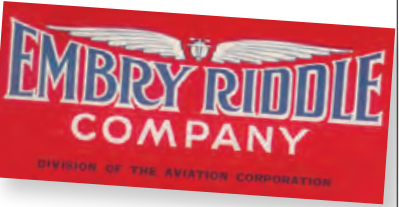

- APRIL •

Embry-Riddle Aviation Corporation is formed as part of an agreement of acquisition by the Aviation Corporation (AVCO). The next year AVCO forms American Airways and the Embry-Riddle division is ultimately absorbed by this new entity.

\section{0

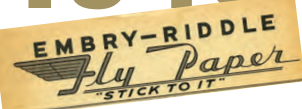

- OCT. 18 •

The first edition of the Embry-Riddle Fly Paper, a weekly newsletter published by the administration from 1940 to 1957 , is produced and distributed.

\section{- NOVEMBER •}

Embry-Riddle expands its technical school, renames it the Embry-Riddle School of Aviation and moves the

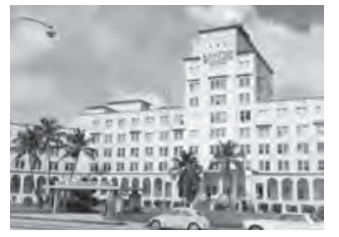

operation to the former Fritz Hotel. In 1942, the U.S. Army Service Command establishes a training detachment at the school.

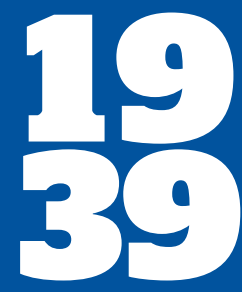

\section{- OCTOBER -}

John Paul Riddle partners with attorney John McKay and the Embry-Riddle Company is reborn as a seaplane base in Miami with two planes, one flight instructor and one maintenance man. Shortly

thereafter, Riddle enters into agreement with the University of Miami to train college students to fly under the 1939 Civilian Pilot Training Program; he leases a hangar at Municipal Airport and expands the training fleet to 15 aircraft.

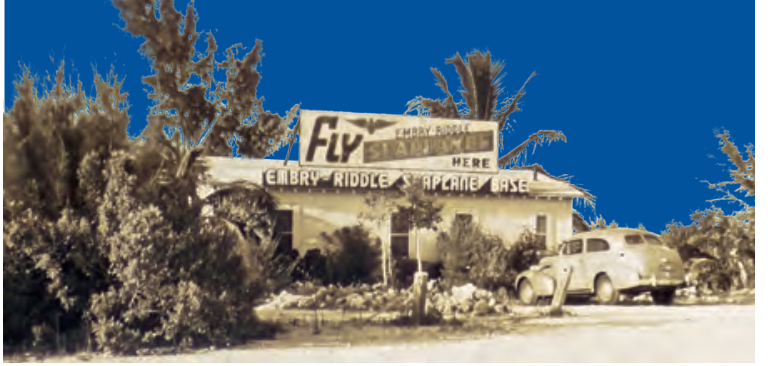

\section{- $1941 \bullet$}

March 22

Embry-Riddle opens the new Carlstrom Field, the first of five fields established for training pilots (1941-45) for the U.S. Army Air Corps/Army Air Forces and British Royal Air Force The latter were trained primarily at the No. 5 British Flying Training School,

which opened in Clewiston, Fla., in 1942, and operated under the 1941 Federal Lend-Lease Act.
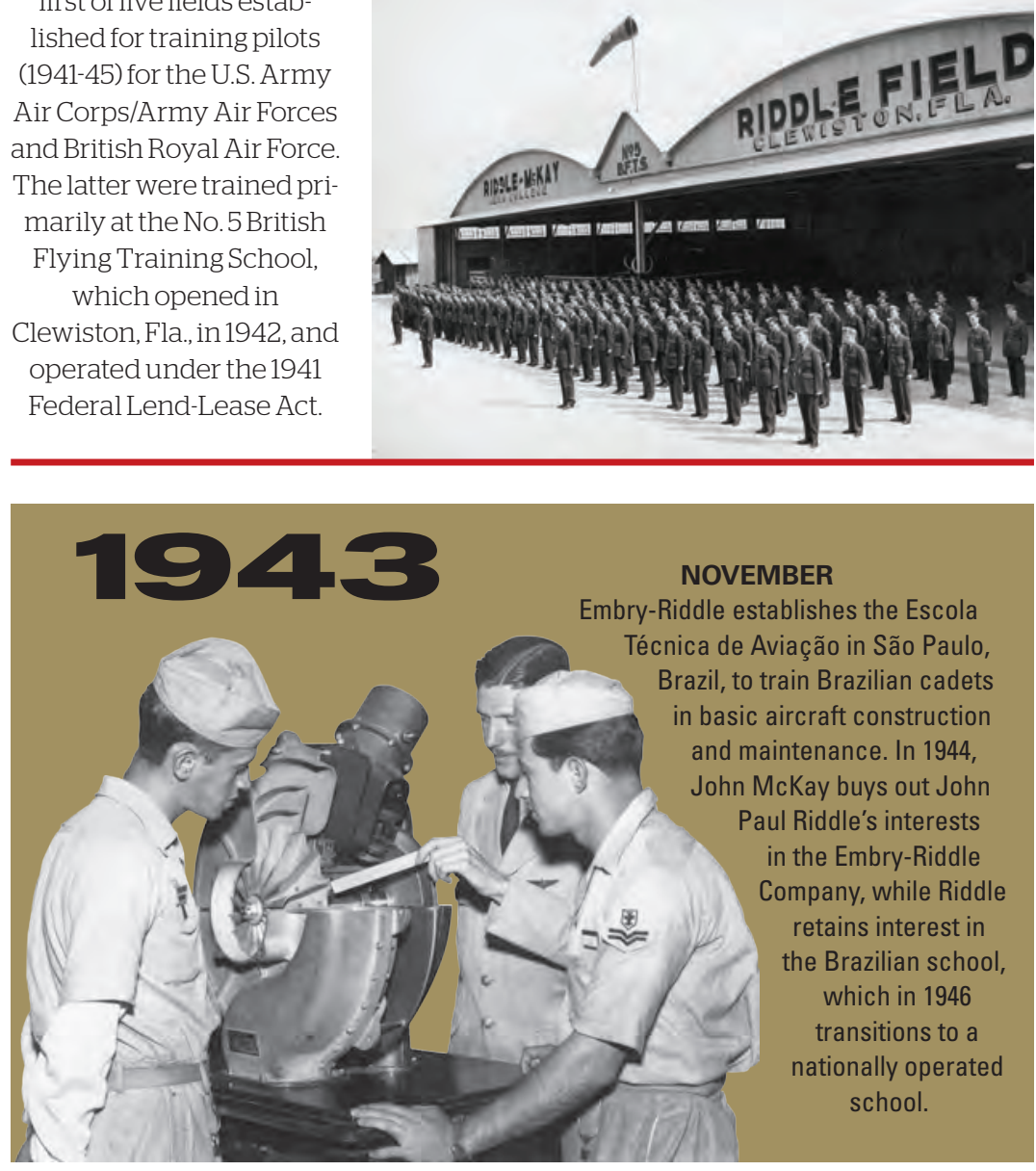
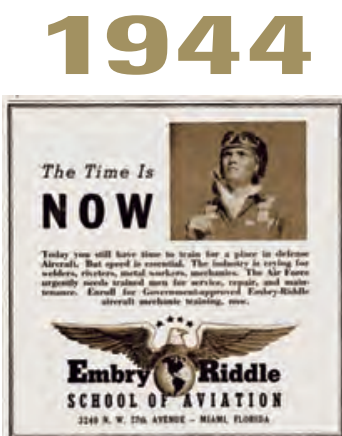

- OCTOBER •

Embry-Riddle becomes one of the first aviation schools to train veterans under the GI Bill ${ }^{\circledR}$.

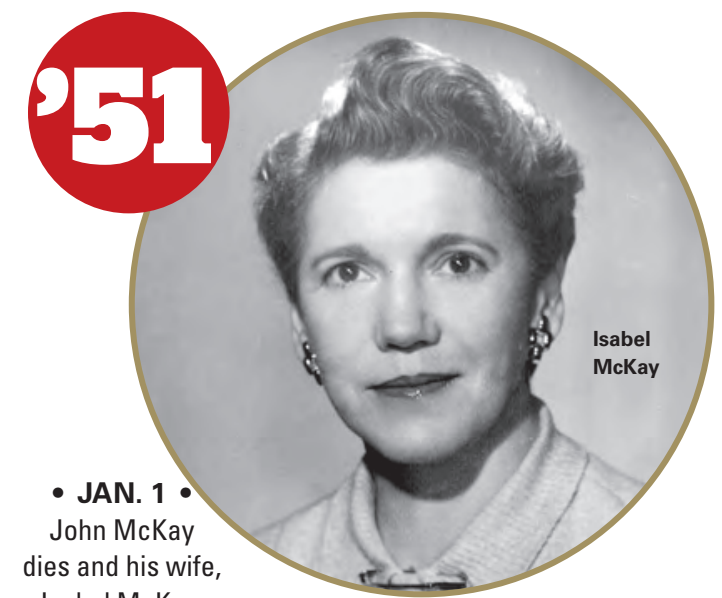

Isabel McKay,

becomes president

of Embry-Riddle.

\section{8}

Aug. 9 , the cornerstone for the new $\$ 1.4$ million Lindbergh Academic Complex (later called Alphabet Soup) is laid at the Daytona Beach Campus. Construction of buildings A, B, C, E, W, the annexes and offices is completed by 1980 (59,613 square feet). Demolished in 2012 to make way for construction of the new College of Arts \& Sciences building.

\section{0}

July 6 , the first Residence Center, the precursor to today's Worldwide Campus, is established at the U.S Army Aviation Center in Fort Rucker, Ala.

\section{1}

The Gill Robb Wilson Flight Center is constructed at the Daytona Beach Campus $(29,687$ square feet). Demolished in 2009 and replaced by the new Hagedorn Aviation Complex.

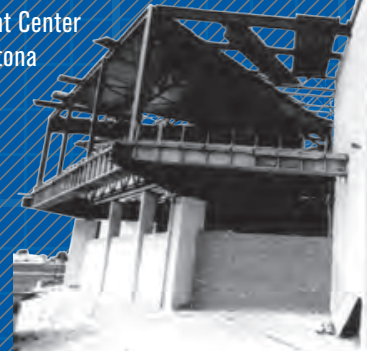

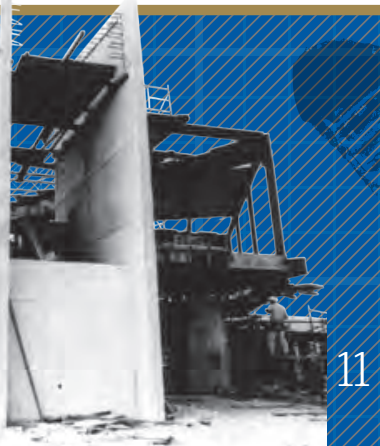




\section{Operation Bootstrap}

\section{IN 1963, NEWLY HIRED PRESIDENT}

Jack Hunt knew that in order to thrive, Embry-Riddle needed a cohesive campus with direct access to a runway. With its facilities scattered from Opa-locka and Tamiami Airport to 27th Avenue in downtown Miami, Hunt started searching for a new home for Embry-Riddle. When Dade County announced it planned to close Tamiami Airport, the move became inevitable.

\section{BACKSTORY}

Philip "Phil” Elliott Jr. (HonDoc 'O4; '72, DB, Non-degree), Embry-Riddle Trustee Emeritus; former member of the Committee of 100, a group of Daytona Beach businessmen and city leaders organized to bring industry and jobs to the area; and former Embry-Riddle attorney:

"In 1964, Jack Hunt came to Daytona Beach looking for a place to relocate ERAI. I wasn't on board at first. I saw the function of the committee as bringing in commercial businesses, not schools, and I was skeptical at first of Embry-Riddle's ability to make it financially. After meeting with Jack, I came around. Jack wanted to temporarily locate in old Naval Air Station buildings at the Daytona Beach Airport and to build the new campus at the Ormond Beach Airport. The attorney who represented both Ormond Beach and Daytona Beach had doubts about the prospects for the success of ERAI. Relying on his advice, the Ormond Beach City Commission required certain lease terms that Jack could not accept."

\section{John C. "Jay" Adams}

(HonDoc '08), Embry-Riddle Trustee Emeritus and former member of the Committee of 100:

"When Ormond Beach balked, Gary Cunningham, president of the
Committee of 100, suggested Jack call [Daytona Beach City Manager] Norm Hickey. Norm thought it was a great idea. Besides, they had all of these old World War II buildings at the airport that could be used."

The Daytona Beach City Commission voted favorably to lease 82.5 acres near the airport to EmbryRiddle, with an option to purchase.

Former Daytona Beach City Manager Norm Hickey:

"I thought Embry-Riddle had tremendous potential. I went down to the Miami Campus for a visit and there really wasn't much to see. But I liked Jack Hunt. I felt through Jack's leadership there was much more the university could accomplish and become, and that the impact of the university's future growth would grow the Daytona Beach community."

\section{THE MOVE}

Moving Embry-Riddle to Daytona Beach was a daunting task, especially because the school had limited finances. The Committee of 100 and the Jaycees, a local civic group, rallied the community to help and the effort became known as "Operation Bootstrap."

\section{Jay Adams}

"It meant 'by the skin of your teeth.' It was a term people used because they knew it was grass roots, for sure, and it was done by sweat equity and volunteer labor, and other people's gasoline and trucks. But we felt like we were getting something. We were starved for employers and payrolls."

The move began on April 25, 1965 and was completed three days later.

Jim Ladesic ('67, DB), who later became an Embry-Riddle professor and is now associate dean of industry relations and outreach for
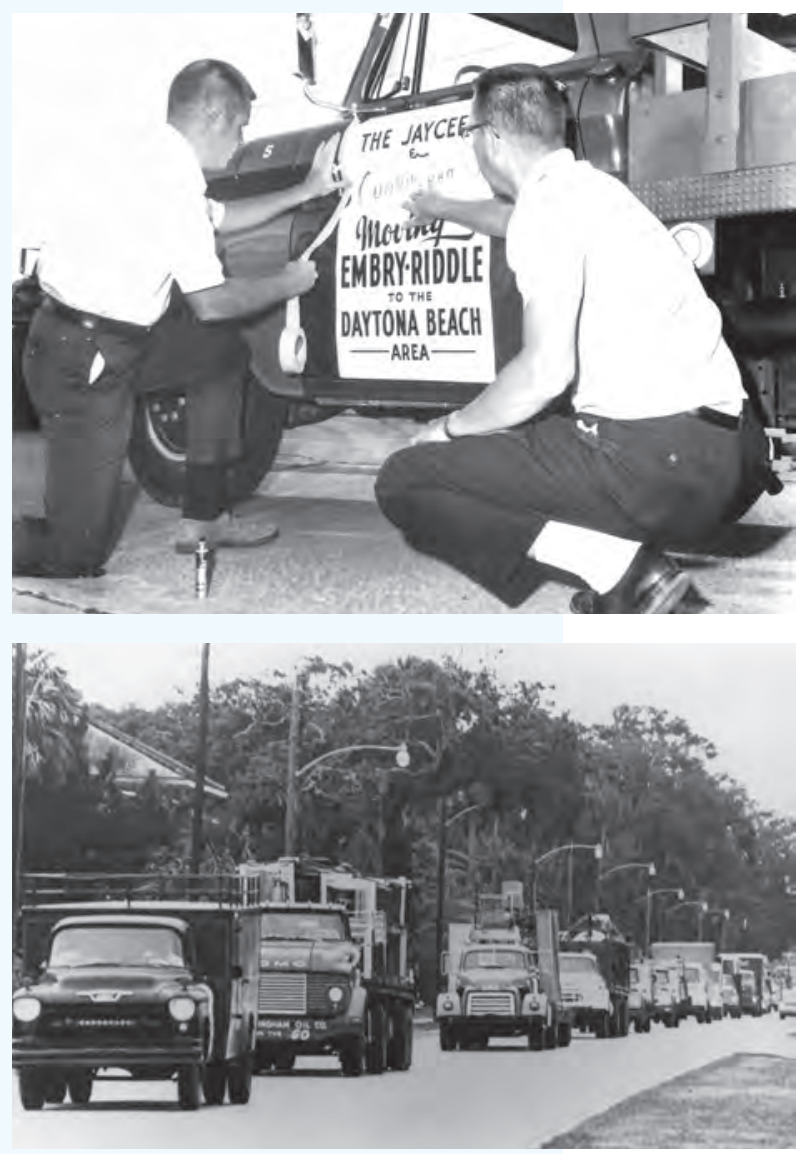

the College of Engineering, was a student at the time:

"At the beginning of the first trimester in 1965, a group of us were standing outside the Embry-Riddle bookstore in Miami, waiting for it to open. It was there that we saw a notice on the corkboard. It read: 'Notice: As of April, 1965, the University will be moving to Daytona Beach.' There was no explanation-just 'We're moving!'

"Many of the students chose not to stay. We had something like 400 students enrolled in Miami, but only 283 made it to Daytona-I was one who made it."

-Sara Withrow

\section{6}

The International Campus moves its offices, pictured left, from Bunnell, Fla., to Beville Road at Williamson Boulevard in Daytona Beach, the current location of Embry-Riddle Aeronautical University's Worldwide Campus headquarters.

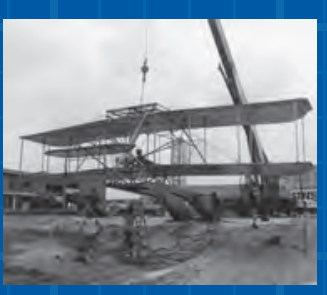

1989

October, the Wright Flyer sculpture is erected at the Daytona Beach Campus.
1990

NASA donates Lockheed F-104 to the Prescott Campus. Starfighter №. 811

(A)

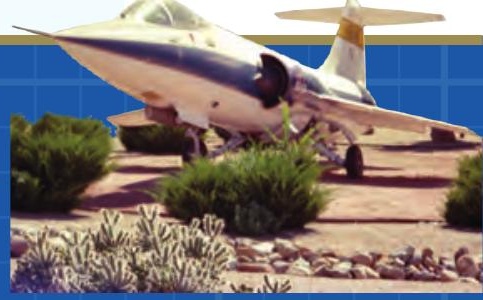




\section{A Vision for a Western Campus}

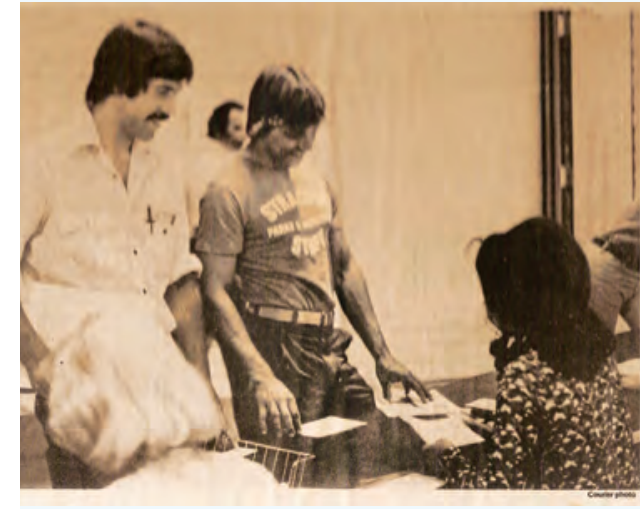

EMBRY-RIDDLE PRESIDENT JACK HUNT LIKED TO come into his office on Saturdays and open his own mail. One such Saturday, he noticed a flyer from the U.S. Steelworkers organization advertising a "bargain" deal on a 500-plus acre propertythe former home of Prescott College in Prescott, Ariz., which had gone bankrupt. A lienholder on the property, the organization was seeking an investor. Hunt immediately saw potential in the land and its collection of abandoned buildings as a prep school for students who struggled with academics; but that idea never took off. Instead, Hunt would find his answer in the overflow of flight students at the Daytona Beach Campus and the area's 300-plus sunny flying days per year, a perfect combination resulting in a ready pool of aeronautical science applicants for the new campus.

\section{THE PRESCOTT PLAN}

Trustee Emeritus John C. “Jay” Adams (HonDoc '08) remembers:

"We had so many flight students coming to Daytona, that we told them, 'You can register for aeronautical science, but you won't be able to fly until January; however, if you go to Prescott, you'll be able to fly immediately.' That's how it really started and then we added engineering out there, and one thing and another.

\section{THE PIONEERS}

John Jenkins, now a tenured professor, was teaching mathematics part time at Embry-Riddle's Daytona Beach Campus when he was hired as the first faculty member for the Prescott Campus. Arriving in the summer of 1978, he recalls opening the campus for its first class of 240 students, five of whom were women:

"It looked like a ghost town. We had all of eight faculty."

Sarah Thomas, director of library services and a 35-year employee at the Prescott Campus, arrived in 1980.

"There were the little slump stone brick buildings that were
O

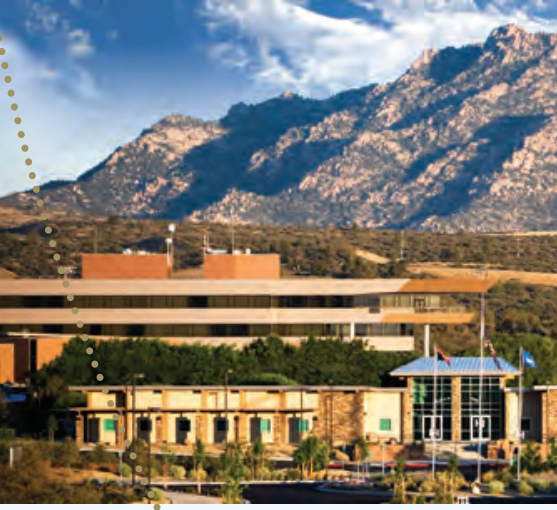

$\therefore$

inherited from the old Prescott College and everrything was brown; there was no grass. But we had such a pride and a love for this little out-of-the-way place. It was a new erfdeavor, a new enterprise, and people wanted to be a part of it.".

\section{FIRST STUDENTS}

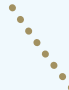

Steve Kirsch ('80, PC), now a pilot at United Air Lines, was’ǫne of the first students to enroll at the new campus. He had spent ơne year at the Daytona Beach Campus and remembered how diffẹrent Prescott was:

"You are in the desert; it's dirty and dry. Then during orientation, the nurse says, 'This is what you do if you get bit by a rattlesnake, a tarantula, a scorpion."

But he quickly fell in love with the area's natural beauty and low-key lifestyle. He and friend Mike Honey ('82, PC) started a rugby team that competed against other university members of the Arizona Rugby Union; and Kirsch ended up working at most of Prescott's local restaurants and bars to support himself through school.

"There was no liquor license, so you couldn't drink a beer on campus. So we had keggers. We would get a keg, go off somewhere and make a bonfire. And the most amazing thing was you'd look up and see every star you could imagine."

Peg Billson ('84, PC), president and CEO of BBA Aviation Aftermarket Services, remembers how the decision was made for her to attend the Prescott Campus:

"I'm graduating from high school in Maryland and it's time for me to go to Embry-Riddle, and naturally Daytona Beach is a lot closer to Maryland than Prescott, Arizona.

"I argued with my parents about going to Florida over Arizona for months. Then my dad came back from a business trip in Daytona Beach over spring break (in the 1970s!). He walked through the door, pointed at me and said, 'You are going to Arizona!' Prescott just fit me like a glove."

-Melanie Stawicki Azam

\section{5}

The ICI Center/Field House is constructed at the Daytona Beach Campus (67,559 square feet).

\section{5}

The Capt. Willie Miller Instructional Center, pictured left, opens at the Daytona Beach Campus $(20,415$ square feet).

\section{5}

The Lehman Engineering and Technology Center is built at the Daytona Beach Campus $(127,706$ square feet).

\section{5}

Robertson Aviation

Safety Center is

constructed at the Prescott Campus (7,255 square feet)

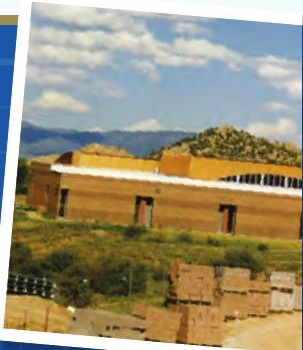




\section{* 1970 *}

\section{EMERY-RIDDLE} ERONAUTICAL UNIVERSITY

- JUNE 9 •

Embry-Riddle Aeronautical Institute becomes Embry-Riddle Aeronautical University. It touts a two-college structure: Aeronautical Studies and Aviation Technology.
- 1975 - 1979 .

Embry-Riddle's College of Continuing Education opens 15 European Residence Centers and 20 U.S. Residence Centers - 1977 .

The Daytona Beach Campus forms the office of Graduate Studies to assist in the management of graduate degrees offered through the university's College of Continuing Education and partner universities/consortia.

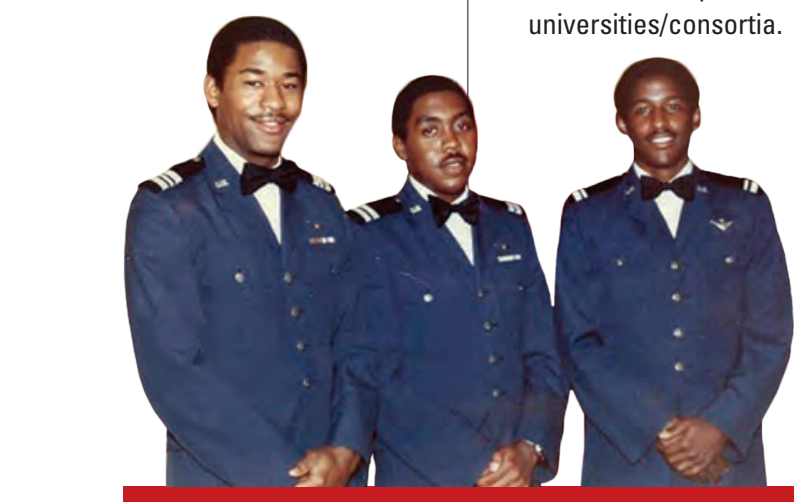

•••。…

Air Force ROTC Detachment 157 debuts as the first ROTC program at Embry-Riddle.

Above: Three of the first African-Americans to graduate from Det. 157, circa 1982

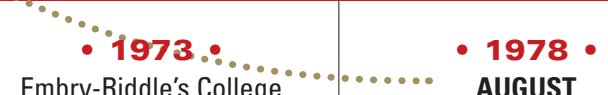

Embry-Riddle's College AUGUST

of Continuing Education begins offering the university's first graduatelevel program, an M.S. in Aviation Management, through a partnership with the Miami Education Consortium and Biscayne College.

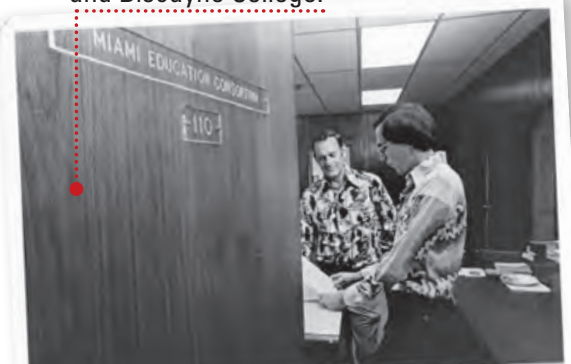

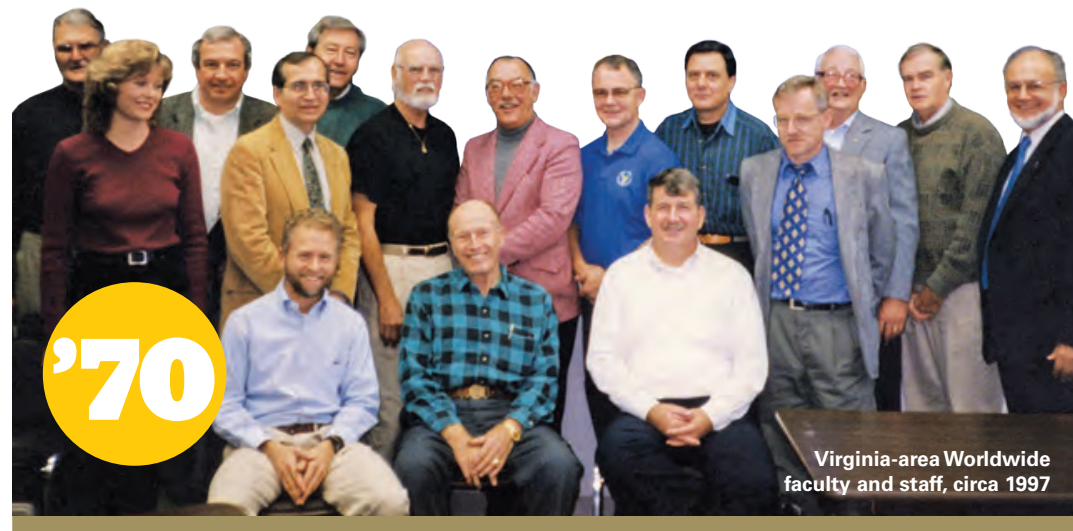

\section{REMOTE LEARNING PLANTS SEEDS FOR EMBRY-RIDDLE WORLDWIDE

$$
\text { - July } 6 \text { • }
$$

The first Residence Center is established at the U.S. Army Aviation Center in Fort Rucker, Ala., to assist military students in attaining credits for the purpose of future matriculation to the university's home campus. Two similar centers open later that year: Fort Stewart/Hunter Army Airfield in Alabama, and Fort Wolters, Texas; and in 1971, a fourth center opens at Fort Eustis, Va. In 1973, the Residence Center operation is renamed the College of Continuing Education and its students are no longer required to

matriculate to the main campus to complete their degrees.

Jack Thompson, director of the Embry-Riddle Worldwide Campus at Fort Eustis, Va., started as an adjunct faculty member at the Fort Eustis Residence Center in 1974. Recalling those early days, he says: "From 1974 to 2001, the classes were held in World War II 'temporary' buildings. Each building had two classrooms on the first floor and one classroom upstairs. Both floors had 8-inch square posts throughout the rooms and some of the students had to peer around the posts while I conducted class. They weren't made for classrooms, but for bunks and soldiers. [Furthermore] at

times you had to stop teaching if your class was on the

first floor, because you were being drowned out by the boots on the stairway to the second floor."
Time magazine article calls Embry-Riddle the

"Harvard of the Sky."

Campus opens in Arizona with 240 students.

\section{9}
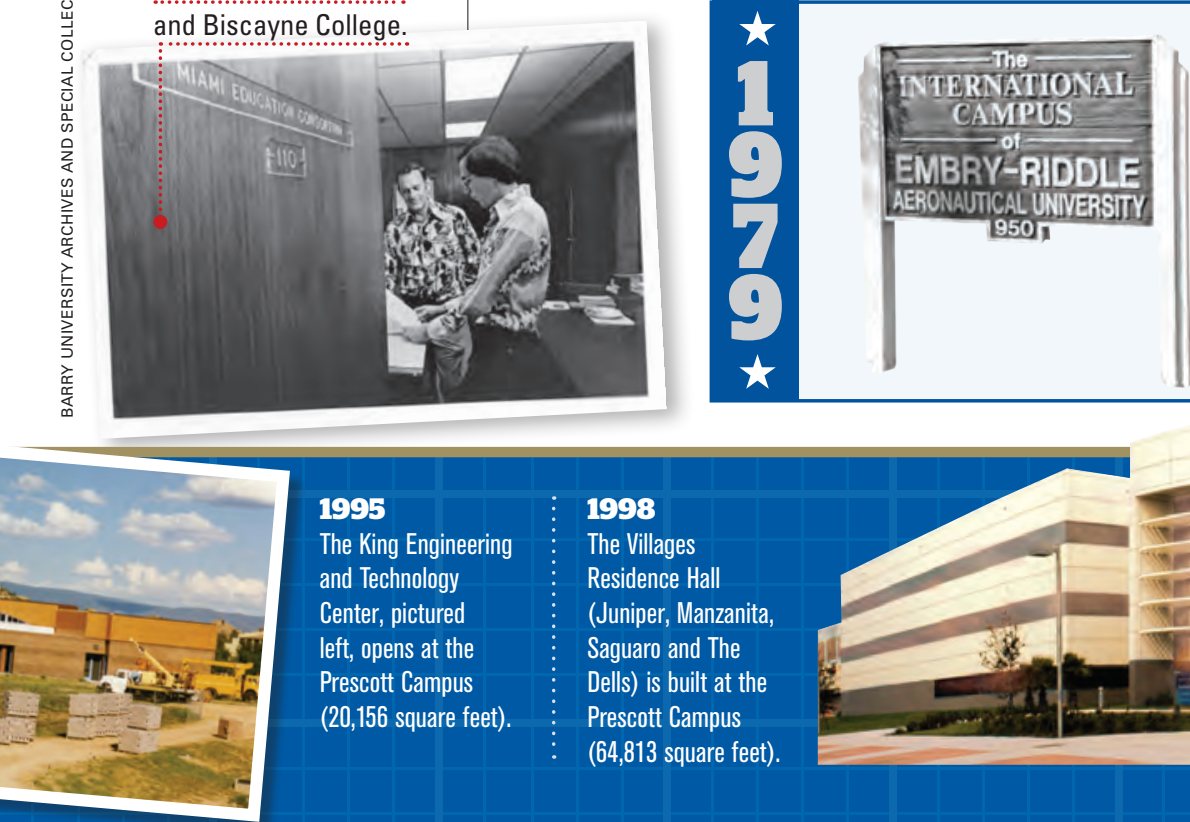

President Jack Hunt implements what he calls a "new single university - multiple campus concept" that divides the university into three campuses: the Daytona Beach Campus, the Prescott Campus and the International Campus (later becoming the Worldwide Campus), which includes professional programs, the College of Graduate Studies, the College of Continuing Studies and the External Degree (Independent Studies) Program.

\section{5}

The King Engineering and Technology Center, pictured left, opens at the Prescott Campus (20,156 square feet).

\section{8}

The Villages Residence Hall (Juniper, Manzanita, Saguaro and The Dells) is built at the Prescott Campus (64,813 square feet).

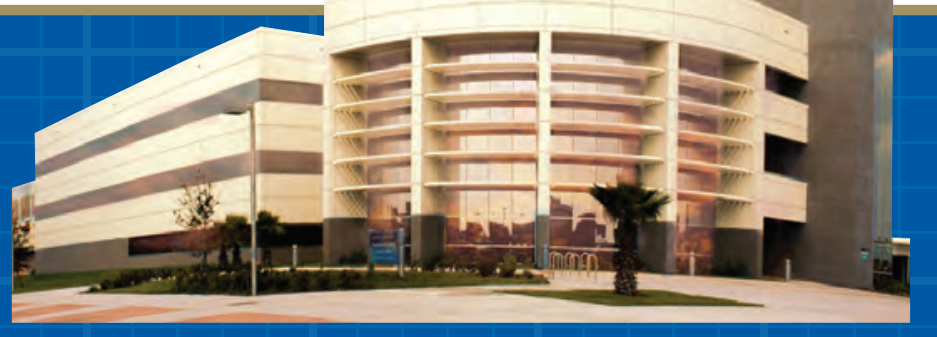

2002

The College of Aviation building, pictured left, is built at the Daytona Beach Campus (75,313 square feet). 


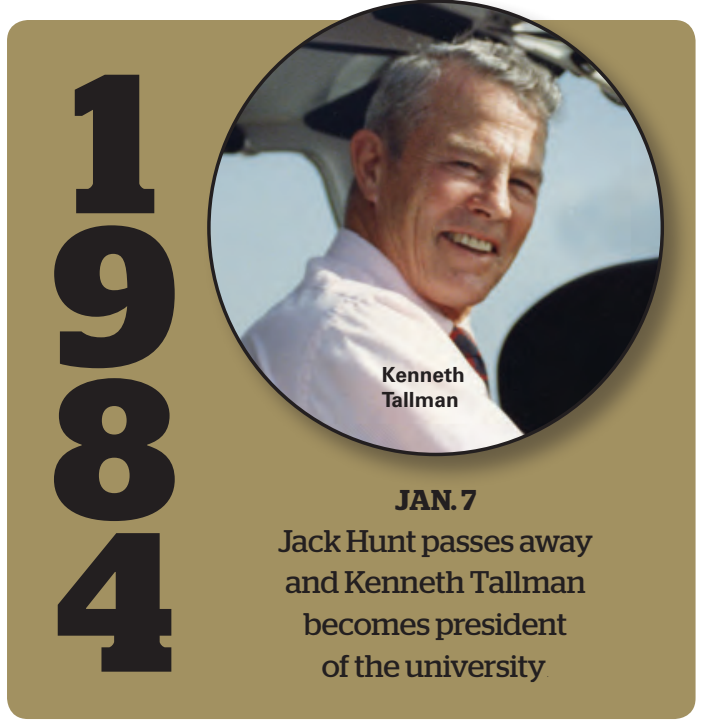

- $1982 \bullet$

International Campus enrollment surpasses both the Daytona Beach and the Prescott campuses with

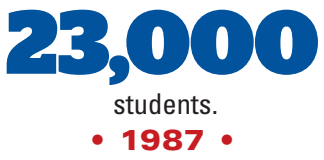

The Daytona Beach Campus offers its first graduate programs: M.S. in Aeronautical Engineering, MBA Aviation, M.S. in Aviation Management and Master of Aeronautical Science. Prescott Campus launches the M.S. in Business Administration, M.S. in Aviation Management and the Master of Aeronautical Science.

$$
\text { - }
$$

Embry-Riddle's Daytona Beach Campus is reinstated as a member of the National Association of Intercollegiate Athletics, following a 10-year hiatus of inactivity, and begins competing in men's basketball, baseball, soccer, tennis and golf. Women's sports begin in 1995 with volleyball.

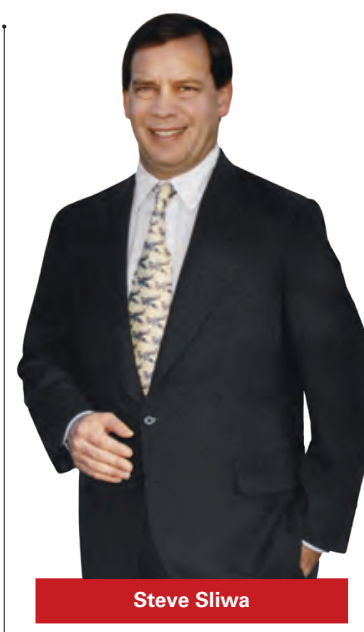

- 1991 •

Steve Sliwa becomes president of Embry-Riddle Aeronautical University.

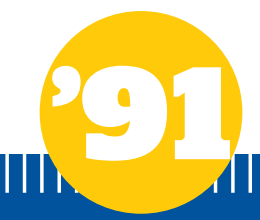

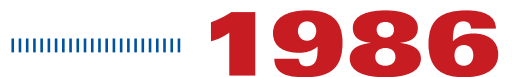

APRIL

Popular entertainer and comedian Bob Hope delivers the keynote address at the spring commencement ceremony at the Daytona Beach Campus.

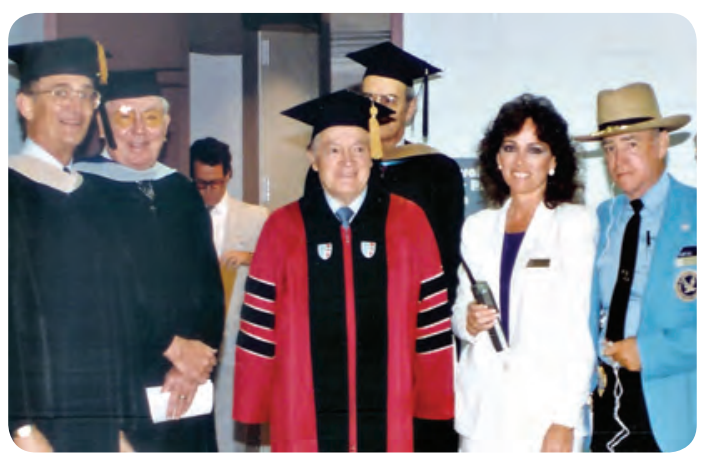

- 1992 •

The Daytona Beach Eagles Flight Team wins its first National Intercollegiate Flying Association's (NIFA) Safety and Flight Evaluation National championship. In 1993, the Prescott Golden Eagles Flight Team wins its first NIFA Safety and Flight Evaluation National Championship. To date the Golden Eagles team has tallied nine national championships.

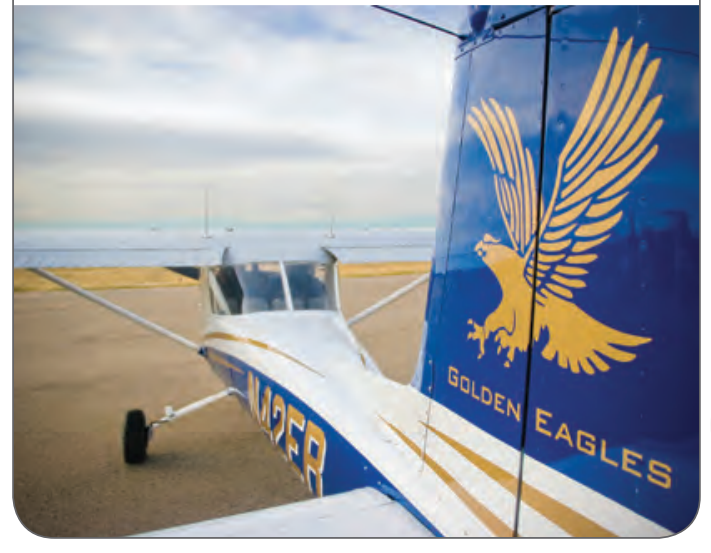

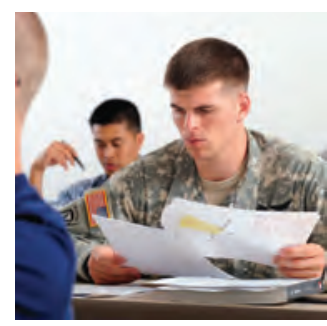

- 1995 •

The College of Continuing Education/International

Campus changes its name to Extended Campus, which comprises more

than 100 residence

centers and teaching sites in 32 U.S. states and five

European countries.

$$
\text { - } 1997 \text { • }
$$

Susan L. Still-Kilrain (' 82, DB) becomes the first Embry-Riddle alumna/

NASA astronaut to go to space

\section{(STS-83 Columbia).}

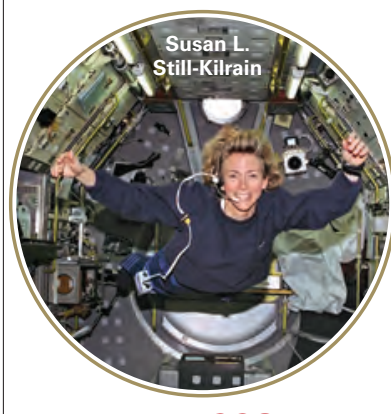

- 1998 •

George H. Ebbs becomes president of Embry-Riddle.

The wrestling club, which formed in 1988 at the Prescott Campus, becomes that campus' first intercollegiate sport, competing as a member of the National Association of Intercollegiate Athletics (NAIA). In 1997, women's sports begin at the Prescott Campus with volleyball. In 1998, Chance Farrar ('OO, PC) becomes the Prescott Campus' first NAIA Individual National Champion in Wrestling. Seven more NAIA individual wrestling championships would follow. The most recent was awarded in 2015 to student Jose Cruz III.

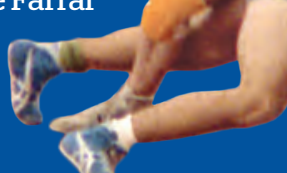

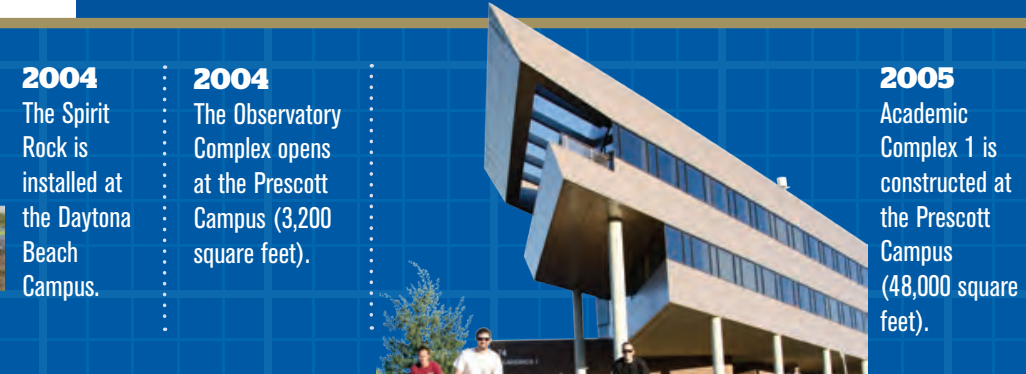

2006

Prescott Campus' Visitor Center/ Administration building opens $(13,028$ square feet). 


\section{The Jack Hunt Era}

\section{IN 1963 JACK HUNT TOOK THE REINS OF}

Embry-Riddle Aeronautical Institute and turned it on its ear. Over the next 21 years he transformed it from a 500-student flight/technical school in Miami to a multi-campus, fully accredited university with nearly 35,000 students and a worldwide presence. The Jack Hunt Era is the stuff of legend, but memories of the man, his passion and legacy still live on in the hearts and minds of those who were fortunate to have known him.

\section{THE MAN}

John C. “Jay” Adams (HonDoc '08), Embry-Riddle Trustee Emeritus and friend to Jack Hunt:

"Jack was charismatic, capable and very dedicated. He was more of a risk taker than a lot of people were com fortable with, but he looked back at the history of what Embry-Riddle had been and he just knew he could turn it around and make it into something. As a member of the early board, oftentimes we would worry about what Jack would do next. 'Throttles full ahead, damn the torpedoes,' that's just how Jack was."

Philip “Phil” Elliott Jr. (HonDoc 'O4; '72, DB, Nondegree), Embry-Riddle Trustee Emeritus, former neighbor and friend to Jack:

"He was a very wise and a very complex person. He was much more sophisticated than his personality and his easy way of making friends would suggest."

Growing up in California, Jack worked as a firefighter before joining the U.S. Navy in 1942. In 1957, he commanded the ZPG-2 airship Snowbird on a nonstop flight that set world records for distance and endurance (see Timeline: 1957) Jack earned a master's degree from Barry College (now university) in 1964, while he was working for Embry-Riddle. He used his thesis, An Investigation of Accreditation Procedures Relative to the Special Institution, as support for Embry-Riddle's accreditation by the Southern Association of Colleges and Schools Commission on Colleges.

Lynne Hunt Doten, Jack's surviving spouse:

"Jack was a forward-thinking visionary and a born leader. For instance, in order to conduct the all-weather evaluation mission with the Snowbird, he had to get permission from eight admirals. He had to sell his idea to the Navy. Those around him thought he might get one or two to agree and it would take a year with all the red tape. He got eight signatures in a day-an accomplishment that rivals the flight itself."

Jack was driven to make a difference for others in his career and in his personal life. In 1981, he married Lynne and immediately began the process to legally adopt her five children.

Jack's son, Geoff Hunt ('86, DB), a site executive and multi-vendor supply chain director for GE Healthcare, remembers:

"'Have a plan; be dependable' were his calling cards It is unlikely that I would have learned how to manage complex projects, take calculated risks, or even attend college, if not for his influence. When I was adopted at 18 , my whole world changed."

\section{HIS PASSION AND LEGACY}

\section{Jay Adams:}

"Aviation and education were both passions of Jack's. He lived, breathed and worked on Embry-Riddle, except when he was sleeping, and then he was probably dreaming about it."

\section{Lynne Hunt Doten:}

"When Jack got involved with Embry-Riddle he could see its potential. His passion to fulfill that potential propelled him forward. He was like a magician inventing, running and financing something unique and never done before."

Jack's daughter, Sarah (Hunt) Collins ('89, DB), an elementary school Title I Teacher on Assignment:

"He valued education and thought of him-

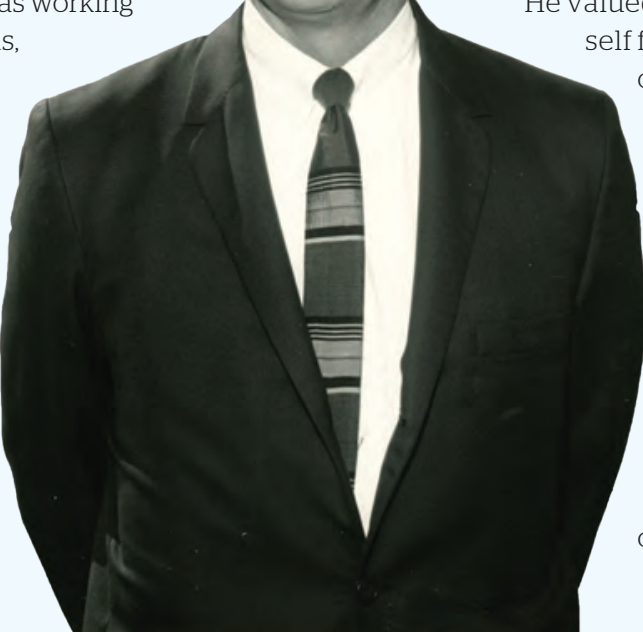
self foremost as a teacher. He wanted others to have opportunities for learning. He was father to the modern-day Embry-Riddle and he took that parental responsibility seriously."

Fueled by his passion, Jack worked to the end to ensure Embry-Riddle's success. He died in office in 1984 at the age of 65.

\section{Phil Elliott:}

"The significance of Jack Hunt for this university cannot be overstated."

\section{-Sara Withrow}

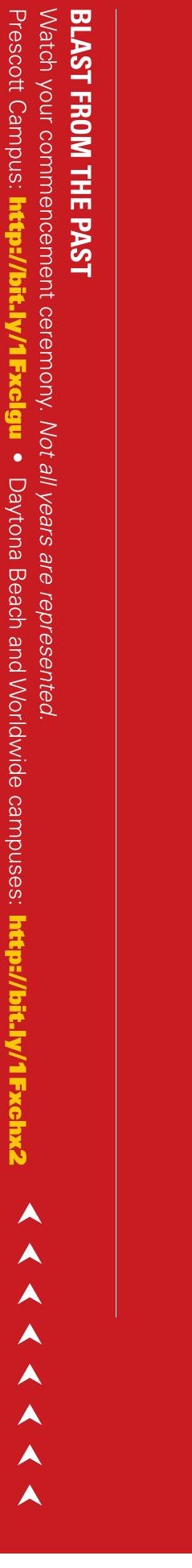

\section{6}

The Aerospace Experimentation and Fabrication building is built at the Prescott Campus (22,486 square feet).

\section{6}

Dec. 25, a tornado strikes the Daytona Beach Campus, leveling the aircraft maintenance hangar, damaging Spruance Hall, the main administration building, beyond repair, and inflicting minor damage on three other campus structures. Additionally, 40 training aircraft-two-thirds of the fleet-are destroyed. The total damage is $\$ 50$ million. The administration, faculty and staff rally, however, and the spring 2007 semester is delayed by only six days.

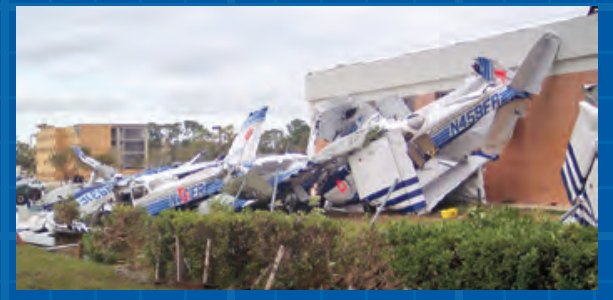


- 2000 •

Embry-Riddle's men's basketball team at Daytona Beach wins the university's first NAIA Division II National Championship. In 2013, men's tennis at the Daytona Beach Campus follows suit, winning the university's second NAIA Division II National Championship.

U.S. News \& World Report ranks Embry-Riddle's Aerospace Engineering program No. 1 among the nation's undergraduate aerospace engineering programs without a Ph.D. The program has been ranked No. 1 each year since, through 2014.

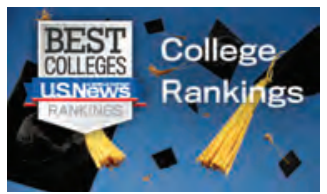

- 2006 •

John P. Johnson becomes president and CEO of the university.
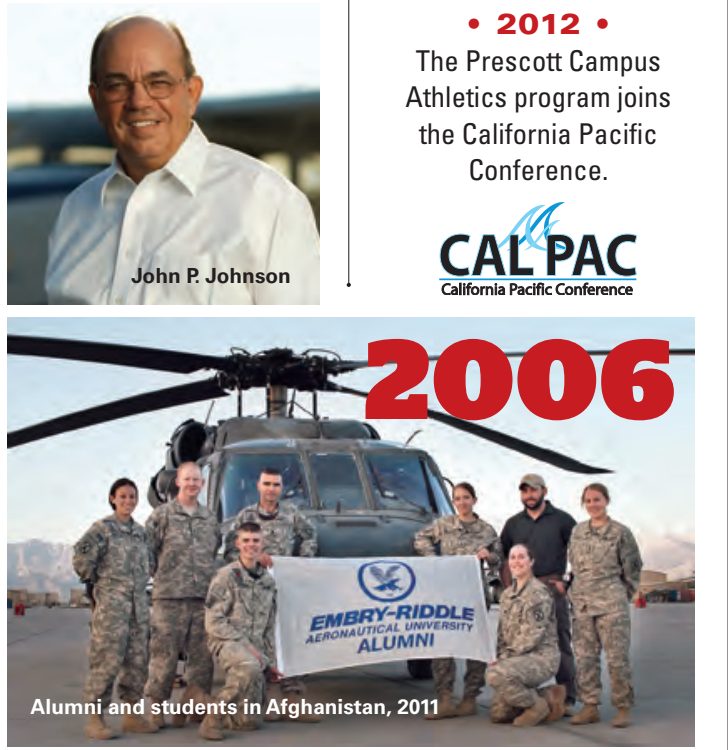

Worldwide Campus, a dedicated division for student advising and course quality, is created and includes online offerings. It absorbs the formerly named Extended Campus.

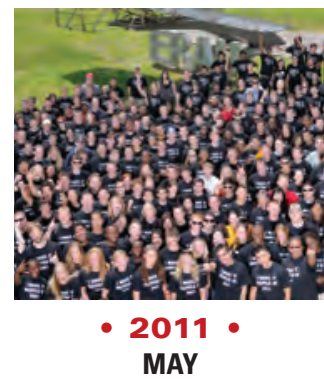

Embry-Riddle

surpasses

\section{0,000} alumni.

- 2012 Athletics program joins the California Pacific Conference.

\section{CALPAC}

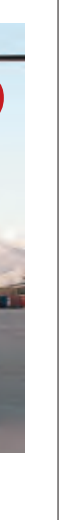

The Prescott Campus

Embry-Riddle launches its first Ph.D. programs: The Ph.D. in Engineering Physics and the Ph.D. in Aviation, which is the first of its kind in the nation. In 2013, Embry-Riddle confers its first Ph.D. degrees to eight students, five in aviation and three in engineering physics.

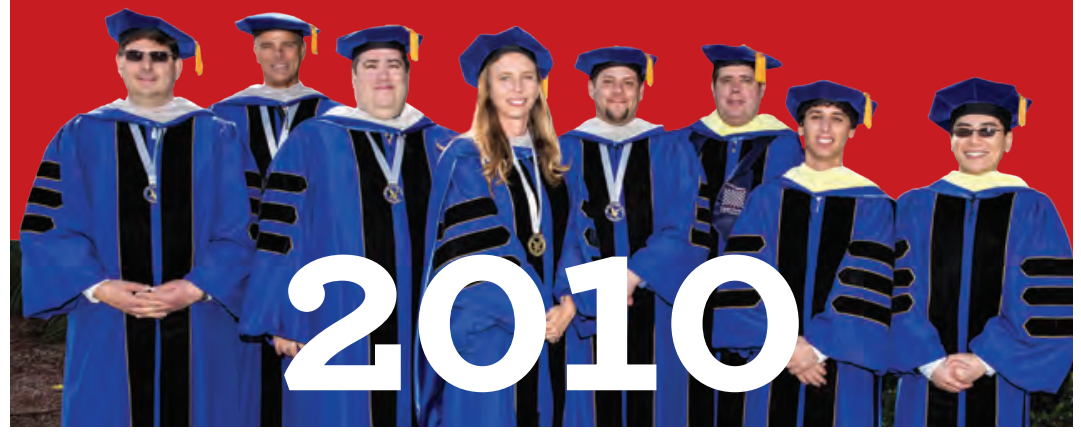




\section{, National Championship Relived}

\section{A FLEDGLING ATHLETICS PROGRAM WITH}

five sports, no facilities of its own, only two years of membership in the National Association of Intercollegiate Athletics and a terrible losing streak is what Coach Steve Ridder signed onto when he came to Embry-Riddle in 1989. Eleven years later (2000), he led the Eagles' men's basketball team to its first national basketball championship, defeating the College of the Ozarks in Branson, Mo. Since then, the Eagles have come close to doing it again, with 14 subsequent visits to the national tournament-but that legendary victory still stands as an extraordinary achievement for Embry-Riddle Athletics.

\section{THE GAME}

\section{Coach Steve Ridder:}

"We came out of the gates quickly. Our No.1 goal was to control the tempo. We had to take the crowd out of the game because we only had about a hundred fans there. We scored the first shot and never fell behind."

The Eagles were up 37-26 at the half, but the Ozarks' Bobcats didn't go down without a fight. With less than 5 minutes left in the game, the Eagles led by only 3 points.

Jason Cruse ('OO, DB), who made the first 3-pointer for the Eagles that day, had broken his left forearm earlier in the season but ended up coming back and earning the tournament MVP:

"The Ozarks started making this run in the second half. They played great defense and our shot clock was running down. Yon Price was 3 or 4 feet at the [shot clock] buzzer. It killed their momentum."

Yon Price ('OO, DB), team captain that season, and one of Cruse's roommates:

"I remember looking at the shot clock and seeing there were needed enough space to get a shot off. I tried to get open; I go up, behind the 3-point line. He banked the 3-point shot 3 seconds left. I just and I just got it off. At the time, I didn't think it was a big deal. After the game, I realized 'the shot' just took the momentum out of the Ozarks and their crowd. Fortunately, I had been in championship games before, so I was focused late in the game."

\section{THE MYSTERY MASCOT}

At the final buzzer, the score was 75-63, Embry-Riddle. The celebration ensued, but one thing gave Coach Ridder pause..

John Phillips ('90, '92, DB), director of sports marketing (now director of athletics at the Daytona Beach Campus), recounts:

“Coach Ridder's brother, Dan, drove all night from Kentucky to get to the final game. We didn't have our mascot there, so he decided he wanted to be it. He went to the costume stores, but the closest he could get to an eagle was combining a Daffy Duck face with a chicken head.

"So this chicken is on the court, he's in the huddle, he's all around, and Coach Ridder is wondering why this chicken is part of our team now. It's like this the whole game.

"Then the game ends. We win the national cham pionship; it's the greatest moment of his coaching career ... and this chicken is hanging out with everyone. And, Coach is saying, 'Who is this? I want to celebrate with my team!'

"So he takes the mascot's head off and sees that his brother was there the entire time."

- Alan Marcos Pinto Cesar

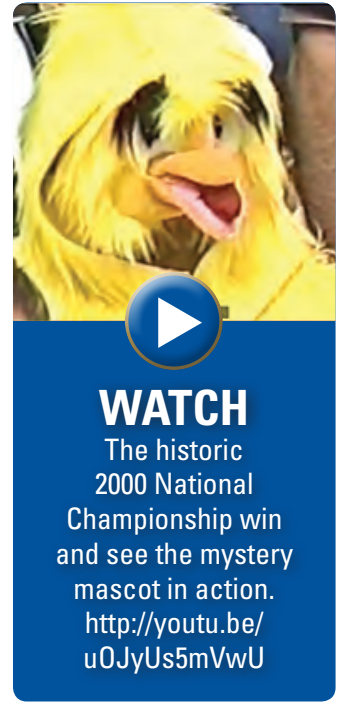

Compiled by Sara Withrow in cooperation with University Archivist Kevin Montgomery 


\section{SPECIAL TO THIS ISSUE}

\section{BY ANTHONY BROWN}

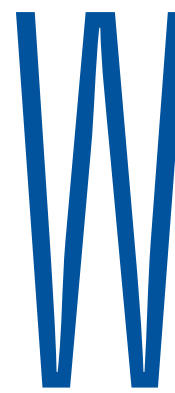

hen John P. Johnson took the helm as the fifth president and CEO of Embry-Riddle Aeronautical University 10 years ago, it marked the beginning of a vision for the university that would place it on a course for growth for many years to come.

Under his guidance, Embry-Riddle has made historic progress developing a solid foundation of growth in student enrollment and degree programs (from 35 to 80), recruiting internationally recognized faculty, expanding facilities and establishing first-of-their-kind colleges and academic programs. On Johnson's watch, Embry-Riddle has risen in academic reputation, national rankings, research and scholarly activity, and global outreach.

In light of his retirement in May, we sat down with Johnson to talk about one of the most memorable and innovative eras in Embry-Riddle's history.

\section{If you could sum up your administration in one word, what would it be? Why?}

Transformative. Working with the outstanding faculty, staff and students, we have taken the university to another level. Embry-Riddle is truly on a positive course as an entrepreneurial university.

When I came to Embry-Riddle in 2003, it was already an excellent institution with a focus on teaching and excellence in the classroom, preparing individuals to enter the aerospace industry. We have not lost those noble attributes, but have expanded on them in an exponential way. Embry-Riddle has moved from a Level IV, SACS-accredited institution to a Level VI, multi-doctoral granting, research-intensive university. We began to hire world-class faculty who had an inherent expectation to conduct research, discover new knowledge, publish and receive grants that would allow them to develop and create unique and innovative startup companies.

These research opportunities have a positive, direct effect on student success. A large percentage of our students are engaged in research projects with our talented faculty. This early opportunity, along with internship placements with major aerospace companies, is responsible for 96 percent of our students obtaining employment within one year of graduation.

\section{Obviously, there have been many significant physical changes to all of the campuses in the past 10 years. But how has the culture of Embry-Riddle changed? \\ From the outset it was important to strike a balance} on the "three legs of the stool" that make up the mission of any great academy: teaching, research and

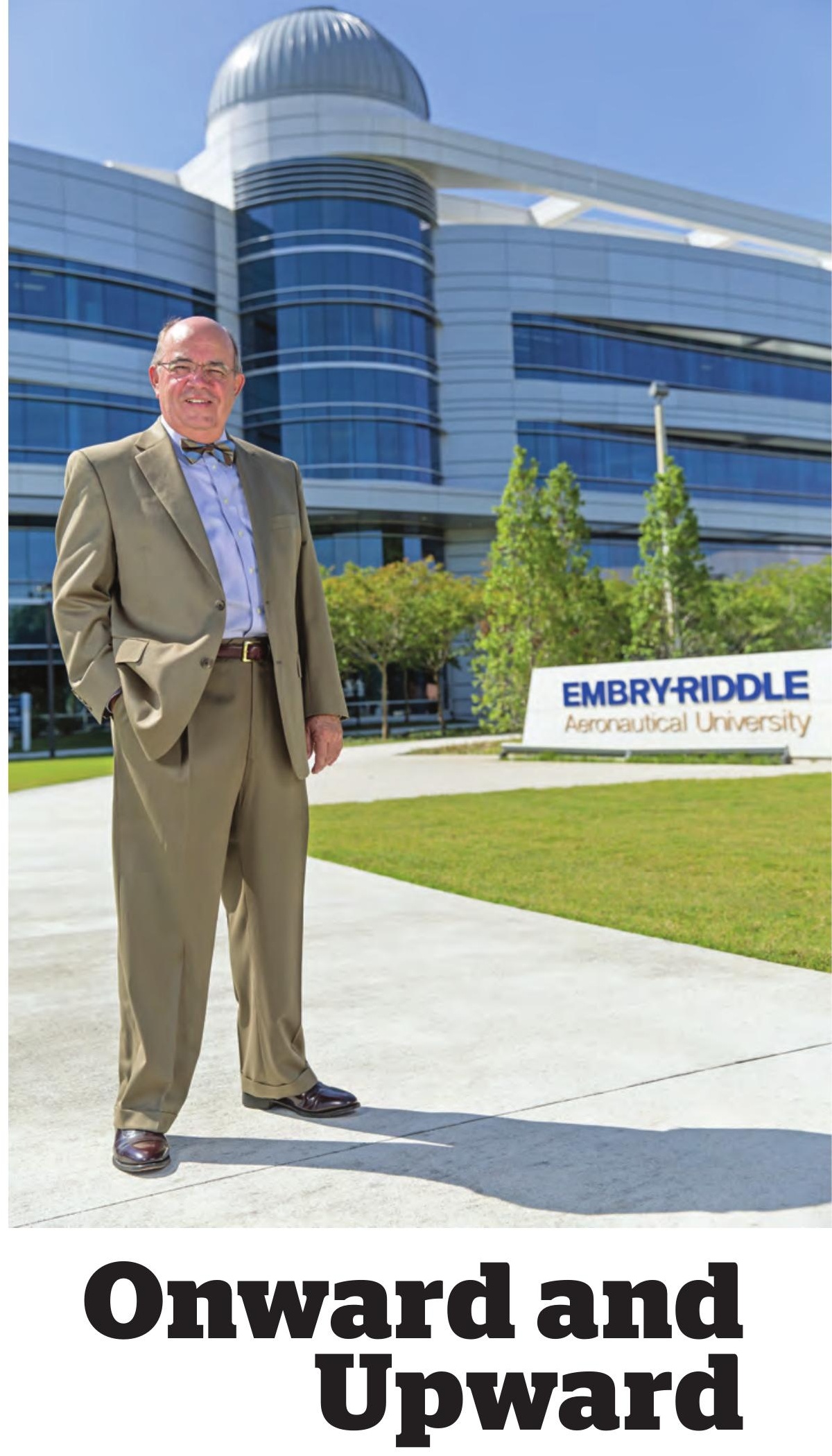

At the end of a decade of leadership, President Emeritus John P. Johnson looks back on an era of innovation and discovery 
service. For me it was important not to move away from teaching and service-because both are critically important-but to strengthen research so that the university could stand strong in all three areas and raise its academic reputation. During the time I served as provost (2003-05), I met with each academic department to establish goals that would strengthen scholarly productivity.

We worked to establish mutual respect, collegiality, civility and good faith consultation that led to positive changes in the criteria for promotion and tenure. Upon discovering that I loved and cared for the institution as much as they did, everything clicked, and the evolution process began.

\section{What has been your proudest achievement at Embry-Riddle?}

The growth of the reputation of the university. Higher education recognizes Embry-Riddle as a strong academic institution with a commitment to excellence in the classroom, public service and the research environment. If you mention Embry-Riddle at any university in the United States, or to colleagues in the global aerospace industry, they know us. When we offer colloquia or workshops, individuals attend from all over the world.

\section{You and your wife, Maurie, have become ingrained in the Embry-Riddle community. What is your fondest memory of your time here?}

All of our best memories have to do with "the EmbryRiddle family" —faculty, staff, students, good friends of the university. Commencements have always been fond moments for us because they remind us what Embry-Riddle is all about. And of course, listening to the AcaFellas sing the alma mater.

\section{What are your plans for retirement?}

We love Embry-Riddle. After many years of interaction with the university, we were blessed to develop a lot of friends in the Daytona Beach area. We will be retiring nearby.

We enjoy the President's Speaker Series that was developed under my direction. My busy work and travel schedule limited our athletic event attendance. Embry-Riddle has over 17 athletic sports programs, with more on the way. Now we will have time to watch the Riddle NCAA Division II transition.

The real decision in our minds for staying in this area is the fact that we will remain close to the university that I had a part in growing.

\section{What message would you like to convey to the} more than 120,000 Embry-Riddle Alumni?

This is an outstanding university. Your diploma and Embry-Riddle's stellar reputation will take you far toward your career goals. Use your degree and represent the university well. We expect great things from you and we know you will be successful. We have no doubt about that. And never forget to "come back home" to visit your campus or to "reach back" to pull up future students with your success.

\section{The Johnson Era}

Imagine a newly installed university president not only losing his office, but the rest of the building around it. This is what John P. Johnson faced in December 2006, when a tornado ripped through Embry-Riddle's Daytona Beach Campus on Christmas morning.

But that storm would set in motion a steady wave of expansion, student enhancement and influence for Embry-Riddle around the nation and the world. Here are some of the highlights:

2008 Embry-Riddle receives the prestigious Collier Trophy for the development and implementation of Automatic Dependent Surveillance-Broadcast technology

2010 Embry-Riddle establishes its first Ph.D.: a Ph.D. in Engineering Physics

Embry-Riddle offers the nation's first Ph.D. in Aviation

The John \& Maurie Johnson Endowed Scholarship for Women is established

2011 Embry-Riddle joins Oak Ridge Associated Universities, a consortium of the nation's top 100 research universities

Embry-Riddle Aeronautical University Asia Campus opens its doors in Singapore (see Asian Expansion, page 18)

2012 Embry-Riddle's Daytona Beach Campus adds a women's softball program

2013 Embry-Riddle's Daytona Beach Campus Athletics program is accepted as a provisional member of NCAA Division II

Embry-Riddle's Daytona Beach Campus adds a women's basketball program

2014 Embry-Riddle receives Level VI accreditation from the Southern Association of Colleges and Schools

University research funding tops \$17 million

The university establishes a College of Security and Intelligence at the Prescott Campus, the first of its kind in the nation

The Daytona Beach and Prescott campuses reach alltime high female student enrollments (19 percent and 23 percent respectively)

Embry-Riddle expands its Aerospace Career Academies to over 40 high school campuses

2015 Embry-Riddle and the University of South Australia partner to expand undergraduate and graduate aviation degree opportunities

Embry-Riddle's Prescott Campus adds a men's basketball program 


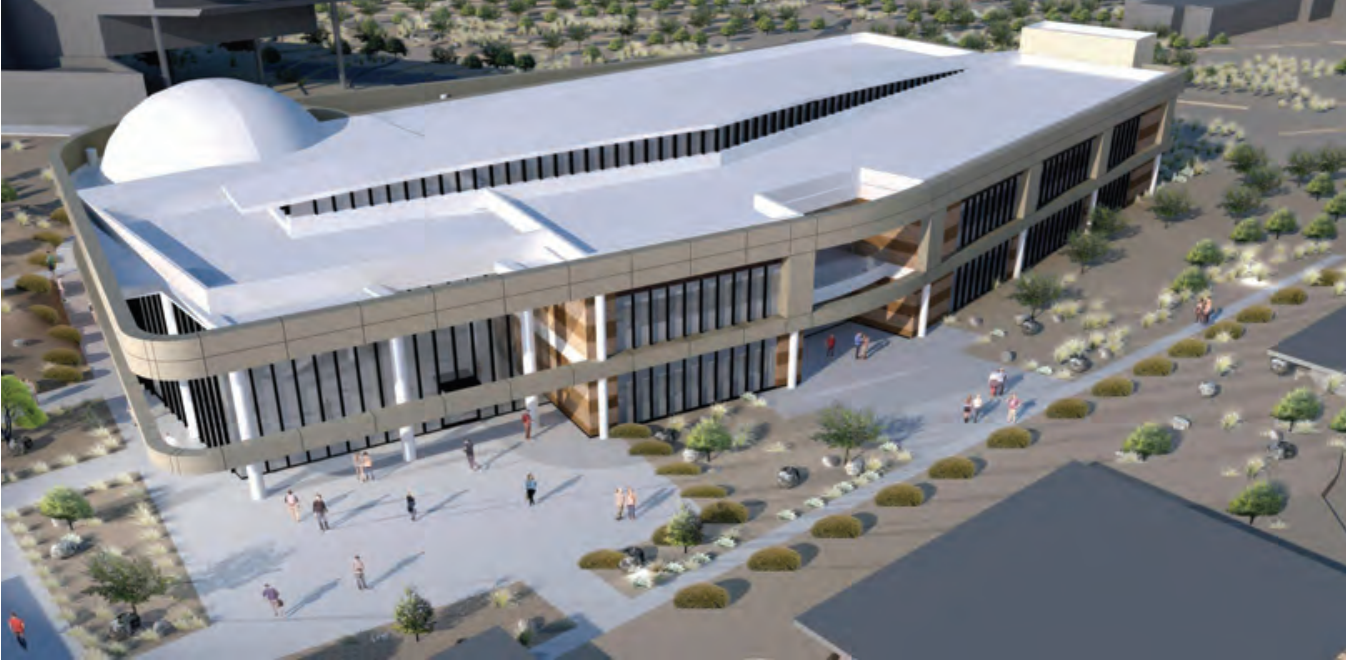

\section{Strength in STEM}

\section{Support grows for a planned education center and planetarium at the Prescott Campus}

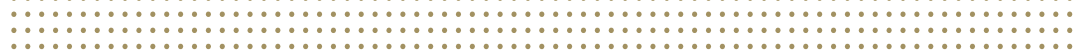

BY MELANIE STAWICKI AZAM

\section{SUPPORT STEM}

You can contribute to STEM education at Embry-Riddle, too. Contact Steven.

Bobinsky@erau.edu for information and for naming opportunities for the STEM Education Center.

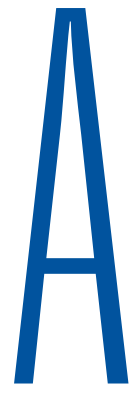

$s$ the Prescott Campus in Arizona continues to expand, support is growing for its newest project, the Prescott STEM Education Center, which will include a planetarium.

Supporters of the estimated $\$ 17$ million facility include Prescott community members, alumni, faculty and staff, and national donors like the Seattle-based Raisbeck Foundation, which has given more than $\$ 1$ million to name the engineering design studio at the center and endow a professorship (see related article opposite page).

"It will become a center for the research and exploration of science and technology for the campus, the community and the region," says Frank Ayers, chancellor of the Prescott Campus.

The state-of-the-art building is aimed at enhancing science, technology, engineering and mathematics (STEM) education at the university and in the community. A robotics lab, multidisciplinary design studio, forensic biology lab, wildlife science lab, 3-D printing lab and energy lab are planned, along with chemistry, optics, research, design, mechanical engineering and general physics labs. Construction of the STEM Education Center, which is slated to be more than
50,000 square feet, is expected to start this year.

The center will also play a vital role in expanding, promoting and enhancing STEM education throughout the community, says Ayers. Its multimedia immersive learning center and planetarium will be open to the public and designed for frequent community use. Area high school and middle school students will be able to visit and explore STEM careers. The learning center and planetarium will augment the Prescott Campus' existing observatory complex, which was recently rated by CollegeRank.net as No. 8 among the top 35 university observatories nationwide.

\section{Building Community}

Local real estate developers Jim and Linda Lee have also contributed to the construction of the STEM Education Center. A wall of honor will be erected inside the building and will display their names, as well as the names of all other major donors.

"The future of the Embry-Riddle Prescott Campus can't be separated from the future of Prescott," says Jim Lee, who sits on a steering committee for campus buildings. "We are very fortunate and pleased to have Embry-Riddle in our community."

Another supporter of the center, Mark LaPole ('84, PC), says he favors the project because it unites all of the STEM education activities under one roof. Previously, these were scattered across the campus. "I also appreciate the outreach goals of the STEM center," says LaPole, whose donation to the project will be matched by his employer, Ball Aerospace. "Opening up the campus for more community and industry involvement will improve the university's profile and strongly enhance the quality and diversity of the student body."

Archie M. Dickey, dean of the Prescott Campus' College of Arts and Sciences, says the STEM Education Center's new biology, chemistry and physics labs will allow the campus to expand the majors it offers to include premedical, preveterinary, forensic biology and wildlife science.

The Prescott Campus faculty and staff are also excited about the project. In all, nearly $\$ 2$ million has been raised.

According to LaPole, all of this support for the STEM Education Center and planetarium is having a noticeable effect on campus spirit. "There is a powerful energy on the campus. Smart, optimistic and the sky-is-not-the-limit thinking is everywhere." 


\section{$\lfloor[$ GACY OF LEARNING}

James Raisbeck and Raisbeck Engineering endow chair at Embry-Riddle's Prescott Campus

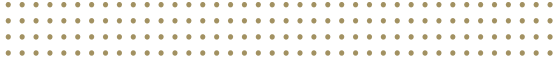

\section{BY MELANIE STAWICKI AZAM}

ames Raisbeck has loved engineering since he was a boy growing up in Wisconsin building soapbox derby cars with washing machine engines.

As a flight engineer in the U.S. Air Force, his enthusiasm for design shifted toward aviation.

"I was hooked, totally hooked on airplanes," says the CEO and board chairman of Raisbeck Engineering Inc. in Seattle, Wash.

That love of airplanes has culminated in a $\$ 1$ million gift from the Raisbeck Foundation to establish the Raisbeck Engineering Design/ Build/Test Endowed Chair at Embry-Riddle. Housed in the Prescott Campus' College of Engineering, the Raisbeck Chair is the first of its kind at the college.

The gift is a continuation of Raisbeck's enduring interest in aviation and education. In 2013, James and his wife, Sherry, helped establish a permanent home for a science, technology, engineering, mathematics (STEM) and aviation-focused high school in the Seattle area, now called Raisbeck Aviation High School.

James says his gift to Embry-Riddle was inspired by the project-based, multidisciplinary education that engineering students receive at the Prescott Campus and the strong leadership of Chancellor Frank Ayers.

"Students have broad insight across, for example, engineering, piloting and management curricula. All of these elements are needed for building skills, which will serve students for a lifetime," he says.

The endowed chair will provide funding for a faculty member who excels in teaching design/build/ test methodologies with teams of students working together on projects. "This synergy of effort will ensure Embry-Riddle aerospace engineers are the best prepared to create the innovative designs of
"Embry-Riddle

Prescott's

undergraduate program stands measurably above others of its type in the way that it integrates various schools and their goals." -JAMES RAISBECK

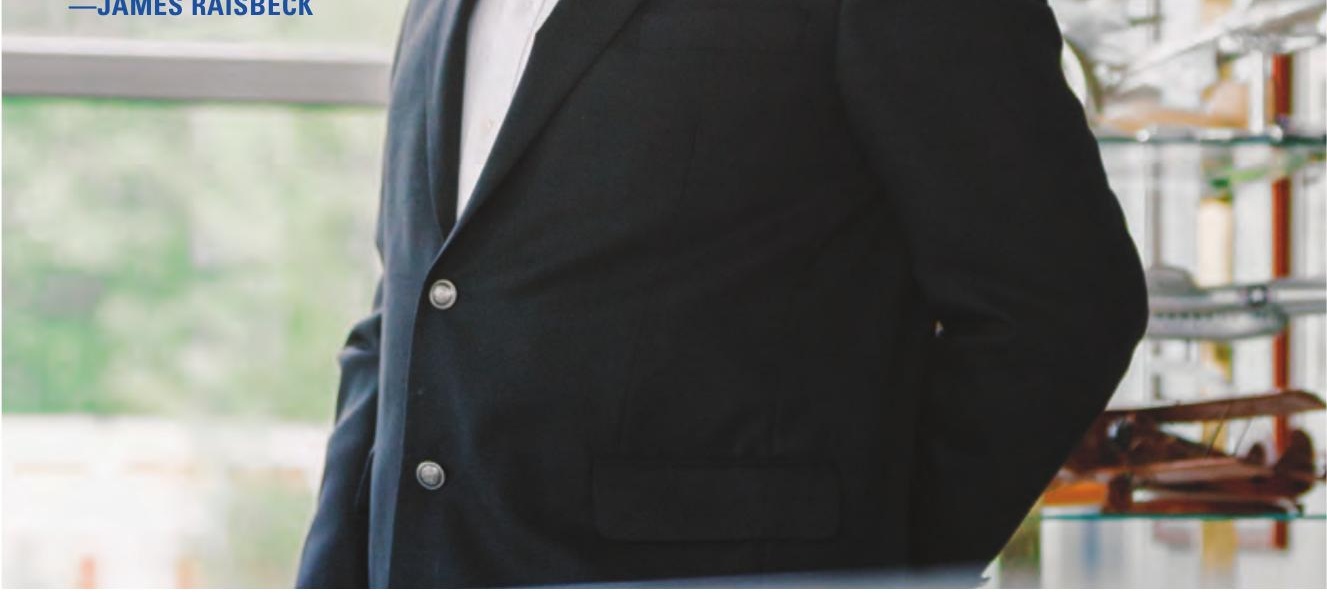

the future," Ayers says. It will also build on the university's strong tradition of engineering education, scholarship and research, and provide a continuum of aviation education that complements the Prescott Campus' current educational ties with Raisbeck Aviation High School in Seattle.

Additionally, the Raisbeck Foundation contributed $\$ 75,000$ toward the building of the new STEM Education Center at the Prescott Campus (see related article opposite page). The Engineering Design Studio at the center will be named in Raisbeck's honor. The state-of-the-art space will allow for hands-on, team-based capstone engineering and multidisciplinary design experiences for students. Raisbeck is also facilitating the donation of a Raisbeck-designed swept blade turbofan propeller from Hartzell Propeller Inc., which will hang on display in the STEM Education Center.

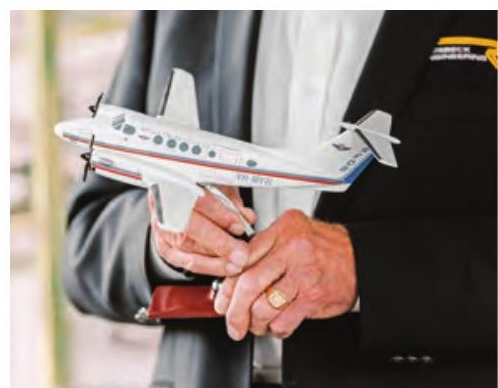

James Raisbeck is an avid supporter of STEM education. Below, he holds a model of Australia's Royal Flying Doctors Service King Air. The Royal Flying Doctors' air ambulance fleet is equipped with Raisbeck's EPIC Platinum packages, including its Wing Lockers. 


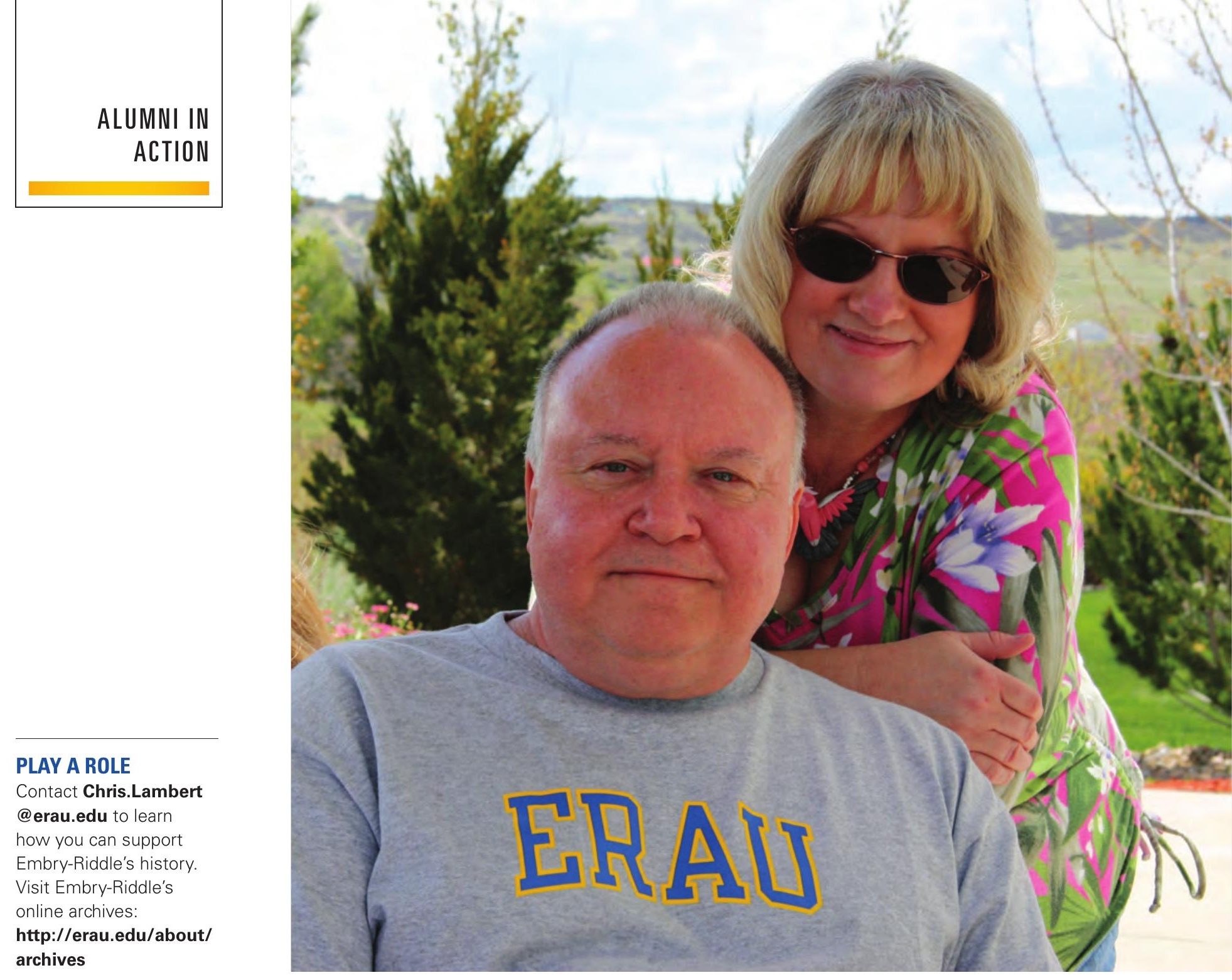

\section{PLAY A ROLE}

Contact Chris.Lambert

@erau.edu to learn

how you can support

Embry-Riddle's history.

Visit Embry-Riddle's

http://erau.edu/about/

archives

BY MELANIE STAWICKI AZAM

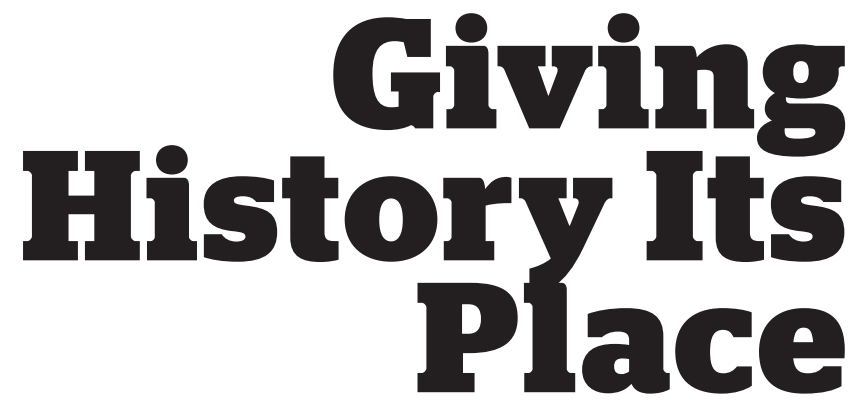

Phil Metz ('81, DB) helps preserve Embry-Riddle's past for future generations

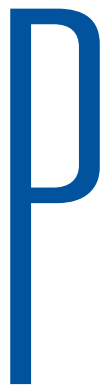

hil Metz ('81, DB) was a sophomore in high school in Pittsburgh when he saw a small black and white ad for EmbryRiddle Aeronautical University in Popular Science magazine.

"I took that ad to my dad and said this is where I want to go to school," recalls Metz, who started at Embry-Riddle in fall 1976

He didn't know it then, but Metz would play a critical role in the formative years of Embry-Riddle's Alumni Association and become an avid supporter of the university's Heritage Project, a fund used to preserve and showcase Embry-Riddle's storied history.

"The history of aviation and the history of EmbryRiddle are forever tied together," says Metz, who is now practice leader for Allianz Global Corporate \& Specialty, a major insurance provider for the aviation industry. "I could have supported scholarships or campus buildings, but I never wanted to put my name on anything. Preserving history may be less popular, but it's important." 
One of Embry-Riddle's first alumni directors, Phil Metz, and his wife, Anne, whom he met while he was a student at the Daytona Beach Campus, are true Embry-Riddle fans. Below: Phil, standing, enjoys ballooning with friends, including Jon Downey ('87, DB), U.S. Head of Aviation for Allianz, kneeling

\section{Campus Memories}

When Metz arrived on campus, the administration building was in an old military barracks building, the parking lot was a former runway and female students were few and far between.

"There were 30 women and every guy on campus knew them by name," says Metz. Spring break, which drew students from across the country to the local beaches, was a welcome distraction, but it also frequently coincided with Embry-Riddle's finals week.

"Spring break was a very popular time for the guys," he recalls. "But so many guys were on the beach every day instead of studying - they didn't come back the next fall."

Metz spent two years in the flight program, but eventually decided to go into the business side of aviation. He graduated in 1981 with degrees in aeronautical studies and aviation maintenance technology. He took a job at Embry-Riddle as an admissions counselor after graduation, and in 1982, he was hired to lead Embry-Riddle's Alumni Association, becoming only the second fulltime paid director for that office.

Five student assistants helped him with everything from annual fundraising to publishing the first alumni directory, and organizing the first campus-sponsored homecoming in 1986. His biggest challenge was a lack of resources, but he says he learned a variety of skills, from graphic design to event planning, that he still uses today.

"It was all trial and error. I had to learn it on the fly," Metz says. "We got a lot done. I am proud of my time there."

\section{Historic Figures}

One of his favorite Embry-Riddle memories was spending time with John Paul Riddle, one of the university's founding fathers. Metz met the renowned aviation entrepreneur in the early 1980s, during one of Riddle's many campus visits as a guest of then-President Jack Hunt.
"He was just a fascinating, fabulous man that I really looked up to and am honored to have met," Metz says. "He'd walk into the University Center and all of the conversation changed. It was like a god walked in."

Another Embry-Riddle icon Metz encountered was then Dean of Student Affairs Bob Rockett. Now dean emeritus, Rockett is a fan of Embry-Riddle history and established and led the Heritage Project in the 1990s. Rockett's passion for Embry-Riddle history soon overflowed to Metz, who began contributing regularly to the Heritage Project and hasn't stopped since. "I wanted to recognize [Bob's] contributions to that project and Embry-Riddle. Bob is a walking Embry-Riddle history book," Metz says.

With an integral role in the early Alumni Association, Metz is part of that history, Rockett says. "He's given his time and money to Embry-Riddle. He's got Embry-Riddle in his blood," Rockett adds. "He left this place better than when he found it."

\section{Lighter Than Air}

Aviation is also part of Metz's personal history-and it consumes his free time. He and his wife of nearly 30 years, Anne, took up hot air ballooning as a hobby about 20 years ago. Metz says he enjoys the peace and quiet of ballooning, but also the thrill of low altitude flying. "I like flying four feet off the ground with the bottom of the basket scraping the scrub brush, scaring all the jackrabbits out," he says with a laugh, speaking about flying in the northern New Mexico desert.

Metz left EmbryRiddle in 1986 to pursue an aviation career. He moved to Atlanta, working in passenger services at Midwest Express Airlines. In 1988, he accepted a job in aviation insurance at USAIG. Nine years ago, he was offered a job at the German-based company Allianz to be part of a team to expand their aviation insurance program to the United States.

"It's been a challenging, rewarding and enjoyable wild ride," he says.

And, aviation has been a common theme throughout. "I love aviation-it's what I do every day," Metz says. "The fact that the university I went to has a big role in the history of aviation and aerospace is exciting, and I think it's important for new students to know that this is where we came from."

\section{"The fact that the university has a big role in the history of aviation and aerospace is exciting, and I think it's important for new students to know that this is where we came from."}

—PHIL METZ ('81, DB) 


\section{ALUMNI NEWS}

\section{MESSAGE FROW THE ALUWWII ASSCCLATION}

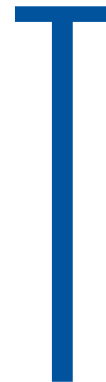

hroughout the past 90 years, one thing has remained constant for Embry-Riddle: aviation. The rumble of reciprocating engines, the riff of a high-speed pass and the thundering concerto of the Space Shuttle at launch - these are the heartbeats around which EmbryRiddle was formed and has endured.

The instruments may have changed over the years, but the response to this music has not. Embry-Riddle alumni gaze skyward when they hear it; they watch, they admire and they dream, even if they've seen the miracle of flight thousands of times before. And, it's not just our pilots who appreciate these sounds. Engineers, aviation business people and financiers, airframe and powerplant technicians, communications and marketing folks, all honor the industry they love and support with a glance up.

It's this shared passion that drives everything Embry-Riddle. The history of aviation and the accomplishments of those who came before inspire our students and alumni to greatness as they envision and orchestrate the future of this ever-evolving arena.

In May, an additional 1,200-plus alumni joined our fold. These new graduates are the aviation and aerospace leaders of tomorrow. We at the Alumni Association couldn't be prouder of our alumni-of all ages. We applaud your efforts every day, and we're tireless in promoting your achievements. You are the Embry-Riddle name. You share in the Embry-Riddle legacy in perpetuity.

Let us know what you're doing, so we can boast about you to your peers - and to the world. And, help us celebrate our 90th anniversary by sharing the stories and photos of your unique Embry-Riddle experience. Visit this link to upload your story and/or view others' memories: alumni. erau.edu/erau 90 .

Embry-Riddle Eagles will continue to strive for and reach new heights for the aviation/aerospace industry. We're excited to see what the next 10, 20, 50 , and even the next 90 years will hold for our great university. We may not be around to see it, but someone who shares our passion will. Keep looking up!

\section{Forever an Eagle!}

Bill Thompson ('87, PC)

Executive Director

\section{CHECK OUT LIFT'S NEW WEBSITE!}

You can read your favorite alumni magazine on your desktop tablet or phone, and get immediate access to video and other web extras. Experience Lift online at lift.erau.edu.

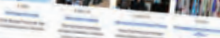

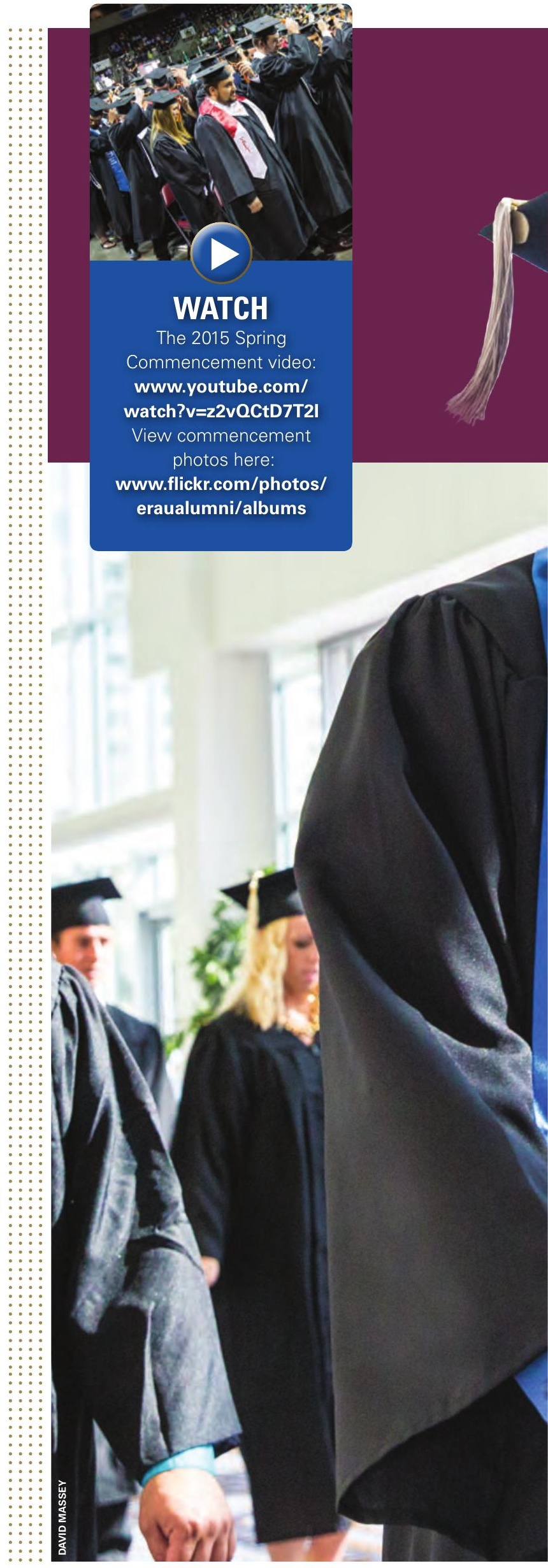

facebook.com/ERAUAlumni

twitter.com/ERAU_Alumni

Search Embry-Riddle Aeronautical

University Official Alumni Group
Join the Eagle Network:

alumni.erau.edu/join

instagram.com/erau_alumni/
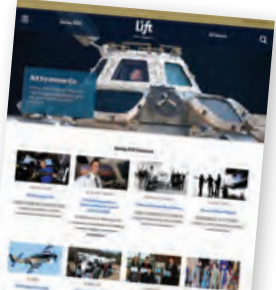


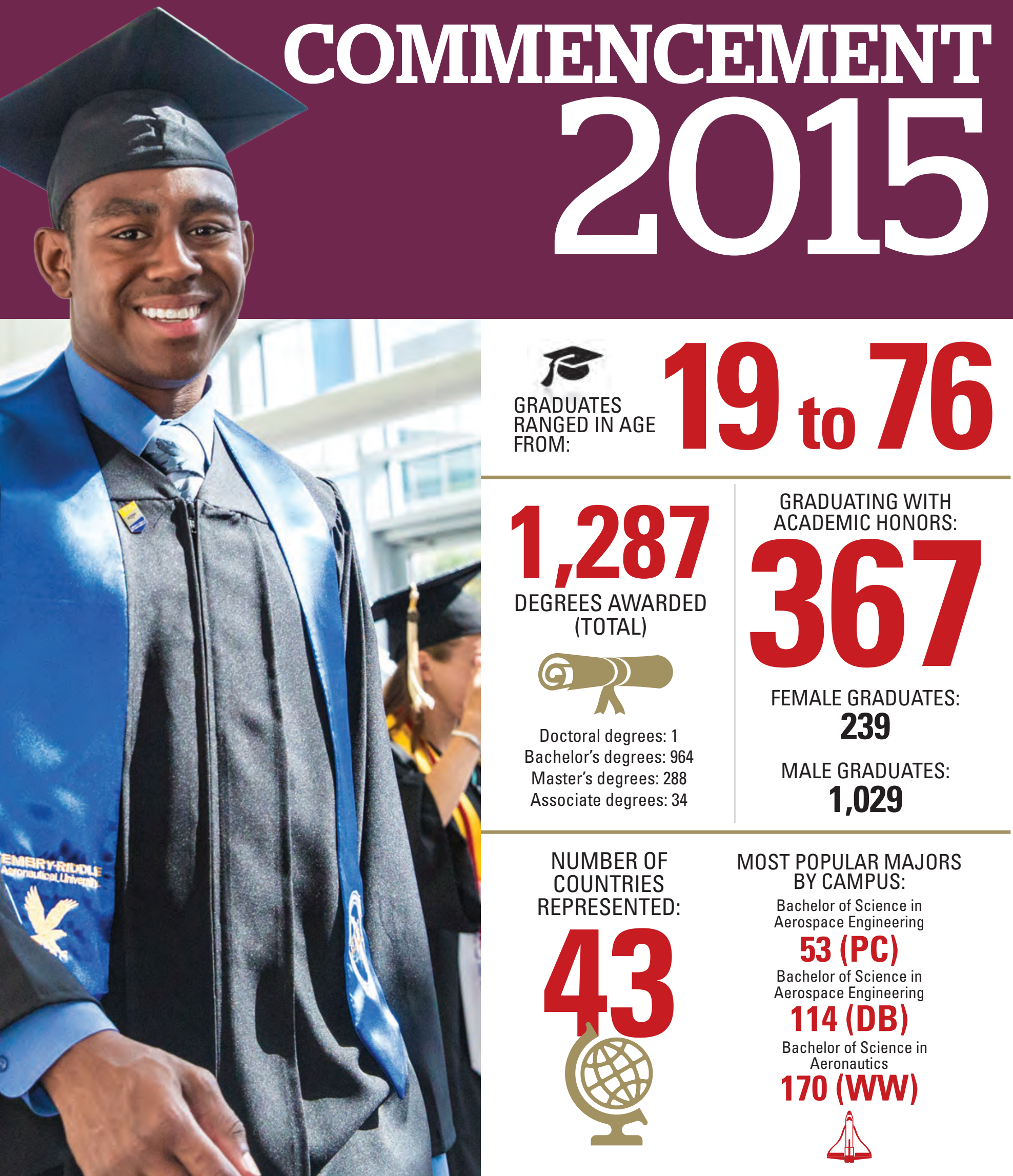

NOTE: INCLUDES ALL MAY 2015 CEREMONIES (PRESCOTT CAMPUS, DAYTONA BEACH CAMPUS, AND WORLDWIDE CAMPUS: SAN DIEGO, CALIF; EUROPE; DAYTONA BEACH, FLA.; AND PRESCOTT, ARIZ.) 


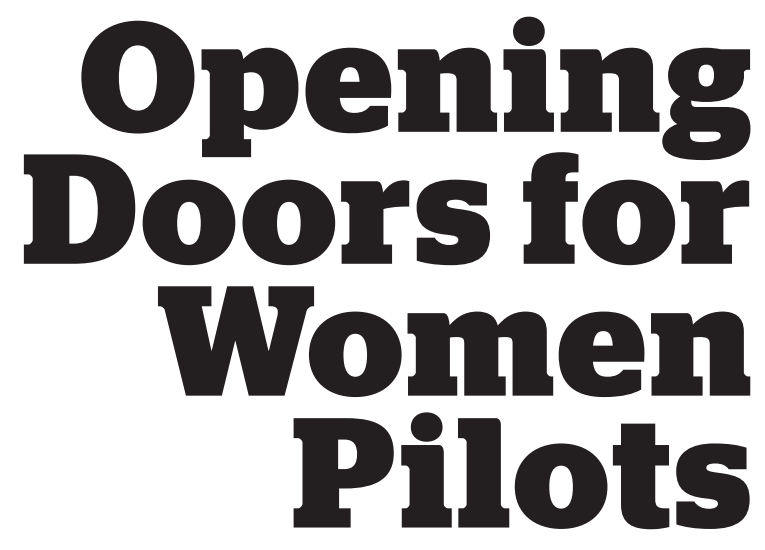

Kathi Durst ('88, WW) leads flight at Dallas/Fort Worth

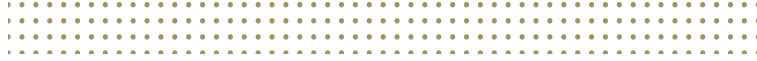

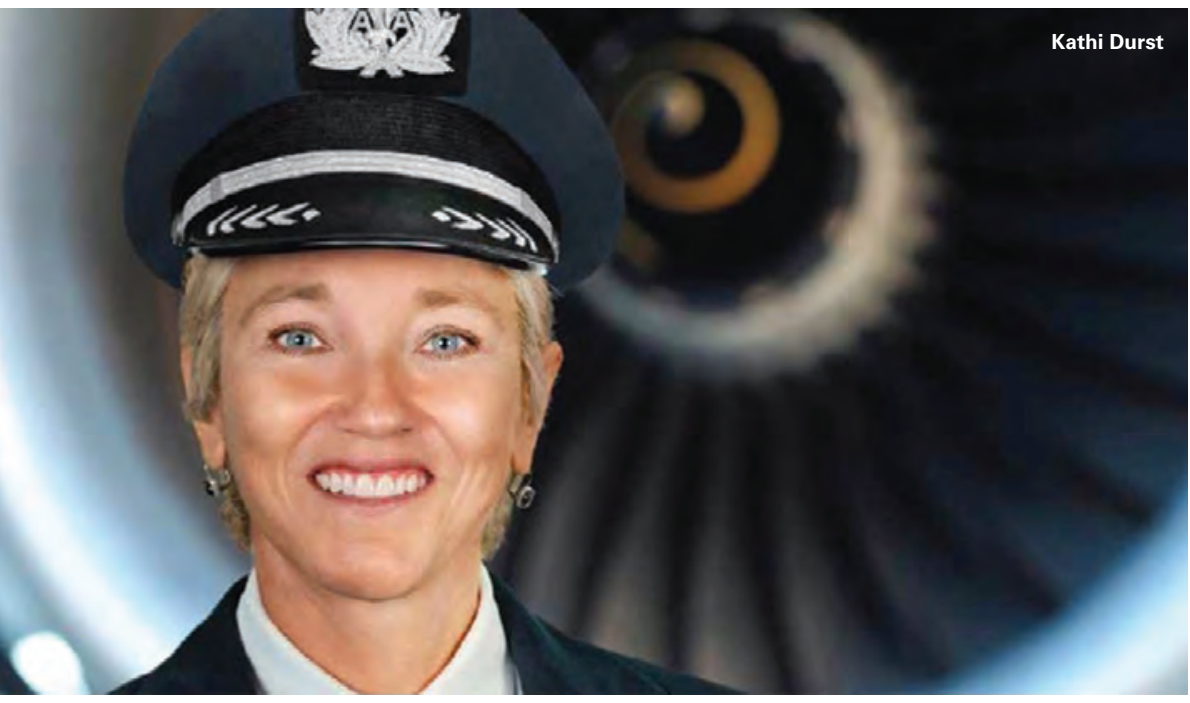

\section{BY MOLLY JUSTICE}

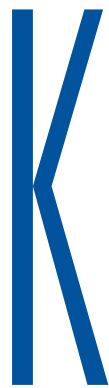

athi Durst ('88, WW) believes in keeping an open mind. She entered the U.S. Air Force Academy with intentions of becoming an orthopedic surgeon. She qualified for fighter pilot training but couldn't participate because she was a woman. She earned a master's degree to advance in the military but ended up leaving the service after seven years.

Now Durst is one of four chief pilots for American Airlines at Dallas/Fort Worth (DFW) Airport-the airline's largest crew base in the world. She also happens to be American's first female chief pilot at DFW and the company's only openly gay chief pilot "Keep all doors open. Pursue all things," Durst says.

\section{On American Airlines}

Before her recent promotion, Durst spent two years as American's first female fleet manager (Boeing 737).
In this role, she worked with pilots to develop training manuals and policies and procedures. She also interfaced with agencies like the Federal Aviation Administration and National Transportation Safety Board and spent time with industry leaders to discuss aircraft design and development.

As a chief pilot, Durst is an advocate for the 3,000 pilots based at DFW. Her job is to listen to the pilots' needs and try to help them in any way possible. She also serves as a liaison between the pilots and other internal departments. Durst has worked other jobs during her 26-year career at American-including check airman on the Airbus A300 and Boeing 737 fleets. And decades after her Air Force flight training, she still loves to fly-although her current position tends to keep her a little more "grounded" these days.

\section{On Education}

While serving in the Air Force, Durst earned her Master of Aeronautical Science from Embry-Riddle Worldwide. "I chose that degree because I wasn't sure I was getting out of the military," she says. In the military, a graduate degree was necessary for advancement.

Once she left the service, Durst didn't initially see the correlation between her graduate studies and her work as a commercial pilot. It wasn't until she became a fleet manager in 2012 that she fully appreciated her master's degree and the management lessons she learned.

"Having that degree definitely helped me later in life," she says. "You just never know."

\section{On Career Advice}

"If you are a helpful, eager person, good things are going to come to you," Durst says.

Experiences such as education, volunteerism and networking have contributed to her success. Many times, these experiences and personal attributes are just as important as a job candidate's technical aptitude, she says.

Over the years, Durst served on the pilot recruitment board. She also mentored young pilots through Women in Aviation International. Durst is active in the industry and belongs to organizations such as the National Gay Pilots Association. In 2014, she was named a recipient of the Earl G. Graves Award for Leadership in Diversity. Honorees are recognized by American for their efforts as leaders in diversity, both at work and in the community.

"At this point in my life, I want to do whatever I can to help the next generation," Durst says. "It's my way of paying it forward in appreciation of women like the World War II Women Airforce Pilots who preceded me and paved the way for my career interests."

Durst is honored by the attention her chief pilot promotion has drawn. At the same time, she's also embarrassed by it. "Day to day, I don't think about the fact that I'm a woman or gay," she says. "All of my life, I've always tried to be a team player, work hard and put my nose to the grindstone." 


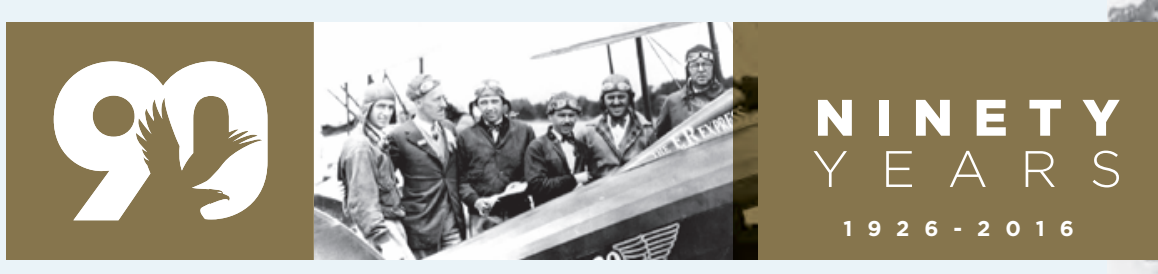

\section{The ERAU of U: 90 Years of Embry-Riddle}

t's your time to reminisce! Help Embry-Riddle celebrate its 90th anniversary (1926-2016) by sharing your memories at alumni.erau.edu/erau90. Read some of our early submissions here.

\section{Big Man on Campus}

During my three years at Embry-Riddle Prescott, it was not uncommon to see John Paul Riddle strolling the campus, often in white tennis shorts and shoes and a preppy sweater. He was still playing tennis in his early 80 s. One day he stopped me outside the library and said, "I want to know what they're teaching you around here, so answer these questions: Do you know who Lincoln Beachey was?" I replied, "Yes sir, he was the first pilot to master the loop." Seemingly impressed, he continued, "Do you know who Barney Oldfield was?" I responded, "Yes sir, he was a race car driver who raced his car against Beachey in an airplane." John Paul smiled, shook my hand, and said, "You're getting a good education here," and he headed to the courts.

Michael Ehl ('83, PC)

\section{Buck Up Bucko}

I remember hearing the high-pitched scream of Professor Bolton driving his "jet powered" car around campus. I remember the Clark Gable look-alike that said jets were a passing fancy, but recipes would be around forever. I remember Pop Alonso getting on the [Beechcraft] D-18, bucking up, undoing his pants belt and buckle and then saying, "OK, Bucko, are we going to do this or what?" And most of all, I remember all of my fraternity brothers at Alpha Eta Rho that are all industry leaders and have been my brothers for all these years.

Retired U.S. Air Force Maj. Tom Berg ('70, DB)

\section{Fond Memories}

The best years of my life were 1982-1986.

Brigitte Lakah ('87, DB)

\section{Skyfest Salute}

Although I'm listed as a Worldwide Campus graduate, I spent seven semesters at the Daytona Beach Campus, and in my heart I'm a Daytona Beach graduate. The memory

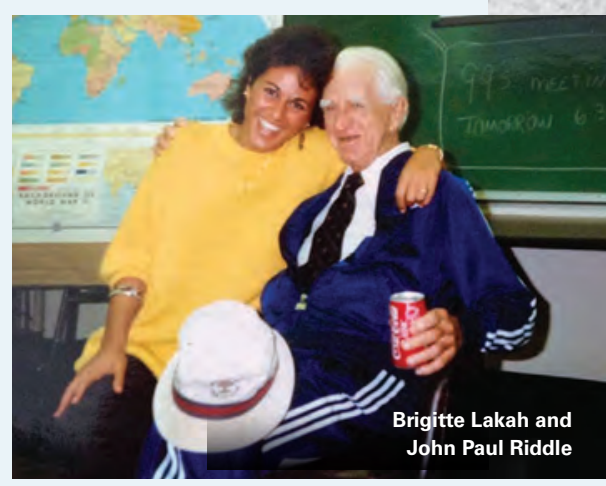

I want to share took place at the spring 1986 Skyfest air show. On the last day of the show, Embry-Riddle was celebrating its 60th anniversary with a picnic on the University Center grounds. There were fewer buildings on campus then, and the view of the airport was unobstructed. Many students, faculty and staff had gathered to watch the military aircraft depart, most of which had requested and received permission to do maximum performance takeoffs. The best part was the takeoff performed by two AV-8 Harriers. The two aircraft departed normally, but then they circled the airfield and made a low pass down the center of the runway. They slowed as they came abeam the school ... and stopped! Holding their position above the runway, they pivoted toward the school and dipped their noses in a bow to the school, then they turned back down the runway centerline and roared off in horizontal flight. Perhaps the AV-8s aren't as fast as the F-15s or F-16s that departed DAB that day, but what they did brought us all to our feet shouting at the top of our lungs. We could have received no better tribute. Happy 90th Anniversary, Embry-Riddle. And thanks for the opportunities you have given all of us. Jeffrey Miller ('86, WW)

\section{Resident vs. Resident}

I was a freshman residential adviser (RA) for Hall 3 (2011-2012) and for Hall 4 (2012-2013).
John Paul Riddle

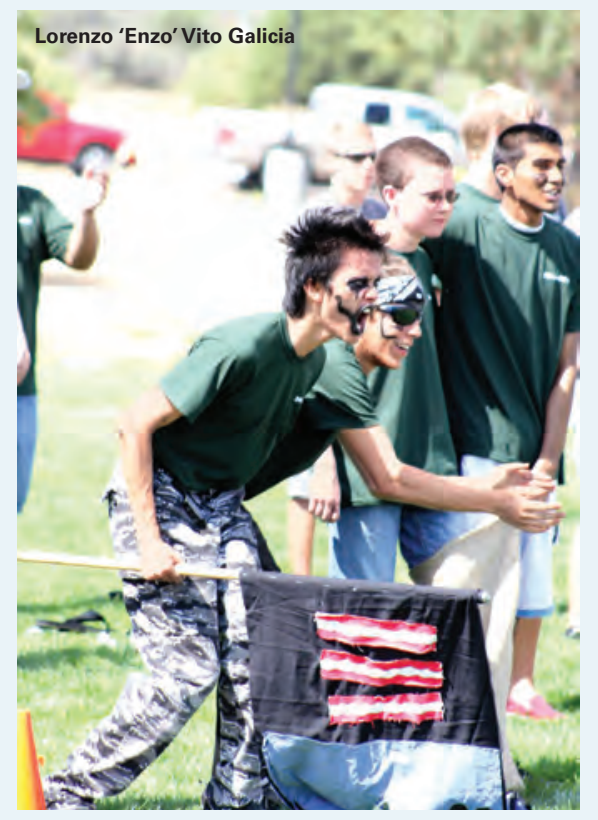

At the end of freshman orientation we hold an event called "The Olympiad," which pits freshman halls against each other in field games in a battle for supremacy and awesomeness. The other RAs and I came up with the tradition of face painting the residents and creating chants and battle cries, which still continues today. The 2011-2012 mascot for Hall 3 was the Bacon Shark, and the 2012-2013 mascot for Hall 4 was the Bacon Badger. Both halls came in first place for their respective years.

Lorenzo "Enzo" Vito Galicia ('15, PC) 


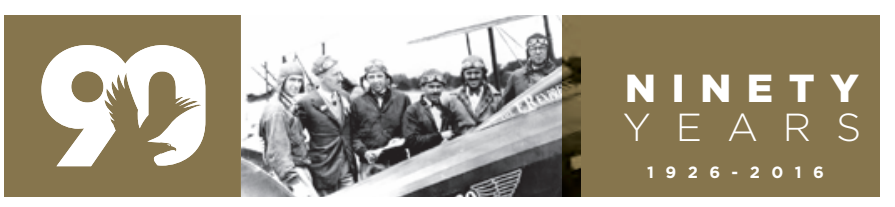

\section{SAVE THE DATE}

\section{OctoberWest Homecoming Weekend and Wings Out West Air Show}

PRESCOTT, ARIZ.

\section{THURSDAY, OCT. 1}

- Industry/Career Expo

- eagleNIGHT
FRIDAY, OCT. 2

-26th Annual Alumni

Golf Tournament

- Alumni Awards Dinner

- Fireworks
SATURDAY, OCT. 3

- Wings Out West Air Show

- Fly-in, Static Display

- Pancake Breakfast

- Blue \& Gold Bash

\section{Alumni Homecoming Weekend and Fly-in DAYTONA BEACH, FLA.}

\section{WEDNESDAY, OCT. 7 \\ - Industry/Career Expo \\ - Alumni Networking \& Awards Reception}

FRIDAY, OCT. 9

- Alumni Return

to Classes

- Campus Tours

- eagleNIGHT Hangar Party
SATURDAY, OCT. 10 - Fly-In,

- Static Display \& Breakfast

\section{Register today: alumni.erau.edu/homecoming}

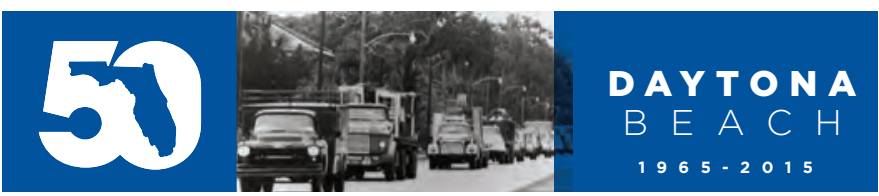

For the most up-to-date list of events, visit alumni.erau.edu/events.

SEPT. 5

Worldwide Campus

Commencement

Ford Island (Oahu), Hawaii

SEPT. 12

Worldwide Campus

Commencement

Seattle, Wash.
OCT. 3

Worldwide Campus

Commencement

Dallas, Texas

0CT. 15-17

FLYING Aviation Expo

Palm Springs, Calif.

\section{MARKYOUR CALENDAR \\ for 2015 \\ Industry/Career Expos:}

THURSDAY, OCT. 1

Prescott, Ariz.

WEDNESDAY, OCT. 7

Daytona Beach, Fla.

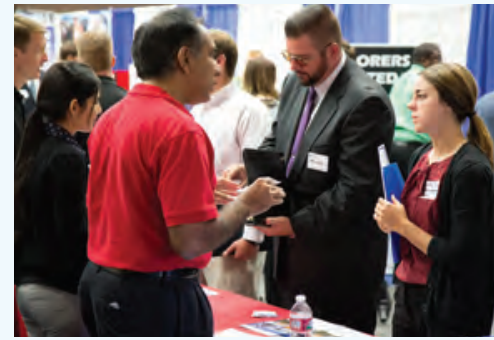

For additional information and job resources:

careerservices.erau.edu.

Lifelong Learning

EMBRY-RIDDLE PROFESSIONAL EDUCATION COURSES

$\begin{array}{ll}\text { Aircraft Crash Survival } & \text { Unmanned Aircraft Systems } \\ \text { Investigation and Analysis } & \text { Seminar } \\ \text { Sept. 21-25, 2015 } & \text { Dec. 8-10, 2015 } \\ \text { Prescott, Ariz. } & \text { Daytona Beach, Fla. }\end{array}$

Airline Network Planning

Oct. 2-3, 2015

Daytona Beach, Fla.

Unmanned Aircraft Systems

Applications, Operations and

Support: Key Topics of Industry

Oct. 14-15, 2015

San Diego, Calif.

Aviation Logistics \& Supply

Chain Management

Nov. 9-10, 2015

Daytona Beach, Fla.

Aviation Safety Management

Systems: Application and

Implementation

Nov. 17-19, 2015

Daytona Beach, Fla.

Fall 2015 Certificate of

Management in Aviation Safety

Series:

OSHA \& Aviation Ground Safety

Oct. 19-23, 2015

Daytona Beach, Fla.

Aviation Safety Program

Management

Oct. 26-30, 2015

Daytona Beach, Fla.

Aircraft Accident Investigation and Management

Nov. 2-6, 2015

Daytona Beach, Fla.

Certificate courses are also available online in Aviation Risk Management and Corporate Aviation Management. A Project Management Professiona ${ }^{\circledR}$ Exam Preparation course is also offered.

To register and for additional information and course offerings: proed.erau.edu.

NoV. 17-19

National Business Aviation Association Business Aviation Convention \& Exhibition

Las Vegas, Nev.

DEC. 12

Prescott Campus Commencement

Prescott, Ariz.
DEC. 14

Daytona Beach Commencement Daytona Beach, Fla.

MARCH 10-12, 2016

27th Annual International Women in Aviation Conference Nashville, Tenn. 
surveillance and reconnaissance (ISR) flight operations manager, and then director of ISR flight operations. His aviation career began in the Army, where he flew rotary and fixed-wing aircraft at locations around the world. Retiring from the Army after 28 years, he then flew the DC-8 and DC-9,

To share your Class Notes with Lift and your fellow alumni, join Embry-Riddle's online community at alumni.erau.edu/join today; or submit your announcements through email to eralumni@erau.edu. For guidelines, visit alumni.erau.edu/notes_guidelines.

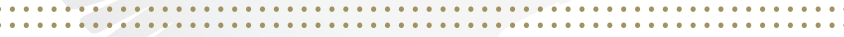

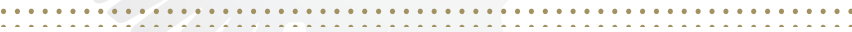

\section{Career News}

\section{0s}

Brooks Lovelace ('50, MC, Nondegree) was awarded a Bronze Medal at a ceremony in Washington, D.C., in December 2014, in recognition of his Civil Air Patrol service along the Georgia coast during World War II.

\section{0 s}

Arthur Jacobs ('74, DB), CEO of Valkyrie Consulting Group, has opened offices in Singapore and Melbourne, Australia. Jacobs did two tours in Vietnam as a helicopter pilot and spent two years as the aviation officer for the 10th Special Forces Group. He has an MBA in Marketing Management \& Organizational Psychology from the University of Florida. He and his wife and three children currently reside in Brentwood, Tenn. He is a life member of both the Disabled American Veterans and the Special Forces Association.

Mori Hosseini (HonDoc '13; '78, '79, ' $82, D B$ ) is the 2015 recipient of the Herbert M. Davidson Memorial Award for Outstanding Community Service. The Community Foundation of Volusia \& Flagler, a division of the United Way of Volusia-Flagler Counties, presents the honor to individuals demonstrating a career of exceptional service. Hosseini is chairman and CEO of Intervest Construction Inc., chairman of EmbryRiddle Aeronautical University's Board of Trustees and chairman of the Board of Governors for the State University System of Florida.

Darrell Pope ('78, WW) was promoted to vice president of flight operations at Dynamic Aviation. Pope joined Dynamic Aviation in 2009 as a pilot, and was promoted to intelligence, and was a captain on the 767 for Airborne/DHL Express.

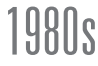

Ed Thayres ('80, PC) is a G550 captain for EJM based at the airport at Teterboro, N.J.

John Mangona (' 81, DB) is vice president and chief information and compliance officer for Saratoga Hospital in Saratoga Springs, N.Y. He has been with the organization since 1995. Previously, he worked with McDonnell Douglas and Edward Jones in St. Louis, Mo.

Steven Reed ('81, DB) was hired as the western U.S. division head of sales by United Realty, a sponsor of commercial real estate alternative investment programs.

\section{Russell A. Sibley Jr. ('81, DB)}

is a lawyer in private practice in Tampa, Fla. Sibley practices primarily in the areas of business litigation and exceptional student education. He was recently awarded the AV Preeminent ${ }^{\circledR}$ peer review rating from Martindale-Hubbell.

Wayne Norris ('82, DB) retired after 33 years of commercial flying, including spending the last 10 years as a 767 captain for ABX Air. He is now operating Norris English Pub and Brewery in Liberty, Ind.
Jim Kennedy (‘82, DB) was appointed Hawaiian Airlines' director of base maintenance. Kennedy brings more than 25 years of maintenance, engineering and mechanical experience to Hawaiian Airlines.

\section{Robert DeGennaro ('83 DB)}

retired from the Federal Aviation Administration, where he was employed for 26 years. During that time, he was at John F. Kennedy International Airport (JFK) as an air traffic controller and then became a traffic management coordinator. He finished his career as a supervisor at Westchester Tower in White Plains, N.Y. He recently started a new career as the ground management program manager at JFK.

Rick Trusis ('83, DB) was appointed vice president of Mid-Cabin Programs at Gulfstream Aerospace Corporation.

Art Schmidt ('84, DB) is senior vice president, head of airline marketing for Aviation Capital.

Stephen Blanchette (' $86, \mathrm{PC}$ ) has relocated to the Software Engineering Institute's offices in Arlington, Va.

Kristin Incrocci ('86, DB) founded Sarasota-based Lift Air in October 2014. The business is an air taxi service that flies from Sarasota to virtually any destination throughout Florida.

David Lincoln ('89, DB) is currently working for Delta Air Lines, flying the Boeing 777-200LR. He is based in Detroit, Mich., and resides in Henderson, Nev.

Lee Anne Tait ('89, WW) was appointed vice president of quality at Gulfstream Aerospace Corporation.
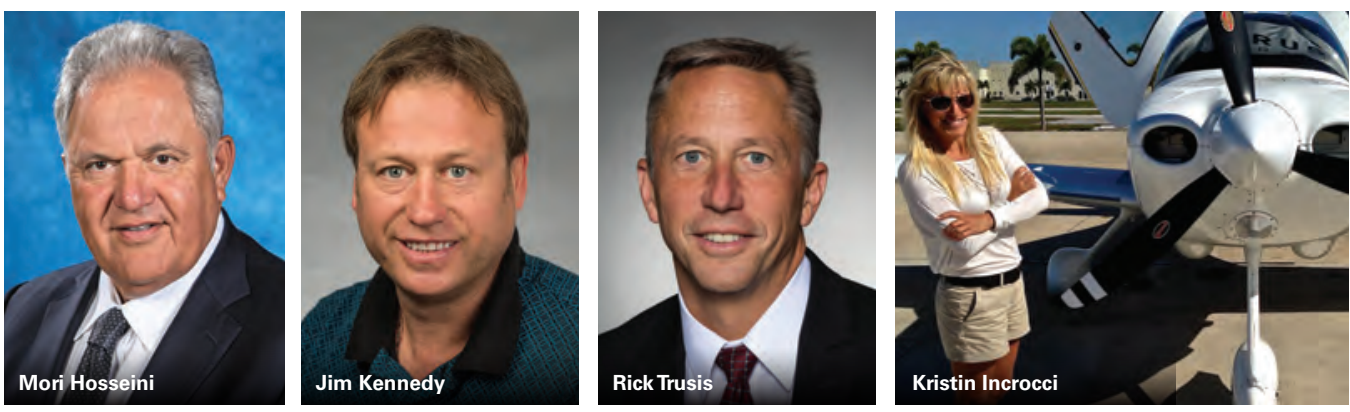

\section{CAMPUS LEGEND \\ MC Miami Campus \\ DB Daytona Beach, Fla. \\ PC Prescott, Ariz. \\ WW Worldwide Campus \\ BFTS No. 5 British Flying \\ Training School}



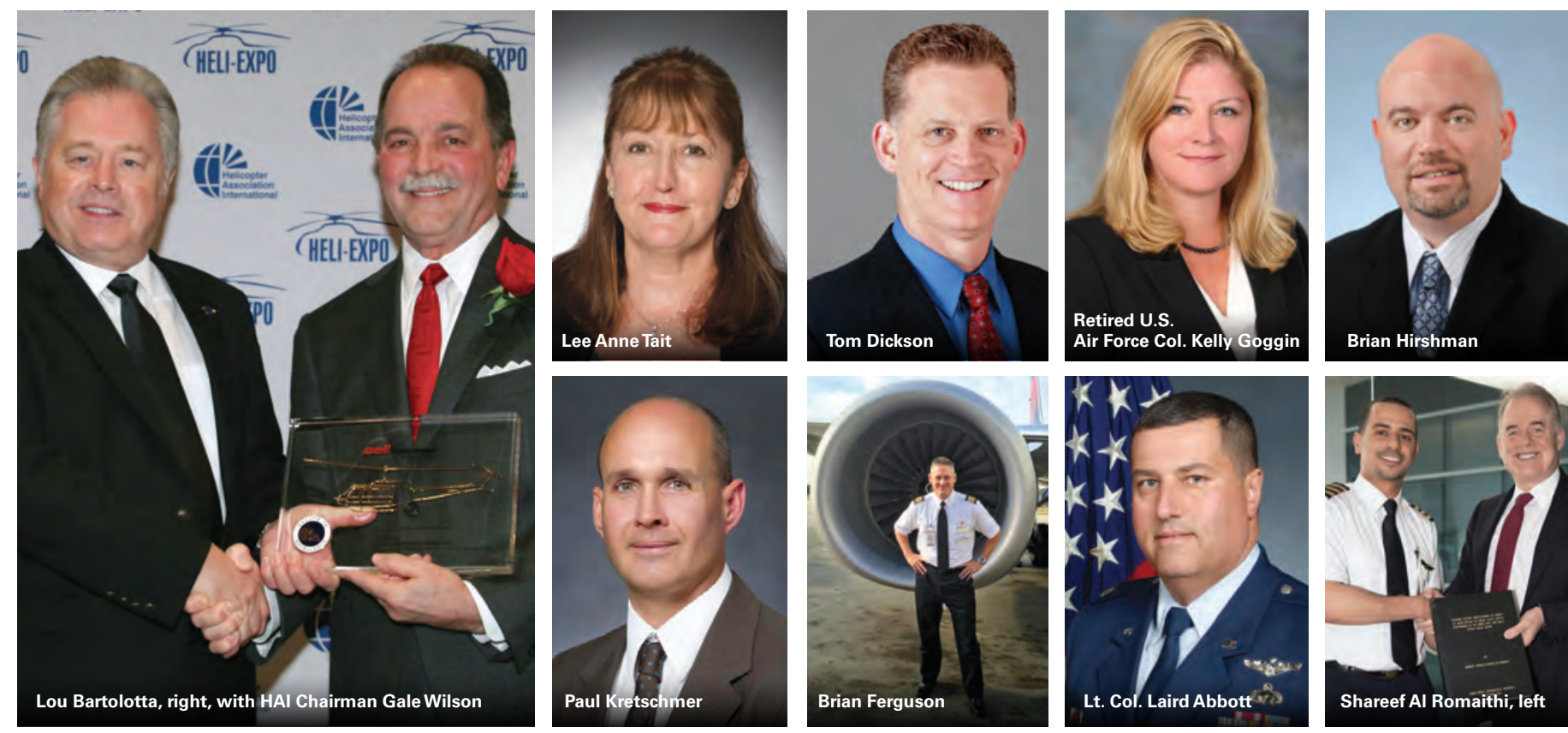

\section{0s}

Brian Hirshman ('90, DB) joined Aviation Technical Services as president, effective May 1, 2015. Hirshman has more than 25 years of experience working in the aerospace and aviation industry, most recently as senior vice president of operations at Southwest Airlines, and as managing partner at AeroConsulting Partners LLC

Tom Dickson ('90, PC), who is vice president of information technology at Sabre Systems Inc., was named a 2015 Top IT Pro by the Philadelphia Business Journal.

Justine Ruff ('90, DB) is director of airports for the Midland International Air \& Space Port in Midland, Texas.

Eric Hockman (‘91, DB) was named partner of Weiss Serota Helfman Cole \& Bierman, a 58-lawyer firm located in South Florida.

Paul Kretschmer (' $92, D B$ ) is a preflight and delivery quality manager on the 787 Program for The Boeing Company in Everett, Wash.

Cedric Rockamore ('92, ‘96, WW) was promoted to vice president and will oversee operations at American Airlines' hub in Philadelphia.
John Parker ('92, WW) is vice president and general manager of the Integrated Logistics and Modernization division for Northrop Grumman Corporation's Technical Services sector.

Rana Das ('92, DB) is the divisional vice president and general manager of AMETEK MRO Florida, a unit of AMETEK Aerospace \& Defense.

George R. Macri ('92, ‘ 94 , WW) is a quality engineer at The Boeing Company. He works on the Space Launch System Heavy Launch Vehicle at the Michoud Assembly Facility in New Orleans, La. In December 2014, he celebrated his five-year service anniversary with Boeing

Brian Ferguson ('93, DB) recently began employment as a pilot for Delta Air Lines. He flies the Boeing 737NG out of Los Angeles.

Col. Thomas Hanley (' $94, D B$ ) is the senior National Guard adviser to U.S. Southern Command. The State Partnership Program supports theater engagement across 27 countries in the Caribbean, South America and Central America.

Lt. Col. Laird S. Abbott (‘95, PC) assumed command of Defense Contract Management Agency Boeing Long Beach, where he is responsible for contract administration services for the $\mathrm{C}-17$ Globemaster III program. He arrived from Robins Air Force Base, where he served as the chief program manager for $\mathrm{C}-17$ Sustainment. Abbott will be the final commander at the Boeing Long Beach Plant, which will close after C-17 production ends in 2015.

Bhavesh Patel ('95, PC) is Denver International Airport's (DEN) chief revenue officer, executive vice president in charge of the Commercial, Concessions and DEN Real Estate business unit. Patel previously was the director of airport concessions at Tampa International Airport in Florida.

John Michel ('96, WW) is president and chief strategy and innovation officer of MV International. Michel joins MV after a 26-year career in the U.S. Air Force, where most recently he led NATO's 14-nation effort in Afghanistan to build the $\$ 6.7$ billion Afghan Air Force.

\section{Jeremy Baran ('96, PC) was pro-} moted to lieutenant colonel in the U.S. Army Reserve and is leaving the Joint Enabling Capabilities Command - Joint Planning Support Element to take command of the 319th Combat Service Support Battalion in Harlingen, Texas.

\section{Retired U.S. Air Force Col. Kelly} Goggin ('96, WW) is now director of business development for Constellation West, an information technology services provider. With over 26 years of U.S. Air Force and operational military experience,
Goggin was most recently the senior director of legislative liaison, U.S. Cyber Command.

Lou Bartolotta ('97, WW) was honored on March 4, 2015, with the Helicopter Association International's (HAI) 2015 Bell Helicopter Lifetime Achievement Award. Bartolotta earned his helicopter wings in the U.S. Army in 1970, which was followed by a one-year tour in Vietnam. He then flew commercial helicopters in pre-revolution Iran and later in the North Sea out of Scotland. He enjoyed a 30-year career in senior management positions in the helicopter manufacturing sector. The last 26 years were spent with AgustaWestland (AW) in roles including vice president of sales for North America, vice president of marketing, executive vice president of sales and marketing for North and South America, and senior adviser. Bartolotta retired in 2014 from AW and is now principal of L.P. Bartolotta \& Associates LLC, a vertical lift consultancy. View link for award presentation: www.youtube.com/ watch?v=m1WRnUr_Dvc.

Bryant Francis ('98, DB) is the airport director of the Long Beach Airport in Long Beach, Calif.

James "Steve" Gordon ('98, WW) was promoted to associate director of corporate procurement for the Army and Air Force Exchange Service 

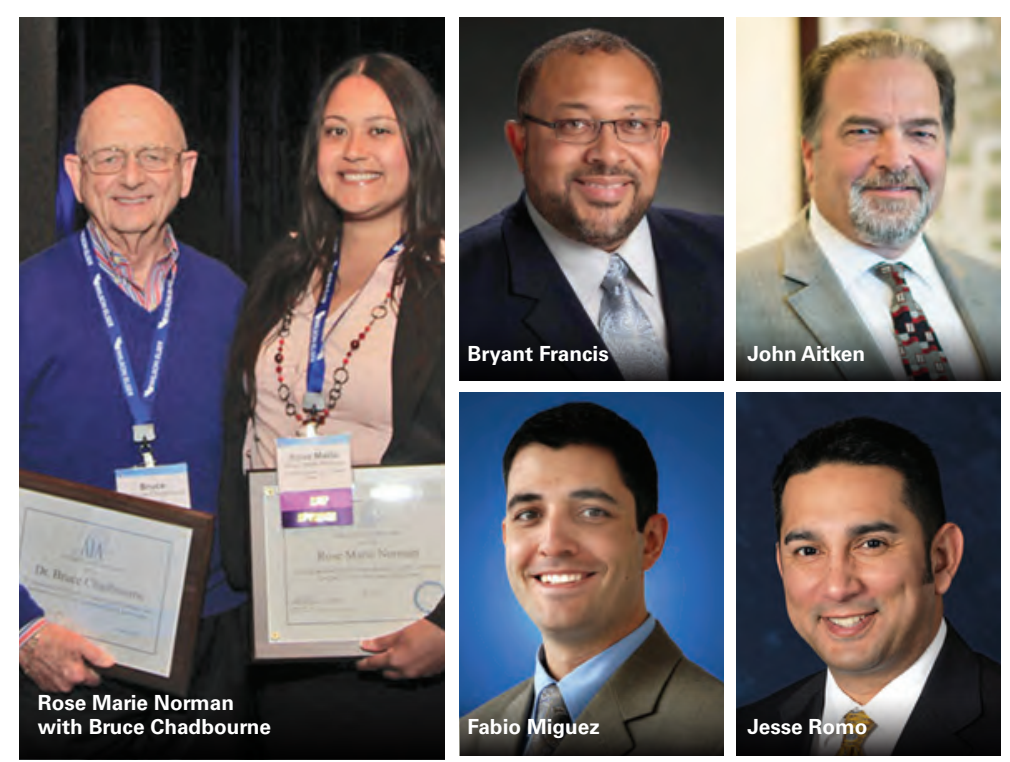
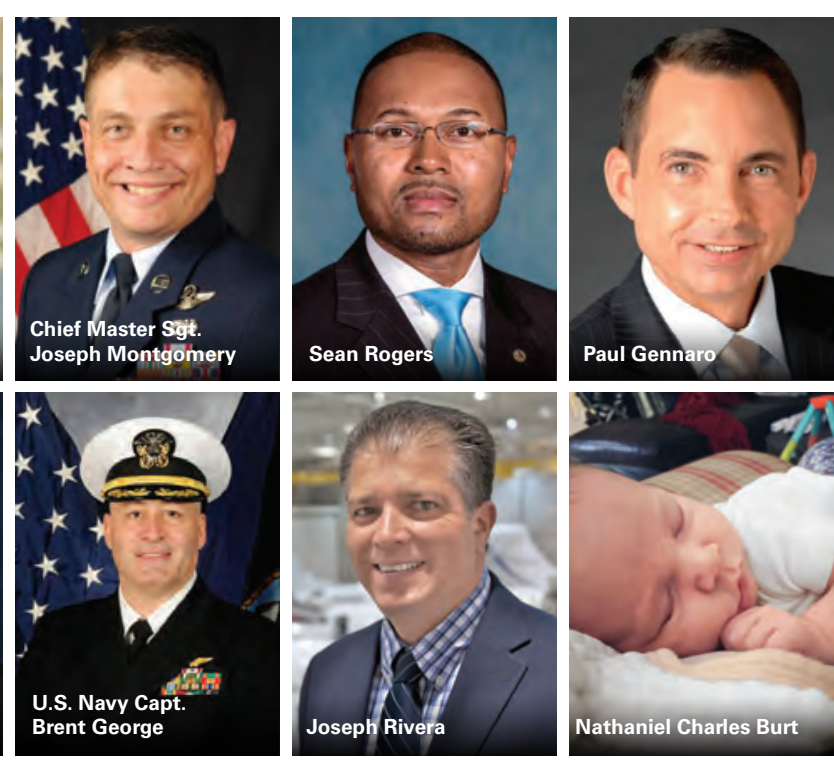

at its headquarters in Dallas, Texas. He began civilian service with the exchange after retiring in 2003 from the U.S. Air Force.

John Aitken (‘99, WW) was promoted to assistant director of aviation at Mineta San José International Airport in San José, Calif. Aitken has served as acting assistant director of aviation since 2013 , and as deputy director of aviation - operations at Silicon Valley's airport since 2002. He has worked there since 1993.

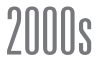

\section{Chief Master Sgt. Joseph}

Montgomery ('01, WW) was named command chief for the Kirtland Air Force Base's 58th Special Operations Wing in New Mexico.

Sean Rogers, Ph.D. ('01, ‘02, DB) joined the faculty at Cornell University's School of Hotel Administration on July 1 . He is teaching courses in human resources, labor relations, and management in hospitality and aviation.

\section{Katadah Abdul Hameed Zaman}

$(' 01, D B)$ is managing director of the International Institute for Strategic Studies' Middle East branch.

\section{Benito Avendano ('02, DB) was} selected for Lockheed Martin's Program Manager Talent Initiative, where Level 4 and 5 program managers are groomed for senior program manager and/or executive roles.
Matthew C. Kahn ('02, DB; '04, WW) is director of the Operations and Client Center at Delta Private Jets, Delta Air Lines' wholly owned private jet subsidiary.

Kerry McGovern ('02, WW) was appointed a regional sales manager for Securaplane Technologies, a supplier of avionics products for business, commercial and military aircraft. He is based in Miami, Fla., with responsibility for the Southeast and Central United States.

Paul Gennaro ('03, WW) is senior vice president of corporate communications and chief communications officer for Voya Financial.

Fabio Miguez ('03, DB) was promoted to regional operations manager for FlightSafety. He continues to serve as manager of the company's learning center in Columbus, Ohio.

Jesse Romo ('04, DB) was named airport director for the city of Manhattan, Kan., effective April 27, 2015. He is responsible for the daily management and operations of Manhattan Regional Airport in Kansas.

Tim Koczur ('04, WW) is the deputy power manager for the Grand Coulee Dam in Grand Coulee, Wash.

Shareef AI Romaithi ('05, '06, DB; '14, WW), a 31-year-old Etihad Airways first officer, has become the first Emirati to obtain a Ph.D. in Aviation from Embry-Riddle Aeronautical University, which also makes him the youngest holder of this degree in the world. He is pictured with James Hogan, Etihad Airways' President and CEO.

Bobby McMasters ('05, WW) was named interim dean of the College of Business at Embry-Riddle's Worldwide Campus, effective Jan. 2, 2015. A longtime faculty member, McMasters is an associate professor of business administration based in Las Vegas, Nev.

\section{U.S. Navy Capt. Brent "Buddha"} George ('05, DB) retired on Sept. 1, 2014. Completing a 25-year career as a U.S. Naval Test Pilot School graduate and aerospace engineering duty officer, George served in carrier aviation, operational and developmental test and evaluation, and aircraft acquisition, production and overhaul positions. He also served multiple tours as a portfolio manager leading spacecraft design and acquisition at the National Reconnaissance Office. Following his Navy career, George founded Buddha George Consulting Inc., a Northern Virginia-based national security management and leadership consulting firm.

William D. Steininger-Holmes ('05, PC) was selected for promotion to the rank of major in the Air Force. He currently serves as chief of the Atlas $\mathrm{V}$ Avionics and Electrical Systems Branch with the Space and Missile Systems Center at Los Angeles Air Force Base.

Rose Marie Norman ('06, DB) recently earned the Aviation Insurance Association's Certified Aviation
Insurance Professional (CAIP) designation. Norman is an aviation broker at Aon Risk Solutions and is based in Dallas. Coincidentally, Embry-Riddle Worldwide Campus adjunct faculty members Bruce Chadbourne and Alex Wells taught Norman's final CAIP course and administered the certification exam. Both Chadbourne and Wells were recognized with achievement awards at the AIA Annual Conference in May, where Norman also received her official certification.

Jessica (Fekete) Tracey ('06, DB) was hired at Delta Air Lines and is flying the MD 88/90 as a first officer. Previously, she spent seven years at Republic Airlines.

Joseph Rivera ('06, '11, WW) is director of international operations at Gulfstream Aerospace Corporation. Based in Savannah, Ga., Rivera is responsible for oversight of Gulfstream's three international service centers in Beijing; Luton, England; and Sorocaba, Brazil. Luton and Sorocaba are currently in operation, while Gulfstream Beijing is expected to begin operations soon.

Jesse Quirion ('07, DB) is the public works director for the city of Menlo Park, Calif.

\section{Air Force Lt. Col. Clayton Percle} ('07, WW) became the first activeduty pilot to $\log 1,000$ flight hours in the F-22 Raptor. This was achieved in February 2015, at Joint Base Elmendorf-Richardson. 
Richard J. Mosler ('08, PC) is the airport duty manager at SeattleTacoma International Airport (SEATAC). He started working at Paine Field in Everett, Wash., in the operations department in November 2008. From there, he transitioned to working as a superintendent of operations at Los Angeles International Airport. He began working as a duty manager at SEA-TAC in December 2012.

$2010 s$

Rhett Morgan ('11, DB) is director of Ailevon Pacific Aviation Consulting LLC, based in Dallas. He was previously senior manager of network planning and performance for Southwest Airlines.

Melanie Chatham ('12, PC) completed her flight control training and is now employed by the International Space Station at NASA-Johnson Space Center in Houston.

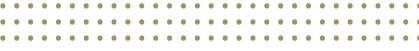

Family News

19ดीs

Nathaniel Burt ('98, DB) and his wife, Suzanne, welcomed their second child, Nathaniel Charles "Charlie" Burt, on May 1, 2015. Charlie joins his big sister Katherine at home in York, Pa. Nathaniel is a principal software engineer and program manager at Exceptional Software Strategies in Linthicum, Md.

\section{$2000 \mathrm{~s}$}

Phil Balliet ('02, DB; '14, WW) and his wife, Katey, welcomed their first child, Sydney Lynn, on June 27, 2014. Phil is an aviation program manager supporting the Federal Aviation Administration in Washington, D.C.

Johann Schrell ('08, DB) and Sarah Schrell ('09, DB) welcomed a happy baby boy, Finley Robert Schrell, on Feb. 25, 2015. Johann is a research and development engineer and Sarah is a thermodynamics engineer at UTC Aerospace Systems in San Diego, Calif. 2010s

Tim Martin ('10, DB; ' $13, W W$ ) and his wife, Megan ('10, DB), welcomed their daughter, Brooklyn Ann, on April 15, 2014. Tim is a senior quality engineer on the F-35 Support Equipment program at Lockheed Martin. Megan works as a benefits consultant for NTA Life. The family resides in Fort Worth, Texas.

\section{Eric McBride ('13, WW) and}

Danielle McBride welcomed a son, Jacob Allen McBride, on Sept. 18, 2014, in Melbourne, Fla. "Jacob is a healthy and thriving baby boy and we are so very blessed by this miracle!" Eric is a first officer for JetBlue Airways and the family resides in West Melbourne, Fla.

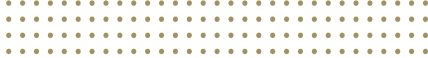

\section{Marriages/ Engagements}

\section{0s}

Thomas "Sid" Mann III ('61, MC, Non-degree) and Sandra Trivino were married on Feb. 13, 2015, on a locomotive at the Florida Railroad Museum maintenance facility in Parrish, Fla., where Mann is a volunteer. They honeymooned in Bogota, Columbia. The couple reside in Sarasota, Fla.

\section{$2010 s$}

Capt. Bryan Beasley ('10, PC) is currently an F-16 Flight Lead with the U.S. Air Force stationed at Homestead Air Force Base in Florida. In 2011, he married Kelsy Goswick, originally of Prescott, Ariz.

Ashley Getz ('10, PC) and Clay Buerger ('09, DB) were married on Oct. 4, 2014, in Silt, Colo. Ashley is an office manager and physical therapy aide at PRC Physical Therapy, and Clay is a calibration technician for Encana Oil \& Gas.

Michael Pyrch ('11, DB) and Courtney Hergert united in marriage on Nov. 23, 2014, in Andalusia, Ala. The couple is currently stationed at
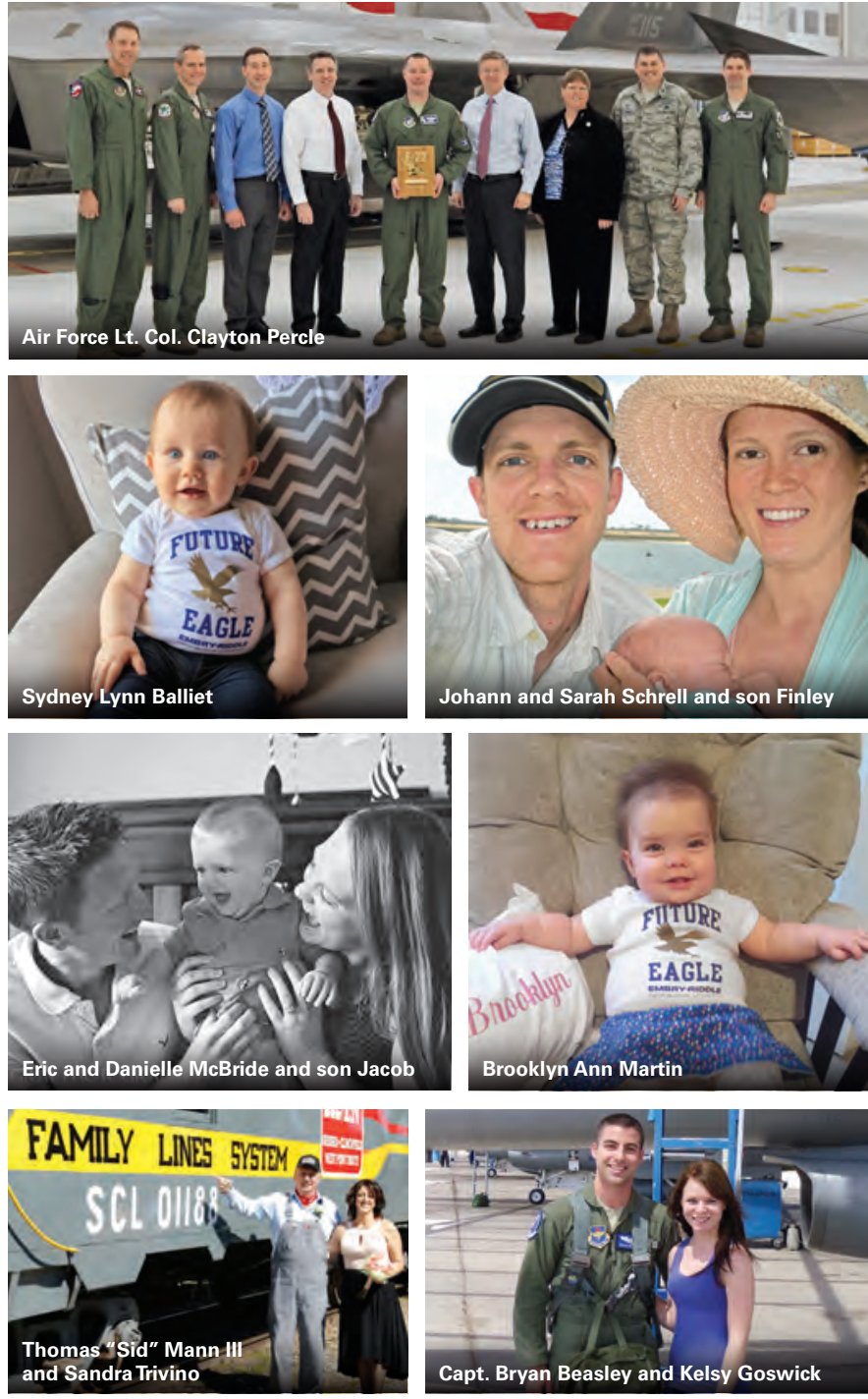

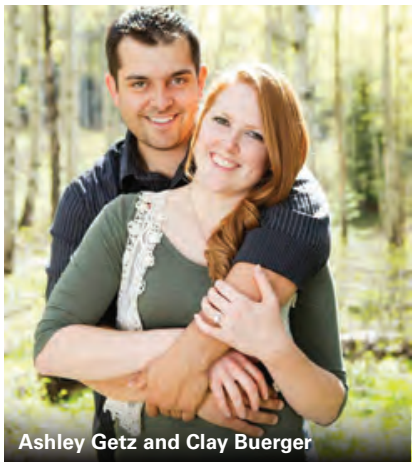

Vance Air Force Base in Oklahoma, where Michael is attending undergraduate pilot training.

Rohit Narasimhan ('11, '13, DB) and Srinisha "Nisha" Shankar ('11, DB) were married in May 2015 in New Jersey. The couple first met in 2007 at Embry-Riddle's Daytona Beach Campus. They reside in Houston, Texas.

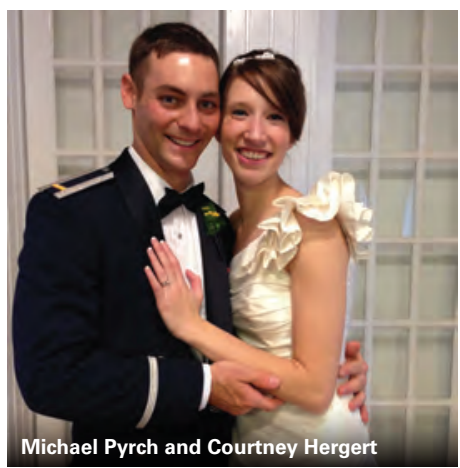

James ('14, DB) and Adriana

(Osegueda) Kimmel ('14, DB) were married on Jan. 19, 2015, at Walt Disney World in Orlando, Fla. The couple met right before their freshman year in 2010 at the Accepted Student's Day at the Daytona Beach Campus. They live in Everett, Wash., where they both work for The Boeing Company as stress analysts. 


\section{EAGLE AUTHORS}

\section{ON THE BOOKSHELF}

Andrea Coppick ('93, PC)

authored Georgia Goes to Lunch, an illustrated children's book. The story is based on the author's first ride in a small airplane and how it inspired her dreams of becoming a pilot. Coppick is an airline pilot and a philanthropist. She established the Dare to Dream Scholarship through Women in Aviation International in 2009, which assists women seeking advanced aviation training. "From that first airplane ride, I've always known I wanted to fly. Every flying adventure has been part of an incredible journey, and I love to share that passion with young children," she says.

Melvin M. Vuk, Ph.D., retired associate professor for Global Security and Intelligence Studies at the Prescott Campus, is a contributing author of the Encyclopedia of U.S. Intelligence, a two-volume set published December 2014, by CRC Press. A reference source for government agencies and research libraries, the encyclopedias also high-

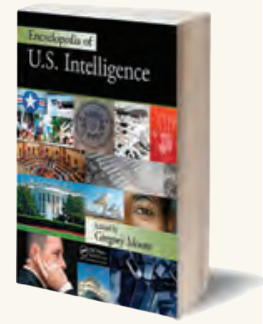
light the development and practice of intelligence in the United States. In addition to a print version, the set is available in a continually updated online version. Authored by former intelligence professionals and scholars, the encyclopedia is the first definitive work to record U.S. intelligence, its history, prominent figures and intelligence agencies, and to feature key events that have shaped the present U.S. intelligence environment.

Retired NASA astronaut and U.S. Air Force Col. Ronald J. Garan Jr. ('95, WW) authored The Orbital Perspective: Lessons in Seeing the Big Picture from a Journey of 71 Million Miles, published in 2015. Drawing on his experience living and working on the International Space Station and viewing the grandeur of Earth from space, Garan's book functions as a call to action for people to lay

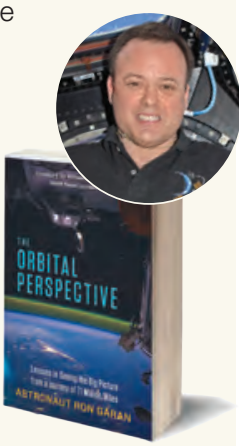
political and cultural differences aside to collectively care and feed planet Earth and its people.

Kenneth O. Jenkins ('11, WW) authored Resilience: Stories of Courage and Survival from Aviation Disasters, published in April 2015. The book explores the personal stories of airplane crash survivors and family members.

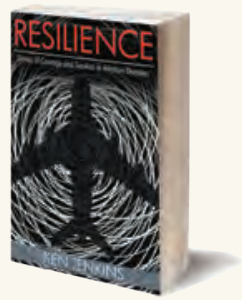

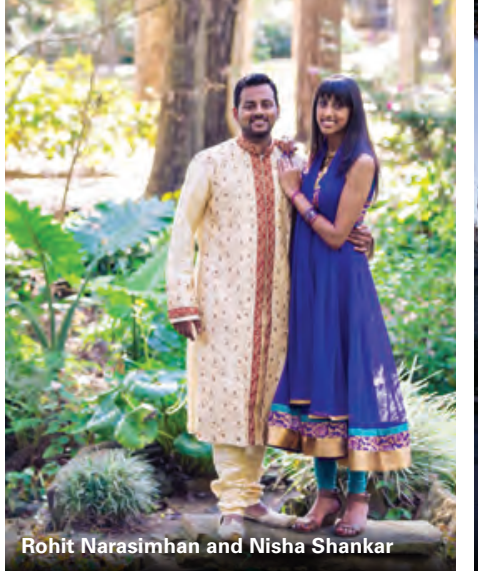
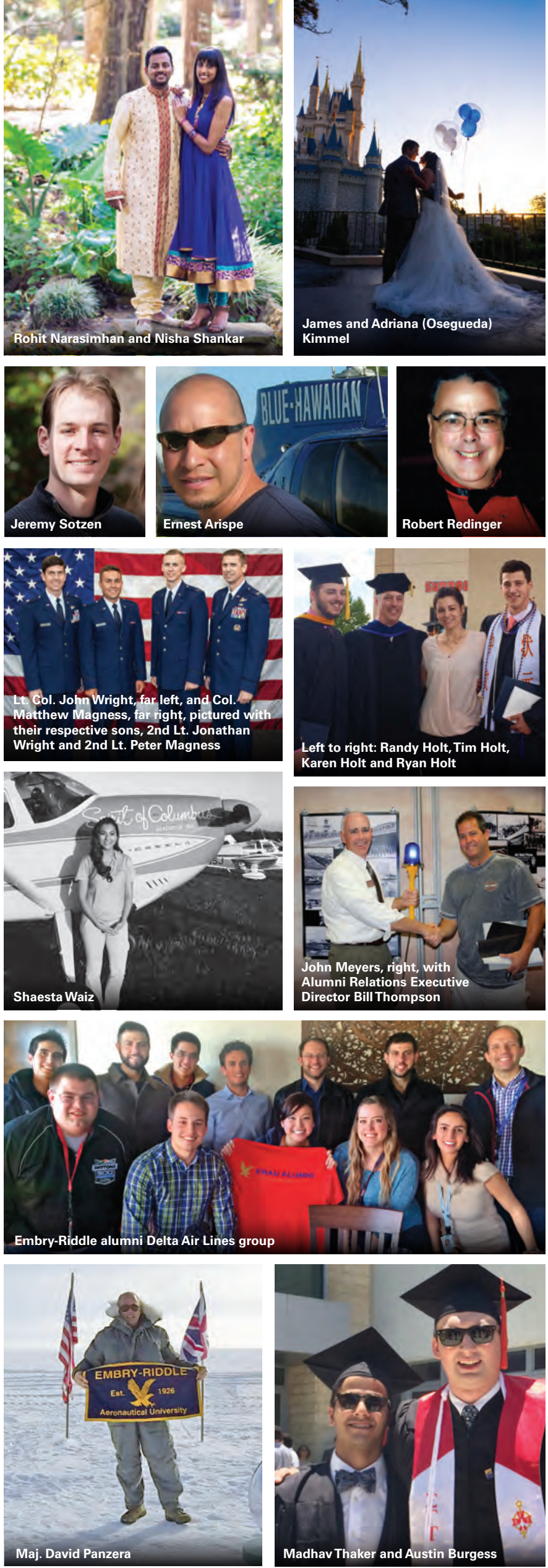
He regularly spends two months a year in Antarctica supporting the efforts of the International Scientific Community through direct support to the National Science Foundation (NSF), Office of Polar Programs. His unit is the single point provider for heavy airlift in the world for the NSF. View the video of his visit here: http://youtu.be/ MVNSvzhv FU.

Laura Smith-Velazquez ('00, '06, DB) is one of 100 finalists selected by Mars One for a future mission to begin colonizing Mars.

Tim Holt ('01, ‘06, WW), director of STEM Programs at the Embry-Riddle Worldwide Campus, presented both of his sons, Randy and Ryan, with their Embry-Riddle degrees at the May 2, 2015, Prescott Campus commencement. Also present was Tim's wife of 25 years and his sons' mother, Karen.

A group of Embry-Riddle graduates who work for Delta Air Lines in Atlanta, Ga., recently got together for lunch. Pictured are, left to right, back: Pablo Guerrero ('05, WW); Mazen Hammoud ('11, DB); current student/ intern Mateo Tobar; Andri Oosja ('07, $D B$ ); Mahmoud Khatib ('06, '08, DB); Sam Hammoud ('10, DB); Juan Forero ('05, DB); front: Jonathan Rabidou ('12, DB); Ehren Biggers ('11, PC); Natsu Okiyama ('07,' '10, pilots in the United States. performed the near-space dive. Ernest

Ery-Riddle pays tribute to our Eagles who have passed. Death notices are published online and in Lift as they are received/reported to the office of Alumni Relations. Send notifications to eralumni@erau. edu. For an up-to-date list, visit alumni.erau.edu/passings

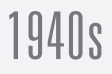

Gilbert S. Guinn ('41, BFTS, Non-degree)

Apr. 30, 2014
Carl T. Pflanzer ('56, MC, Non-degree)

Nov. 4, 2014

\section{0s}

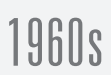

Albert E. Isaacs ('67, DB, Non-Degree)

Feb. 21, 2015

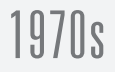

Clarence E. O'Bryan ('72, DB) Feb. 23, 2015

James A. Baerwolf ('73, DB)

Aug. 3, 2014
$D B)$ Kalena Glover ('13, PC); and Andrea Palacios ('10, DB).

William Bayliss ('07, '14, PC) piloted the Goodyear Blimp over Super BowI XLIX, held Feb. 1, 2015, at the University of Phoenix Stadium in Glendale, Ariz. He also piloted the blimp during Race Week for the 2015 Daytona 500 in Daytona Beach, Fla. Bayliss is one of 10 Goodyear Blimp

Michael Abebe ('08, DB) and two other entrepreneurs recently launched a Kickstarter campaign to promote their product design, Jungle Bowl. Abebe is an aerospace design engineer for The Boeing Company in Seattle, Wash.

A trio of Embry-Riddle alumni are members of the Stratospheric Explorer (StratEx) team that made history in October 2014 with a record-breaking, near-space dive from a high-altitude balloon at 135,890 feet. Avid skydiver and Google executive Alan Eustace Arispe ('10, WW), Jeremy Sotzen ('07, DB) and Robert Redinger ('87, WW) are among those who were nominated for the 2014 National Aeronautic Association's Robert J. Collier Award for their contributions to the StratEx project.

John. 0. Thompson ('75, DB)

Nov. 4, 2010

Shaesta Waiz ('10, '14, DB) participated in a memorial service honoring the life of famed aviatrix Geraldine "Jerrie" Mock on April 22, 2015. Mock became the first woman to circumnavigate the world solo in 1964. She died on Sept. 30, 2014, at the age of 88. Waiz met Mock in 2014. "She gave me insights about her trip 51 years ago," says Waiz, who is planning a round-the-world trip of her own for 2016. http://dreamssoar.com/ about-shaesta/.

Classmates Austin Burgess ('14, DB) and Madhav Thaker ('14, DB) launched a tech company called LetsHang LLC, which features a mobile app that allows users to meet people in their area who enjoy the same activities.

Axel Garcia Burgos ('15, DB) was accepted into a joint two-year master's degree program between MIT and the Skolkovo Institute of Science and Technology (Skoltech) in Moscow.

Longtime friend of the university, Helen Wessel, celebrated her 90th birthday on July 4, 2015. Fondly known as the "Face of Art at EmbryRiddle" for her transformative gifts of art to the university, Wessel was born in Cincinnati, Ohio. She flew with her late husband, Robert Wessel, at Lunken Field, the birthplace of the Embry-Riddle Company.

Bryan W. Schafer ('79, DB) May 22, 2015

1980s

Professor Emeritus Grover Frederick "Fred" Mirgle ('81, DB) Daytona Beach Campus' Department of Aviation Maintenance Science July 4, 2015

Gaylord K. Vasconcellos ('81, WW) Jan. 31, 2015

Jerry L. Brantley ('83, WW) Jan. 19, 2015 1990s

Marty W. Ogburn ('96, WW)

Dec. 19, 2014

200กs

Jessica E. OImstead ('00, PC)

Mary B. Thomas ('00, ’05, DB) March 11, 2015

Thomas A. Mattee ('08, WW) Jan. 22, 2015

Other

Shawn R. Adelgren (Student, PC) May 2, 2015 March 19, 2015 


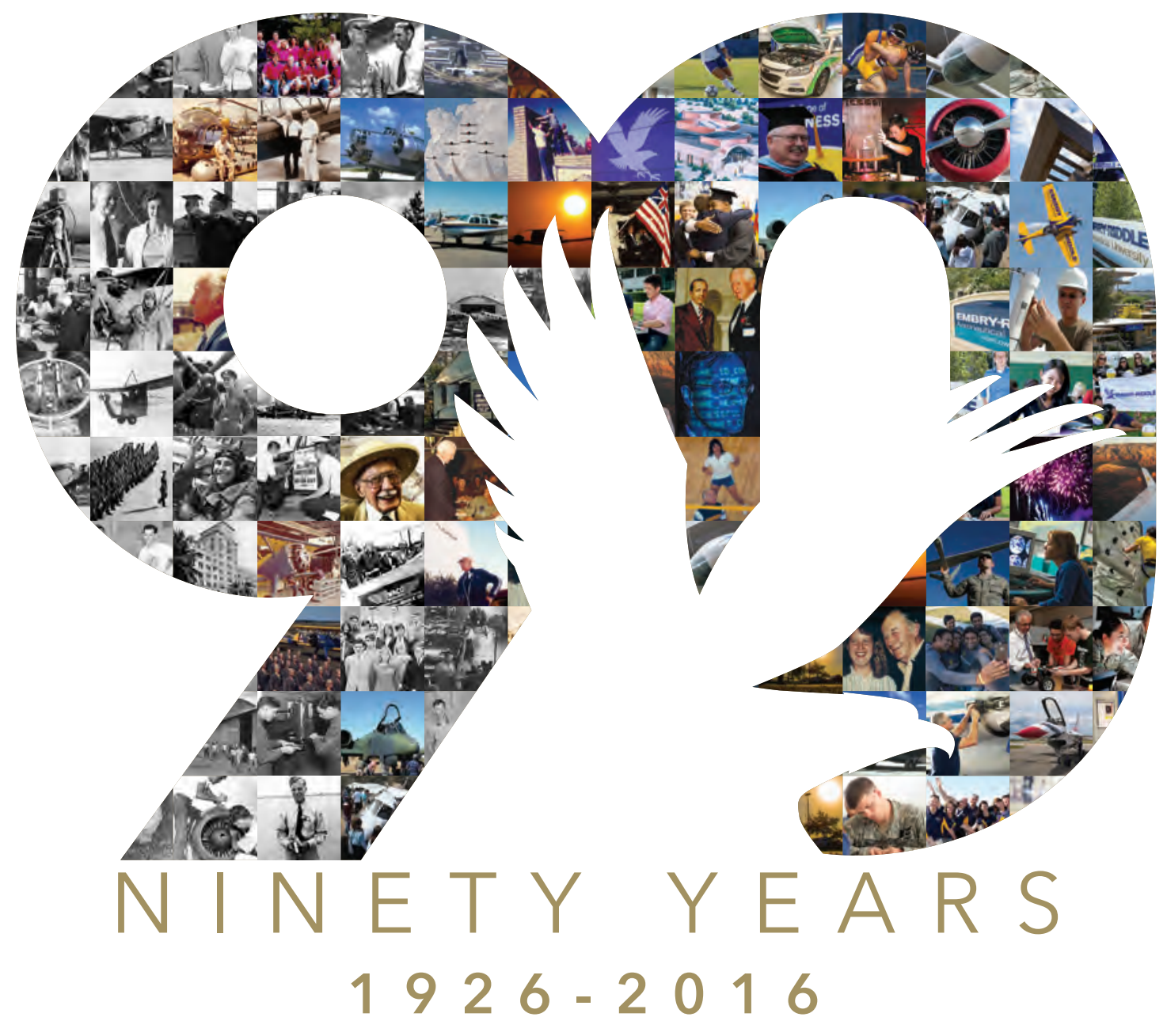

EMBRYRIDDLE Aeronautical University FLORIDA | ARIZONA | WORLDWIDE

givingto.erau.edu/90
For over 90 years, the alumni of Embry-Riddle, now more than 120,000 strong, have been driving innovation to push the envelope for what is possible in aviation and aerospace.

As one of those alumni, you have a unique opportunity to commemorate your university's 90th anniversary while investing in its future.

Go to givingto.erau.edu/90 to find out how you can help elevate Embry-Riddle for generations to come. 